Prepared in cooperation with Northern Arizona University and Utah State University

\title{
Sandbar Response in Marble and Grand Canyons, Arizona, Following the 2008 High-Flow Experiment on the Colorado River
}

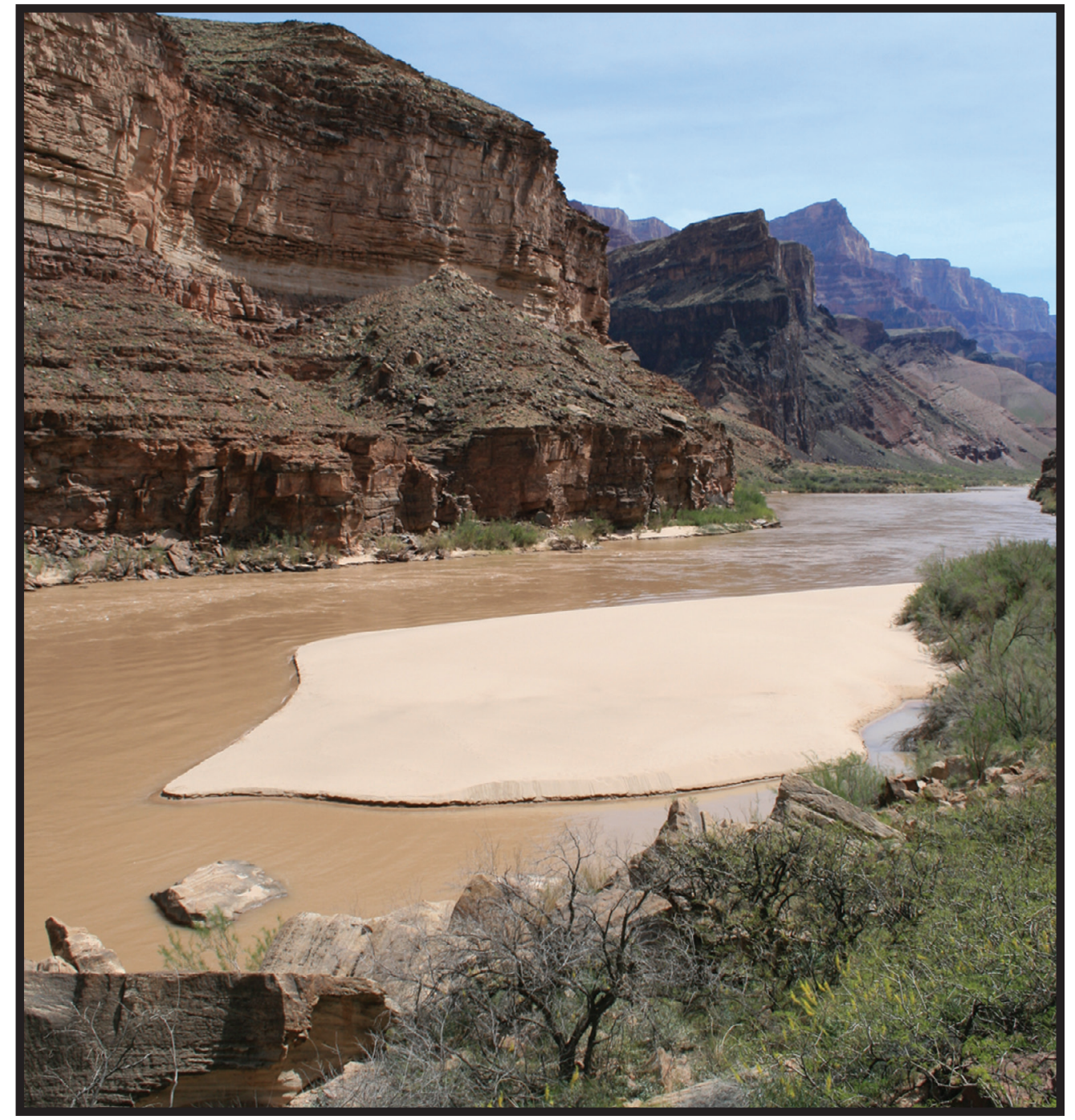

Scientific Investigation Report 2010-5015

U.S. Department of the Interior

U.S. Geological Survey 
COVER:

View looking south (downstream) of the Colorado River and the sandbar at Carbon Canyon (study site 65R in Eastern Grand Canyon) on April 4, 2008. Discharge at the time was about $368 \mathrm{~m}^{3} / \mathrm{s}$. (Photograph by J.E. Hazel, Jr.) 


\section{Sandbar Response in Marble and Grand Canyons, Arizona, Following the 2008 High-Flow Experiment on the Colorado River}

By Joseph E. Hazel, Jr., Paul E. Grams, John C. Schmidt, and Matt Kaplinski

Prepared in cooperation with Northern Arizona University and Utah State University

Scientific Investigations Report 2010-5051 


\section{U.S. Department of the Interior \\ KEN SALAZAR, Secretary}

\section{U.S. Geological Survey \\ Marcia K. McNutt, Director}

\section{U.S. Geological Survey, Reston, Virginia 2010}

For product and ordering information:

This report and any updates to it are available online at:

http://pubs.usgs.gov/sir/2010/5015/

World Wide Web: http://www.usgs.gov/pubprod

Telephone: 1-888-ASK-USGS (1-888-275-8747)

For more information on the USGS - the Federal source for science about the Earth, its natural and living resources, natural hazards, and the environment:

World Wide Web: http://www.usgs.gov/

Telephone: 1-888-ASK-USGS (1-888-275-8747)

Although this report is in the public domain, permission must be secured from the individual copyright owners to reproduce any copyrighted material contained within this report.

Any use of trade, product, or firm names is for descriptive purposes only and does not imply endorsement by the U.S. Government.

Suggested citation:

Hazel, J.E., J r., Grams, P.E., Schmidt, J.C., and Kaplinski, M., 2010, Sandbar response in Marble and Grand Canyons, Arizona, following the 2008 high-flow experiment on the Colorado River: U.S. Geological Survey Scientific Investigations Report 2010-5015, 52 p. 


\section{Contents}

Abstract
Introduction
Purpose and Scope
Physical Setting.
Units, Place Names, and Study Area
The Fan-Eddy Complex
Controlled Floods, Tributary Sand Inputs, and Fluctuating Flows
Results
Overview of Topographic Response
$\quad$ Styles of Topographic Response 1 2 With Net Eddy Erosion
$\quad$ Style 2 With Net Eddy Deposition
$\quad$ Style 3 .

\section{Figures}

1. The Colorado River and Grand Canyon National Park, between Lake Powell and Lake Mead reservoirs.

2. Geomorphic description of physical setting and boundary definitions for fan-eddy complexes of the Colorado River......................................................................

3. Instantaneous discharge of the Colorado River at USGS streamflow-gaging station (09380000), Lees Ferry, Arizona, for the 2008 calendar year .............................

4. Histograms of net sandbar thickness change between February and April 2008 ...............13

5. Relation of proportional sand-volume change above reference stage for each site between February and April 2008 .........................................................14

6. Comparison of repeat topographic and bathymetric surveys collected

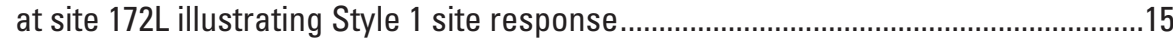

7. Selected daily photographs of the reattachment bar at site 172L.......................................16 
8. Areal and volumetric elevation-change distributions from the erosion-deposition map at site $172 \mathrm{~L}$ shown in figure $6 \mathrm{C}$.

9. Comparison of repeat topographic and bathymetric surveys collected at site 44L illustrating a Style 2 sandbar response

10. Selected daily photographs of the sandbars at site 44L

11. Areal and volumetric elevation-change distributions from the erosion-deposition map at site $44 \mathrm{~L}$ shown in figure $9 \mathrm{C}$

12. Comparison of repeat topographic and bathymetric surveys collected at 65R illustrating a variant of Style 2 response.

13. Selected daily photographs of the reattachment bar at site $65 R$

14. Areal and volumetric elevation-change distributions from the erosion-deposition map at site $65 \mathrm{R}$ shown in figure $12 \mathrm{C}$.

15. Comparison of repeat topographic and bathymetric surveys collected at site $3 \mathrm{~L}$.............25

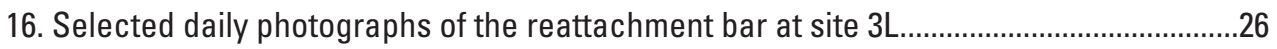

17. Areal and volumetric elevation-change distributions from the erosion-deposition map at site $3 \mathrm{~L}$ shown in figure $15 \mathrm{C}$

18. Downstream variations at study sites and sediment-transport-flux monitoring reaches in response to $2008 \mathrm{HFE}$

19. Photographic sequence at site $68 \mathrm{R}$ showing rapid erosion following the change in fluctuating flow regime at Glen Canyon Dam on April 15, 2008

20. Boxplot showing temporal sequence of deposit thickness above the reference stage compared to daily mean discharge following the $2008 \mathrm{HFE} . . . .29$

21. Histograms showing the distribution of campsite area above the reference stage

22. Average campsite area above the reference stage before, after, and about 6 months after the $2008 \mathrm{HFE}$

23. The relation of change in campsite area to change in sandbar area and volume for two time intervals in 2008, pre- to postflood (February-April) and the following 6 months (April-October)

24. Cumulative probability distributions of total-site sand volume following the 1996, 2004, and 2008 HFEs.

25. Boxplots showing normalized sand volumes of all sites within each sediment-transport-flux monitoring reach.

26. Cumulative probability distributions of sand volume above reference stage following the 1996, 2004, and $2008 \mathrm{HFEs}$ 


\section{Tables}

1. Channel geometry and geomorphic characteristics for selected study sites, Colorado River in Marble and Grand Canyons ............................................................ 6

2. Sediment-transport-flux monitoring stations and reaches of the Colorado River used to compare the 1996, 2004, and 2008 HFEs.....................................................11

3. Critical and noncritical recreational campsite reaches

of the Colorado River...

4. Observations of erosion and deposition from repeat photography at sites along the Colorado River in Marble and Grand Canyons.

Table B1. High-elevation-zone area and volume at four measurement times in 2008

at each study site. . .46

Table B2. Midelevation zone area and volume at four measurement times in 2008 at each study site

Table B3. Low-elevation-zone eddy area and volume, and main-channel volume at four measurement times in 2008 at each study site

Table B4. Midelevation zone and high-elevation-zone campsite area measured at four measurement times in 2008 at each study site 


\section{Conversion Factors}

\section{Inch/Pound to SI}

\begin{tabular}{lcc}
\hline Multiply & By & To obtain \\
\hline & Length & \\
\hline mile $(\mathrm{mi})$ & 1.609 & kilometer $(\mathrm{km})$ \\
\hline
\end{tabular}

\section{SI to Inch/Pound}

\begin{tabular}{lcc}
\hline Multiply & By & To obtain \\
\hline meter $(\mathrm{m})$ & Length & foot $(\mathrm{ft})$ \\
\hline & 3.281 & \\
\hline square meter $\left(\mathrm{m}^{2}\right)$ & Area & square foot $\left(\mathrm{ft}^{2}\right)$ \\
\hline & 10.76 & \\
\hline cubic meter $\left(\mathrm{m}^{3}\right)$ & Volume & cubic foot $\left(\mathrm{ft}^{3}\right)$ \\
\hline & 35.31 & \\
\hline metric ton $(\mathrm{t})$ & Mass & ton $(2,000 \mathrm{lb})$ \\
\hline & 1.102 & \\
\hline cubic meter per second $\left(\mathrm{m}^{3} / \mathrm{s}\right)$ & Flow rate & cubic foot per $\mathrm{second}\left(\mathrm{ft}^{3} / \mathrm{s}\right)$ \\
\hline
\end{tabular}

In this report, horizontal and vertical coordinate information is referenced in meters above the GRS80 ellipse defined by the North American Datum of 1983 (NAD 83). Elevation, as used in this report, refers to NAD83/GRS80 ellipsoid heights and not traditionally defined NAVD88 orthometric heights. 


\title{
Sandbar Response in Marble and Grand Canyons, Arizona, Following the 2008 High-Flow Experiment on the Colorado River
}

\author{
By Joseph E. Hazel, Jr.', Paul E. Grams ${ }^{2}$, John C. Schmidt ${ }^{3}$, and Matt Kaplinski'
}

\section{Abstract}

A 60-hour release of water at 1,203 cubic meters per second $\left(\mathrm{m}^{3} / \mathrm{s}\right)$ from Glen Canyon Dam in March 2008 provided an opportunity to analyze channel-margin response at discharge levels above the normal, diurnally fluctuating releases for hydropower plant operations. We compare measurements at sandbars and associated campsites along the mainstem Colorado River, downstream from Glen Canyon Dam, at 57 locations in Marble and Grand Canyons. Sandbar and main-channel response to the 2008 high-flow experiment (2008 HFE) was documented by measuring bar and bed topography at the study sites before and after the controlled flood and twice more in the following 6 months to examine the persistence of flood-formed deposits. The $2008 \mathrm{HFE}$ caused widespread deposition at elevations above the stage equivalent to a flow rate of $227 \mathrm{~m}^{3} / \mathrm{s}$ and caused an increase in the area and volume of the high-elevation parts of sandbars, thereby increasing the size of campsite areas. In this study, we differentiate between four response styles, depending on how sediment was distributed throughout each study site. Then, we present the longitudinal pattern relevant to the different response styles and place the site responses in context with two previous highrelease experiments conducted in 1996 and 2004. We find that (1) nearly every measured sandbar aggraded above the 227$\mathrm{m}^{3} / \mathrm{s}$ water-surface elevation, resulting in sandbars as large or larger than occurred following previous high flows; (2) reaches closest to Glen Canyon Dam were characterized by a greater percentage of sites that incurred net erosion, although the total sand volume in all sediment-flux monitoring reaches was greater following the $2008 \mathrm{HFE}$ than following previous high flows; and (3) longitudinal differences in topographic response

${ }^{1}$ Northern Arizona University, School of Earth ScienceVand Environmental Sustainability, Flagstaff, Arizona

${ }^{2}$ U.S. Geological Survey, Southwest Biological Science Center, Grand Canyon Monitoring and Research Center, Flagstaff, Arizona

${ }^{3}$ Utah State University, Department of Aquatic, Watershed, and Earth Resources, Logan, Utah in eddies and in the channel suggest a greater and more evenly distributed sediment supply than existed during previous controlled floods from Glen Canyon Dam.

\section{Introduction}

Operations of Glen Canyon Dam affect the downstream geomorphology and associated riverine ecosystem along the Colorado River in Marble and Grand Canyons (fig. 1). One feature of the geomorphic environment is the sand and finer sediment that occurs as eddy bars, channel-margin deposits, and as patches that cover parts of the coarser grained channel bed. These deposits are of interest, because sandbars are an attribute of the pre-dam riverine landscape, are used as campsites, are substrate for riparian plants, create aquatic habitat, and are a source of windblown sand that potentially buries and preserves archaeological sites (Wright and others, 2005; Draut and Rubin, 2008).

Completion of Glen Canyon Dam in 1963 eliminated the supply of fine sediment delivered from the upper Colorado River Basin, decreased the magnitude of annual flood flows, and increased the magnitude of base flows (Howard and Dolan, 1981; Topping and others, 2003; Wright and others, 2005). Collectively, these changes in hydrology and sediment supply caused evacuation of sand from the bed and margins of the river channel, such that the average size of sandbars emergent at base flows in 2001 was at least 25 percent less than before completion of the dam (Schmidt and others, 2004). Other factors, such as vegetation growth (Turner and Karpiscak, 1980), hillslope runoff or burial by debris flows (Melis and others, 1994), eolian processes (Draut and Rubin, 2008), and human activities (Phillips and others, 1986) have also contributed to reductions in the area of exposed bare sand, thereby reducing the area available for camping (Kearsley and others, 1994; Kaplinski and others, 2005).

The Colorado River in Marble and Grand Canyons is currently the subject of a large-scale river rehabilitation program called the Glen Canyon Dam Adaptive Management Program (GCDAMP). A primary goal of the GCDAMP is to maintain or improve the condition of sandbars for their associated 


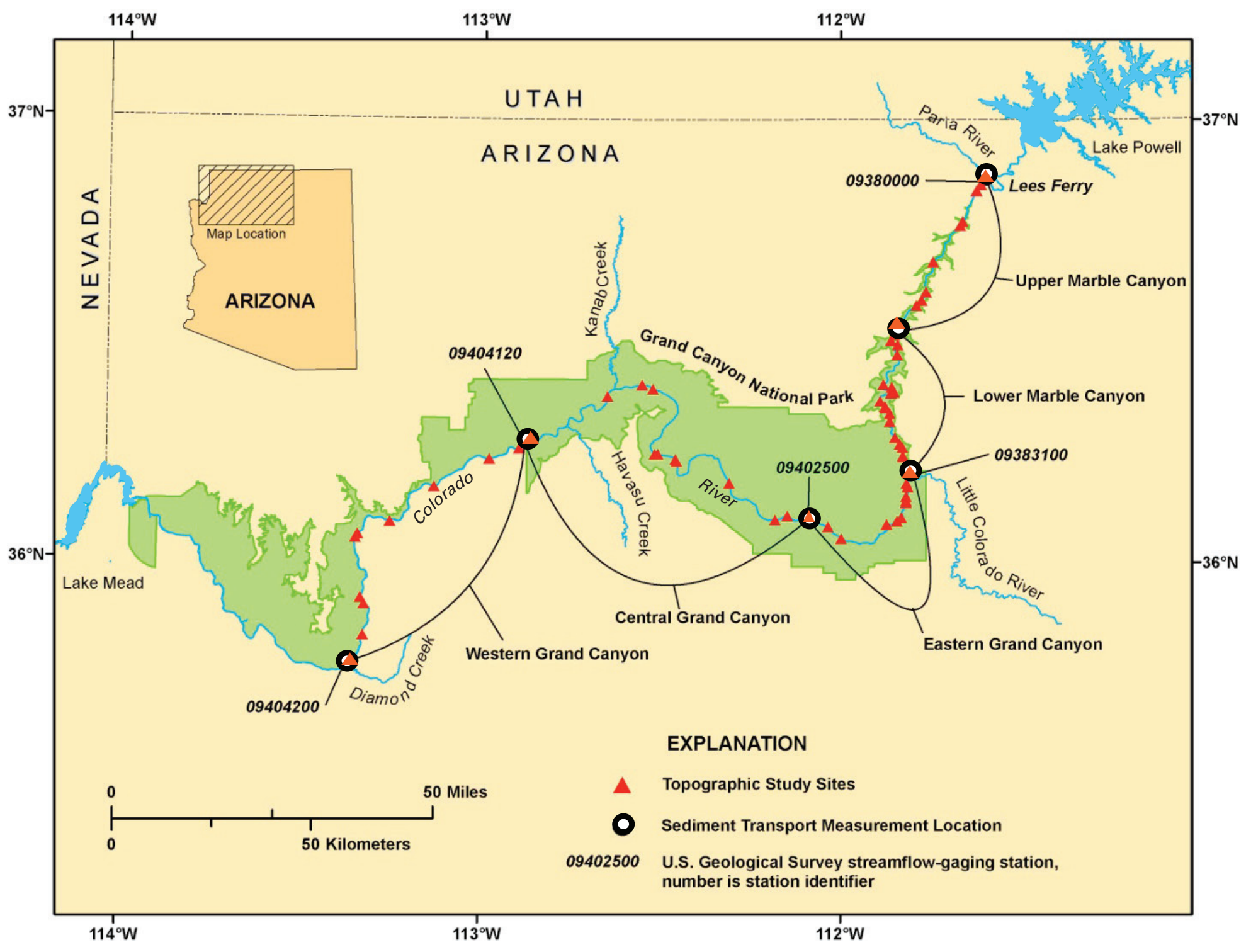

Figure 1. The Colorado River and Grand Canyon National Park, between Lake Powell and Lake Mead reservoirs. Shown are the locations of Lees Ferry, the topographic survey sites, U.S. Geological Survey gaging stations (with station numbers), and the sediment-transport flux monitoring reaches between the sediment-transport measurement sites. 
ecosystem and resource values (U.S. Department of Interior, 1995; National Research Council, 1999). One aspect of the GCDAMP is implementation of an experimental program that evaluates the environmental effects of dam releases (Patten and others, 2001; Wright and others, 2005). On March 6, 2008, a 2.5-day (60-hour) controlled flood of 1,203 cubic meters per second $\left(\mathrm{m}^{3} / \mathrm{s}\right)$ was released from Glen Canyon Dam (U.S. Department of Interior, 2008). At the time of this release, the river bed had been supplied with fine sediment (sand, silt, and clay) by a series of floods from the Paria River (fig. 1) in fall 2006 and fall 2007 . The purpose of the present study is to document the response of eddy bars and some of the associated resource attributes to this flood, termed the 2008 highflow experiment (2008 HFE). The findings are compared to results from two previous high-flow experiments conducted under differing sand-supply and flow conditions: the longer duration $1996 \mathrm{HFE}$ of $1,275 \mathrm{~m}^{3} / \mathrm{s}$ (Webb and others, 1999) and the 2004 HFE of similar magnitude and duration as the 2008 HFE (Topping and others, 2006a).

\section{Purpose and Scope}

The principal goals of this study are: (1) evaluation of whether sandbars located throughout the Colorado River in Marble and Grand Canyons gained or lost sand in response to the $2008 \mathrm{HFE}$, (2) evaluation of the persistence of rebuilt sandbars under normal dam operations over the 6-month period that followed the $2008 \mathrm{HFE}$, (3) comparison of the river response to the $2008 \mathrm{HFE}$ with the river response to the 1996 and 2004 high flows at common monitoring sites, and (4) evaluation of changes in the area of campsites associated with sandbar changes resulting from the 2008 HFE. Site response was analyzed above and below the $227-\mathrm{m}^{3} / \mathrm{s}$ water-surface elevation (hereafter referred to as the reference stage; sand below this elevation is almost always subaqueous, while sand above this elevation is either always subaerial or within the diurnal fluctuating zone of dam releases associated with peaking hydropower generation). In order to facilitate comparison with data collected during the two previous HFEs, detailed field measurements were made at the long-term study sites measured by Hazel and others (1999) and Kaplinski and others (2005), as well as additional sites, on five survey trips in 2008.

\section{Physical Setting}

\section{Units, Place Names, and Study Area}

Measurements are reported in the SI system; however, locations and place names are reported in river miles (RM), downstream from Lees Ferry, Arizona (RM 0). The rivermile convention has long been used as the standard reference system for locations along the Colorado River in Marble and Grand Canyons and was formalized in 2006 (U.S. Geological Survey, 2006). Lees Ferry is located 15.5 miles downstream from Glen Canyon Dam and 1 mile upstream from the mouth of the Paria River and the northeastern boundary of Grand Canyon National Park (fig. 1).

In this report, we refer to Marble Canyon as the reach of the Colorado River between the Paria River and the Little Colorado River, located at RM 61.5 (fig. 1). The Paria River is the primary source of sand to the upstream end of Marble Canyon (Topping and others, 2000). Although Grand Canyon extends downstream to the Grand Wash Cliffs (RM 276), for our purposes we refer to Grand Canyon as the segment downstream from the Little Colorado River and extending to Diamond Creek (RM 226). Place names were derived from Stevens (1990) and Belknap (2001). The "left" and "right" sides of the Colorado River are with respect to assuming the viewer is facing in a downstream direction.

For evaluation of downstream variations in response to the $2008 \mathrm{HFE}$, we defined five sediment-transport-flux monitoring reaches in Marble and Grand Canyons (fig. 1; table 2). These reaches are demarcated by locations at which tributary sediment inputs occur or mainstem bed sediment, suspendedsediment concentration, and grain size are monitored (Topping and others, 2006b). The fixed sediment-transport measurement sites are: (1) the Colorado River at Lees Ferry gaging station (USGS station number 09380000; RM 0), (2) the RM 30 sediment station, located at the midpoint of Marble Canyon, (3) the Colorado River above Little Colorado River near Desert View gaging station (gage was discontinued) (09383100; RM 61), (4) the Colorado River near Grand Canyon gaging station (09402500; RM 88), (5) the former Colorado River above National Canyon near Supai gaging station (09404120; RM167), and (6) the Colorado River above Diamond Creek near Peach Springs gaging station (09404200; RM 225). In the downstream order in which they occur, we refer to the sediment-transport-flux monitoring reaches as upper Marble Canyon (UMC), lower Marble Canyon (LMC), eastern Grand Canyon (EGC), central Grand Canyon (CGC), and western Grand Canyon (WGC).

\section{The Fan-Eddy Complex}

The geomorphic framework of the Colorado River in Marble and Grand Canyons is dominated by an assemblage of channel features termed the fan-eddy complex by Schmidt and Rubin (1995). Debris flows and floods in steep, ephemeral tributaries to the Colorado River deliver large boulders to the Colorado River, some of which cannot be transported by the mainstem (Webb and others, 1989). The bouldery deposits create debris fans that constrict the mainstem channel flow and create rapids (fig. $2 A$ ). These hydraulic controls define the longitudinal profile of the river and affect flow patterns immediately upstream and downstream from each debris fan (Howard and Dolan, 1981). Immediately upstream from each debris fan is an area of ponded flow, where flow has decelerated, stage has increased, and water-surface slope has decreased so as to create sufficient potential energy to accelerate flow through the constriction, analogous to flow from a 
nozzle (Kieffer, 1985). The area of ponded flow may extend upstream a few channel widths to a few kilometers and varies with discharge. Immediately downstream from each debris fan, channel width typically is wider than elsewhere (Schmidt, 1990). Cross-sectional area here is much greater than in the rapid, because channel depth also increases greatly. Much of the increase in depth occurs where a deep scour hole typically develops immediately downstream from the rapid (fig. $2 A$ ). Lateral recirculating eddies typically form between the boundary of the downstream flowing jet and the channel banks (Schmidt, 1990). Further downstream from the scour hole and lateral recirculating eddies, the channel typically narrows and shallows; this portion of the bed is referred to as the exit slope (fig. $2 A$ ). The acceleration of stream flow associated with the slight decrease in channel cross-sectional area terminates the downstream length of eddies along the channel banks. A midchannel or bank-attached cobble bar commonly occurs in these areas of somewhat shallow flow. The coarse debris is the result of erosion of the upstream debris fan during pre-dam high flows (Webb and others, 1989). At lower discharges, flow typically passes around the margins of these cobble bars and creates a riffle (fig. $2 A$ ).

Each of the sites selected to study 2008 HFE sandbar response is in the channel expansion immediately downstream
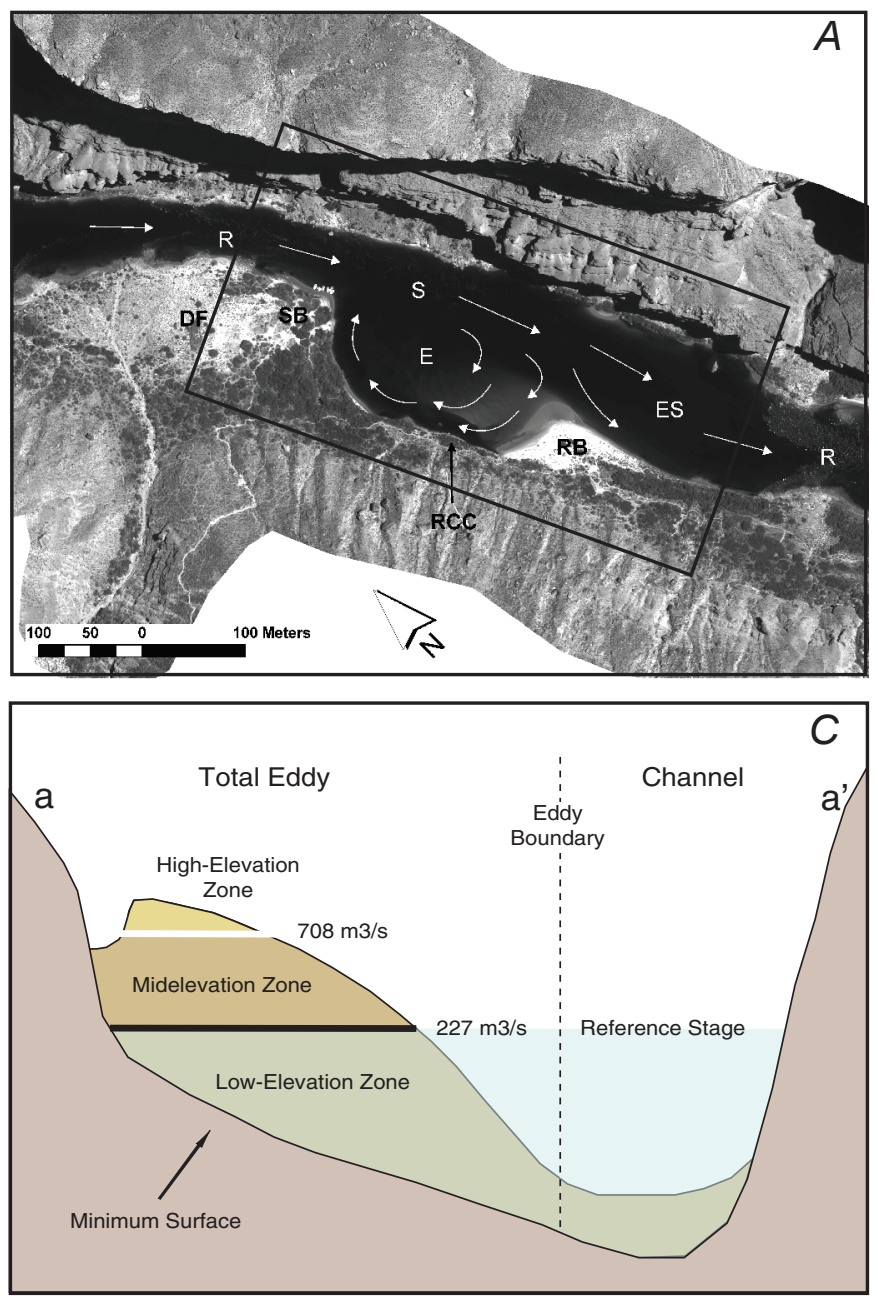

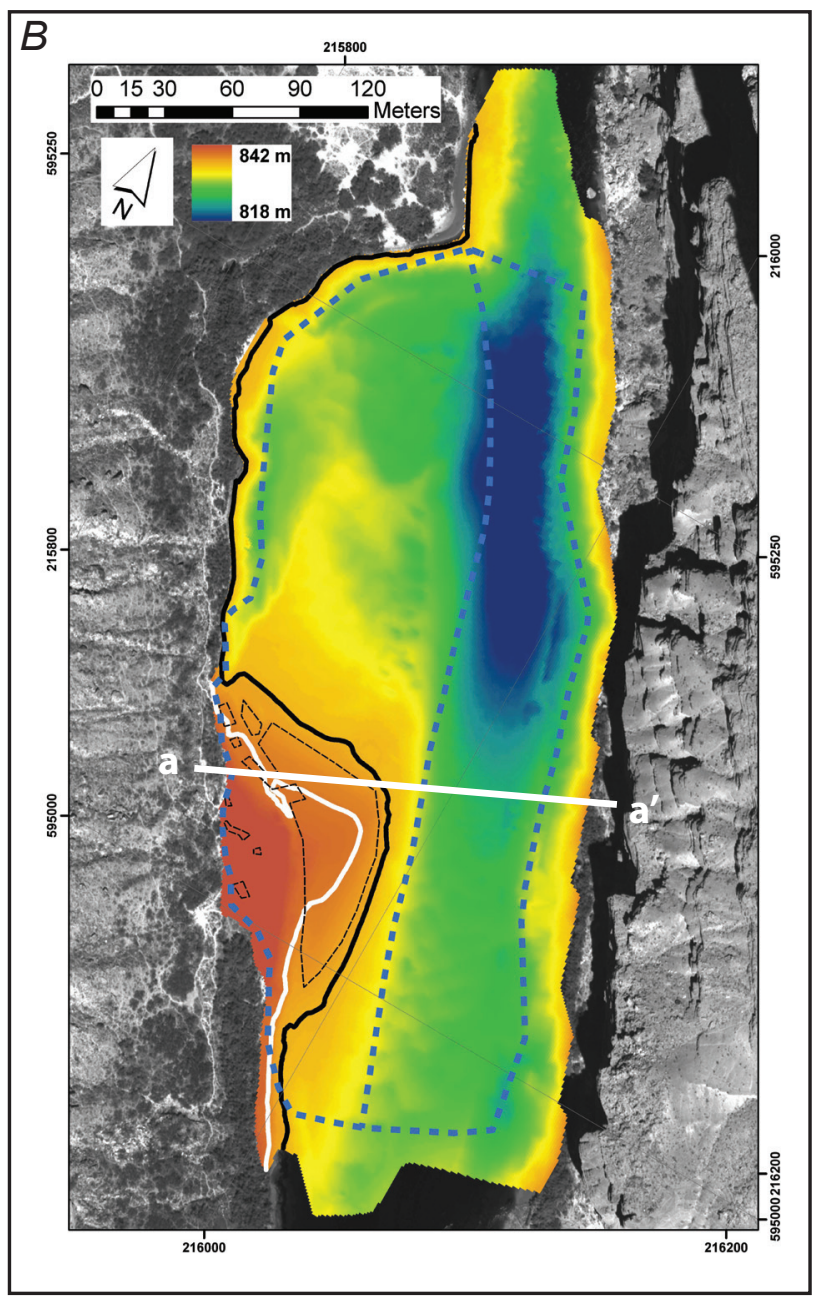

Figure 2. Geomorphic description of physical setting and boundary definitions for fan-eddy complexes of the Colorado River. $A$, Aerial view (May 2002) of a typical fan-eddy complex (listed in table 1 as site 47R) in Marble Canyon at the reference stage $\left(227 \mathrm{~m}^{3} / \mathrm{s}\right)$. DF, tributary debris fan; $R$, rapid or riffle; $S$, scour hole; $E S$, exit slope; $E$, eddy; RB, reattachment bar; $S B$, separation bar, RCC, return-current channel. Arrows indicate flow direction. Box insert indicates area shown in $B$. $B$, Digital elevation model (1983 Arizona State Plane in meters, central zone projection) of the same site from the April 1, 2008, survey. The dashed blue line is the computational boundary for the channel expansion, with a dividing line between the eddy and main channel. The solid black and white lines are the stage elevations reached by flows of $227 \mathrm{~m} / \mathrm{s}$ and $708 \mathrm{~m}^{3} / \mathrm{s}$, respectively. These stage elevations separate high-elevation, midelevation, and low-elevation zones within the total eddy. The thin dashed black lines show the surveyed campsite area. Heavy white line is approximate location of schematic cross section a-a' shown in $C$. $C$, Schematic of computational boundaries in a- $\mathrm{a}^{\prime}$ described in the text. Note that a- $\mathrm{a}^{\prime}$ is viewed in an upstream direction. 
from the rapid. All sites include the entire bed of the lateral recirculating eddy, and most sites include the bed of the adjacent channel, where the predominant direction of flow is downstream. Although debris fans may become overtopped at high discharges, causing regions of recirculating flow to shrink and eventually disappear, all sites included in this study were eddies with recirculating flow across the full range of discharges that occurred during the study period.

Lower flow velocities in eddies promote deposition from the suspended load. Eddies have the potential to completely fill with sediment (Wiele and others, 1996) and can contain sandbars more than $10 \mathrm{~m}$ thick (Rubin and others, 1994). The scour hole and main-channel bed adjacent to eddies may be completely covered with sand, forming subaqueous dune fields 1 to $2 \mathrm{~m}$ thick in some locations, while in other locations the bed-sand area is patchy over large regions of the gravel, boulder, and bedrock bed (Anima and others, 1998; Howard and Dolan, 1981; Wilson, 1986; Schmidt and others, 2007; D. Topping, U.S. Geological Survey, written commun., 2009). Much thicker sand deposits, however, can temporarily accumulate in the main channel during tributary flooding (Wiele and others, 1996).

Sand deposits in eddies have been described and classified by Schmidt (1990) as separation bars, which form near the upstream part of the eddy where flow separates from the bank, and reattachment bars, which form where flow reattaches to the bank (fig. 2A). Separation bars mantle the downstream surface of debris fans, but they do not exist downstream from all debris fans. Reattachment bars form a platform projecting upstream into the center of the eddy. A distinct geomorphic characteristic of reattachment bars is the return-current channel, where upstream-directed flow is redirected along the bank (Rubin and others, 1990). This deep channel typically divides the separation bar from the reattachment bar. At lower flows, the return-current channel becomes stagnant as recirculating flow is partially blocked by an emergent reattachment bar. This low-velocity condition can result in suitable habitat for certain native fish (Korman and others, 2004; Schmidt and others, 2007). We use the term "eddy bar" where the unique topography of separation bars and reattachment bars cannot be distinguished or where the distinction is not relevant to the discussion (table 1).

\section{Controlled Floods, Tributary Sand Inputs, and Fluctuating Flows}

The 2008 HFE was the third controlled flood released from Glen Canyon Dam with the intention of rebuilding sandbars. The first such experimental flow occurred in 1996 and consisted of a 7-day release of $1,275 \mathrm{~m}^{3} / \mathrm{s}$ (see Webb and others, 1999, for details on the 1996 HFE). Sandbar surveys and photographic analyses indicated that sediment was deposited on the channel margin as high-elevation sandbars but that low-elevation sandbars were eroded (Hazel and others, 1999; Andrews and others, 1999; Schmidt and others, 1999).
Sandbar deposits formed by the 1996 HFE exhibited upwardcoarsening grain size, indicating that the supply of fine sediment was exhausted during the course of the event (Rubin and others, 1998). This finding was supported by sediment budgets constructed for the 1996 high flow that showed eddies were the source for much of the suspended sediment, rather than the sandy bed of the main channel (Schmidt and others, 1999; Hazel and others, 2006a). On the basis of the 1996 findings, researchers concluded that future high-flow experiments should only be conducted under conditions of enriched sand supply such that high flows would result in sandbar deposition, without depleting sand from storage as occurred in 1996 (Rubin and others, 2002).

This concept of sand-enriched high flows was first tested by the second high flow, conducted in November 2004, which was timed to follow a period of sand delivery from the Paria River. Because findings from the 1996 HFE indicated that most deposition occurred in the initial 1 to 2 days of that experiment (Andrews and others, 1999; Schmidt and others, 1999), and on the basis of later sandbar simulations conducted by Wiele and Torrizo (2005) with flow and sandsupply boundary conditions similar to those measured during the $1996 \mathrm{HFE}$, the $2004 \mathrm{HFE}$ was shorter in duration (2.5 days) and had a slightly smaller peak discharge $\left(1,160 \mathrm{~m}^{3} / \mathrm{s}\right)$. This experiment resulted in an increase of total sandbar area and volume in the upper end of Grand Canyon, but further downstream, where sand accumulation had not occurred, there was a net transfer of sand out of eddies (Topping and others, 2006a). Topping and others (2006a) concluded that in order to achieve increases in total sandbar area and volume throughout a greater proportion of Marble and Grand Canyons, more sand would be required than was available during the 2004 high flow.

The 2008 HFE was released specifically to test the hypothesis that greater antecedent sand supply could result in sandbar building throughout most of Marble and Grand Canyons without depleting more sand than was accumulated by tributary inputs leading up to the event (Topping and others, 2006a). Tributary floods in the Paria River, primarly in October 2006 and August-September 2007, supplied about $3.35 \pm 0.34$ million metric tons of sand to the Colorado River between the 2004 and 2008 HFEs (D. Topping, U.S. Geological Survey, written commun., 2009). As a result, Marble Canyon contained approximately two to three times more sand than had accumulated before the 2004 high-flow release. In contrast, the year antecedent to the 1996 HFE had the least recorded accumulation of tributary-supplied sand in the Colorado River in Marble and Grand Canyons (D. Topping, U.S. Geological Survey, written commun., 2009).

The 2008 HFE had a similar hydrograph as the 2004 high-flow hydrograph (fig. 3). Beginning on March 4, 2008, releases were increased by $43 \mathrm{~m}^{3} / \mathrm{s}$ per hour until hydropower plant capacity $\left(892 \mathrm{~m}^{3} / \mathrm{s}\right)$ was reached, and then each of the four Glen Canyon Dam bypass tubes was opened for a total bypass release of $425 \mathrm{~m}^{3} / \mathrm{s}$ by March 6 (U.S. Department of the Interior, 2008). For the 60-hour period that discharge 
Table 1. Channel geometry and geomorphic characteristics for selected study sites, Colorado River in Marble and Grand Canyons.

[Site names are from Belknap (2001) and Stevens (1990) or are informally used. **, sites surveyed before and after the 1996 and 2004 HFEs. *, sites surveyed before and after the 1996 HFE. -, not determined because bathymetry data were not collected at the site.]

\begin{tabular}{|c|c|c|c|c|c|c|c|}
\hline \multirow{2}{*}{$\begin{array}{l}\text { Site } \\
\text { ID }^{1}\end{array}$} & \multirow{2}{*}{$\begin{array}{l}\text { River } \\
\text { Mile } \\
(\text { RM) }\end{array}$} & \multirow{2}{*}{ Site Name } & \multirow{2}{*}{$\begin{array}{c}\text { Deposit } \\
\text { Type }^{3}\end{array}$} & \multirow{2}{*}{$\begin{array}{l}\text { Eddy } \\
\text { Size } \\
\left(\mathrm{m}^{2}\right)^{4}\end{array}$} & \multicolumn{2}{|c|}{ Expansion Ratio ${ }^{5}$} & \multirow{2}{*}{$\begin{array}{c}\text { Stage } \\
\text { Change }^{6} \\
\text { (m) }\end{array}$} \\
\hline & & & & & $\begin{array}{c}242 \\
\left(\mathrm{~m}^{3} / \mathrm{s}\right)\end{array}$ & $\begin{array}{l}1,203 \\
\left(\mathrm{~m}^{3} / \mathrm{s}\right)\end{array}$ & \\
\hline $1 \mathrm{R}$ & 1.2 & Paria Beach & $\mathrm{U}$ & 40,880 & 2.0 & 1.5 & 3.0 \\
\hline $3 \mathrm{~L} * *$ & 2.5 & Cathedral Wash & $\mathrm{R}$ & 7,610 & 1.5 & 1.3 & 3.4 \\
\hline $8 \mathrm{~L} * *$ & 8.1 & Below Jackass & $\mathrm{S}$ & - & 1.6 & 1.5 & 3.0 \\
\hline $9 \mathrm{~L}$ & 8.9 & & $\mathrm{~S}, \mathrm{R}$ & 12,270 & 1.8 & 1.4 & 4.2 \\
\hline $16 \mathrm{~L}^{* *}$ & 16.6 & Hot $\mathrm{Na} \mathrm{Na}$ Wash & $\mathrm{S}$ & 8,160 & 2.1 & 1.2 & 3.1 \\
\hline $22 \mathrm{R} * *$ & 22.0 & Twentytwo Mile & $\mathrm{R}$ & 7,160 & 1.5 & 1.5 & 5.8 \\
\hline $24 \mathrm{~L}$ & 23.6 & Lone Cedar & $\mathrm{U}$ & - & 1.3 & 1.4 & 5.0 \\
\hline $29 \mathrm{~L}$ & 29.5 & Shinumuo Wash & $\mathrm{U}$ & - & 1.2 & 1.0 & 4.8 \\
\hline $30 \mathrm{R}^{* *}$ & 30.7 & Sand Pile & $\mathrm{R}$ & 8,520 & 1.7 & 1.6 & 5.0 \\
\hline $32 \mathrm{R}^{* *}$ & 31.9 & South Canyon & $\mathrm{U}$ & 11,620 & 2.8 & 1.5 & 2.9 \\
\hline $33 \mathrm{~L}$ & 33.3 & Redwall Cavern & $\mathrm{R}$ & - & - & - & 4.7 \\
\hline $35 \mathrm{~L}$ & 35.1 & Nautiloid & $\mathrm{S}, \mathrm{R}$ & 21,390 & 2.5 & 1.4 & 5.0 \\
\hline $41 \mathrm{R}$ & 41.4 & Buck Farm & $\mathrm{S}, \mathrm{R}$ & 42,050 & 2.9 & 1.7 & 4.1 \\
\hline $43 L^{* *}$ & 43.4 & Anasazi Bridge & $\mathrm{R}$ & 8,460 & 1.7 & 1.3 & 4.3 \\
\hline $44 \mathrm{~L} * *$ & 44.6 & Eminence & $\mathrm{S}, \mathrm{R}$ & 26,570 & 1.9 & 1.4 & 4.1 \\
\hline $45 \mathrm{~L}$ & 45.0 & $\begin{array}{l}\text { Willie Taylor } \\
\text { Camp }\end{array}$ & $\mathrm{S}, \mathrm{R}$ & 22,550 & 1.9 & 1.4 & 4.0 \\
\hline $47 \mathrm{R}^{* *}$ & 47.6 & Lower Saddle & $\mathrm{R}$ & 28,440 & 2.6 & 1.9 & 3.5 \\
\hline $49 \mathrm{R}$ & 48.8 & & $\mathrm{R}$ & 7,640 & 1.4 & 1.3 & 3.8 \\
\hline $49 \mathrm{~L}$ & 48.9 & & $\mathrm{~S}, \mathrm{R}$ & 14,470 & 1.4 & 1.2 & 3.8 \\
\hline $50 \mathrm{R}^{* *}$ & 50.2 & Dinosaur & $\mathrm{S}, \mathrm{R}$ & 8,691 & 1.0 & 1.0 & 3.9 \\
\hline $51 \mathrm{~L}^{* *}$ & 51.0 & $\begin{array}{l}\text { Fiftyone Mile } \\
\text { Camp }\end{array}$ & $\mathrm{R}$ & 31,690 & 1.6 & 1.5 & 3.5 \\
\hline $54 \mathrm{R}$ & 54.6 & & $\mathrm{R}$ & 12,370 & 1.4 & 1.4 & 3.4 \\
\hline $55 \mathrm{R}^{* *}$ & 55.9 & Kwagunt Marsh & $\mathrm{R}$ & 24,300 & 1.1 & 1.4 & 2.5 \\
\hline $56 \mathrm{R}$ & 56.6 & KwaguntBeach & $\mathrm{U}$ & - & 1.1 & 0.8 & 3.1 \\
\hline
\end{tabular}


Table 1. Channel geometry and geomorphic characteristics for selected study sites, Colorado River in Marble and Grand Canyons.-Continued

[Site names are from Belknap (2001) and Stevens (1990) or are informally used. **, sites surveyed before and after the 1996 and 2004 HFEs. *, sites surveyed before and after the 1996 HFE. -, not determined because bathymetry data were not collected at the site.]

\begin{tabular}{|c|c|c|c|c|c|c|c|}
\hline \multirow{2}{*}{$\begin{array}{l}\text { Site } \\
\text { ID' }\end{array}$} & \multirow{2}{*}{$\begin{array}{l}\text { River } \\
\text { Mile } \\
(\mathbf{R M})^{2}\end{array}$} & \multirow{2}{*}{ Site Name } & \multirow{2}{*}{$\begin{array}{c}\text { Deposit } \\
\text { Type }^{3}\end{array}$} & \multirow{2}{*}{$\begin{array}{l}\text { Eddy } \\
\text { Size } \\
\left(m^{2}\right)^{4}\end{array}$} & \multicolumn{2}{|c|}{ Expansion Ratio ${ }^{5}$} & \multirow{2}{*}{$\begin{array}{c}\text { Stage } \\
\text { Change }^{6} \\
\text { (m) }\end{array}$} \\
\hline & & & & & $\begin{array}{c}242 \\
\left(\mathrm{~m}^{3} / \mathrm{s}\right)\end{array}$ & $\begin{array}{l}1,203 \\
\left(\mathrm{~m}^{3} / \mathrm{s}\right)\end{array}$ & \\
\hline $58 \mathrm{~L}$ & 58.1 & Malgosa & $\mathrm{R}$ & - & 0.9 & 0.8 & 3.6 \\
\hline $62 \mathrm{R} * *$ & 62.9 & Crash Canyon & $\mathrm{R}$ & 15,920 & 1.7 & 1.4 & 3.9 \\
\hline $63 \mathrm{~L}^{* *}$ & 63.5 & & $\mathrm{~S}, \mathrm{R}$ & 27,870 & 3.0 & 2.1 & 4.0 \\
\hline $65 \mathrm{R}^{* *}$ & 65.2 & Carbon & $\mathrm{S}, \mathrm{R}$ & 17,130 & 1.6 & 1.2 & 2.8 \\
\hline $65 \mathrm{~L}$ & 65.8 & & $\mathrm{R}$ & 12,300 & 1.6 & 1.4 & 2.5 \\
\hline $66 \mathrm{~L}$ & 66.1 & Palisades Creek & $\mathrm{S}, \mathrm{R}$ & - & 1.8 & 1.4 & 2.0 \\
\hline $68 \mathrm{R} * *$ & 68.8 & Tanner & $\mathrm{U}$ & 15,950 & 1.2 & 1.1 & 2.4 \\
\hline $70 \mathrm{R}$ & 70.1 & Basalt & $\mathrm{R}$ & - & 2.0 & 1.7 & 2.7 \\
\hline $81 \mathrm{~L}^{* *}$ & 81.8 & Grapevine & $\mathrm{U}$ & 3,410 & 1.5 & 1.6 & 3.7 \\
\hline $84 \mathrm{R}$ & 84.6 & Clear Creek & $\mathrm{S}, \mathrm{R}$ & - & 1.3 & 1.3 & 4.9 \\
\hline $87 \mathrm{~L}^{* *}$ & 87.6 & Cremation & $\mathrm{U}$ & 1,150 & 1.5 & 1.1 & 3.8 \\
\hline $88 \mathrm{R}$ & 88.1 & Boat Beach & $\mathrm{R}$ & 3,070 & 1.2 & 1.3 & 3.4 \\
\hline $91 R^{*}$ & 91.8 & 91 Mile & $\mathrm{S}$ & 4,490 & 1.3 & 1.2 & 4.2 \\
\hline $93 \mathrm{~L} *$ & 93.8 & Granite & $\mathrm{U}$ & 3,590 & 1.7 & 1.8 & 2.9 \\
\hline $104 R^{*}$ & 104.4 & Upper 104 Mile & $\mathrm{R}$ & 1,020 & 1.3 & 1.0 & 3.9 \\
\hline $119 R^{*}$ & 119.4 & Big Dune & $\mathrm{R}$ & 8,930 & 1.6 & 1.3 & 4.6 \\
\hline $120 \mathrm{R}$ & 119.8 & 119 Mile Camp & $\mathrm{R}$ & 10,080 & 1.9 & 1.3 & 4.5 \\
\hline $122 \mathrm{R} *$ & 122.7 & 122 Mile Camp & $\mathrm{R}$ & 8,240 & 2.2 & 2.1 & 4.2 \\
\hline $123 \mathrm{~L}^{*}$ & 123.3 & Upper Forster & $\mathrm{R}$ & 8,050 & 1.4 & 1.3 & 4.0 \\
\hline $137 \mathrm{~L}^{*}$ & 137.7 & Football Field & $\mathrm{R}$ & 5,140 & 1.2 & 1.2 & 4.3 \\
\hline $139 R^{*}$ & 139.6 & Fishtail & $\mathrm{U}$ & 7,190 & 1.3 & 1.2 & 4.5 \\
\hline $145 \mathrm{~L}^{*}$ & 145.8 & Above Olo & $\mathrm{R}$ & 1,320 & 1.4 & 1.5 & 5.0 \\
\hline $165 \mathrm{R}$ & 165.7 & 165 Mile & $\mathrm{S}, \mathrm{R}$ & 5,150 & 1.1 & 0.9 & 4.6 \\
\hline $166 \mathrm{~L}$ & 167.2 & Lower National & $\mathrm{S}$ & - & 2.4 & 1.1 & 3.6 \\
\hline
\end{tabular}


Table 1. Channel geometry and geomorphic characteristics for selected study sites, Colorado River in Marble and Grand Canyons.-Continued

[Site names are from Belknap (2001) and Stevens (1990) or are informally used. **, sites surveyed before and after the 1996 and 2004 HFEs. *, sites surveyed before and after the 1996 HFE. -, not determined because bathymetry data were not collected at the site.]

\begin{tabular}{|c|c|c|c|c|c|c|c|}
\hline \multirow{2}{*}{$\begin{array}{l}\text { Site } \\
\text { ID }^{1}\end{array}$} & \multirow{2}{*}{$\begin{array}{l}\text { River } \\
\text { Mile } \\
(\mathbf{R M})^{2}\end{array}$} & \multirow[b]{2}{*}{ Site Name } & \multirow{2}{*}{$\begin{array}{c}\text { Deposit } \\
\text { Type }^{3}\end{array}$} & \multirow{2}{*}{$\begin{array}{l}\text { Eddy } \\
\text { Size } \\
\left(\mathrm{m}^{2}\right)^{4}\end{array}$} & \multicolumn{2}{|c|}{ Expansion Ratio ${ }^{5}$} & \multirow{2}{*}{$\begin{array}{c}\text { Stage } \\
\text { Change }^{6} \\
\text { (m) }\end{array}$} \\
\hline & & & & & $\begin{array}{c}242 \\
\left(\mathrm{~m}^{3} / \mathrm{s}\right)\end{array}$ & $\begin{array}{l}1,203 \\
\left(\mathrm{~m}^{3} / \mathrm{s}\right)\end{array}$ & \\
\hline $172 \mathrm{~L}^{*}$ & 172.6 & Below Mohawk & $\mathrm{R}$ & 9,400 & 1.3 & 1.3 & 3.9 \\
\hline $183 \mathrm{~L}^{*}$ & 183.3 & Below Chevron & $\mathrm{R}$ & 5,150 & 1.7 & 1.6 & 4.1 \\
\hline $194 R^{*}$ & 194.6 & Hualapai Acres & $\mathrm{R}$ & 14,140 & 2.2 & 2.1 & 3.8 \\
\hline $201 R$ & 201.6 & & $\mathrm{R}$ & 12,060 & 2.5 & 1.4 & 3.4 \\
\hline $202 R^{*}$ & 202.3 & 202 Mile & $\mathrm{S}, \mathrm{R}$ & 15,620 & 2.7 & 1.7 & 3.8 \\
\hline $213 L^{*}$ & 213.3 & $\begin{array}{l}\text { Pumpkin } \\
\text { Springs }\end{array}$ & $\mathrm{U}$ & 3,990 & 3.1 & 2.4 & 5.8 \\
\hline $214 \mathrm{R}$ & 214.5 & 214 Mile & $\mathrm{R}$ & 5,250 & 1.4 & 1.1 & 3.8 \\
\hline $220 \mathrm{R}^{*}$ & 220.1 & Middle 220 & $\mathrm{U}$ & 2,450 & 1.4 & 1.1 & 3.0 \\
\hline $225 \mathrm{R}^{*}$ & 225.5 & & $\mathrm{R}$ & 5,635 & 2.3 & 1.8 & 2.9 \\
\hline
\end{tabular}

${ }^{1}$ The descriptors "L" and "R" denote the location of the emergent sandbar on left and right sides of the river, respectively, facing downstream.

${ }^{2}$ Approximate location based on the river mile centerline (U.S. Geological Survey, 2006) downstream from Lees Ferry (river mile 0), in Grand Canyon National Park.

${ }^{3}$ Deposit type: $\mathrm{R}$, reattachment bar, $\mathrm{S}$, separation bar, $\mathrm{U}$, undifferentiated eddy bar.

${ }^{4}$ Eddy size determined by a fixed boundary between the main channel and eddy located at the base of the eddy sandbar.

${ }^{5}$ Average channel width in expansion with associated eddy divided by average channel width in nearest upstream or downstream constriction. Channel width determined using the method for generating cross-sections by Magirl and others (2008).

${ }^{6}$ Difference in water-surface elevation between the $227-\mathrm{m}^{3} / \mathrm{s}$ and $1,203-\mathrm{m}^{3} / \mathrm{s}$ stage (Hazel and others, 2006b).

exceeded $1,175 \mathrm{~m}^{3} / \mathrm{s}$ at the USGS streamflow-gaging station at Lees Ferry (09380000; fig. 1), beginning at 0600 hours (Pacific Standard Time) on March 6 and ending at 1830 hours on March 8, the mean discharge was $1,203 \mathrm{~m}^{3} / \mathrm{s}$. The downramp rate was $43 \mathrm{~m}^{3} / \mathrm{s}$ per hour until the normal hydropower plant releases scheduled for March were reached. In the first month following the 2008 HFE, diurnal peak flows were between 325 and $390 \mathrm{~m}^{3} / \mathrm{s}$, with daily fluctuations of 142-227 $\mathrm{m}^{3} / \mathrm{s}$. On April 15, 2008, releases were increased to diurnal peak flows of $425-462 \mathrm{~m}^{3} / \mathrm{s}$. In summer, monthly discharges were higher, with diurnal peaks flows of $500-530 \mathrm{~m}^{3} / \mathrm{s}$ and daily fluctuations of $200-227 \mathrm{~m}^{3} / \mathrm{s}$. In September and October 2008 , there was a steady release regime of $354 \mathrm{~m}^{3} / \mathrm{s}$. These major changes in flow regime allow comparison of sandbar stability under relatively lower fluctuating flows associated with normal spring operations (typically referred to as the modified low fluctuating flow dam operation) followed by the response after higher summer operations.

\section{Methods}

Repeated high-resolution topographic surveys were made on five river trips in 2008 (fig. 3). Each measurement site is located in the downstream part of a fan-eddy complex (fig. 2A). Sixty-two emergent sandbars, consisting of reattachment and/or separation bars, were surveyed down to the $227-\mathrm{m}^{3} / \mathrm{s}$ stage at 57 sites (appendix A). Three study sites were not surveyed on the February 2008 river trip (50R, 56R, and 62R), and we utilized data collected in October 2007 as the pre2008 HFE site condition at these sites. Subaerial topography 
and campsite areas were surveyed with Topcon GTS-313 and Topcon GPT-2003 electronic total stations.

Bathymetry was measured and analyzed at 40 sites on the February and April trips with a multibeam sonar system installed on a 7-m motorized raft (appendix A). These measurements expanded the survey area to include the bed of the eddy and adjacent main channel, such that the entire area of sand and water ever inundated since 1990 was included in the survey. Typically, the longitudinal extent of each bathymetric survey was from the downstream end of the rapid or riffle to approximately one to two channel widths downstream of the eddy that existed at the time of the survey.

The combined topographic and bathymetric data have a positional accuracy better than $0.10 \mathrm{~m}$ and elevation accuracy that varies from $0.05 \mathrm{~m}$ or less for points acquired by total station to $0.10 \mathrm{~m}$ or less for bathymetric points. Point data were referenced to the Arizona State Plane NAD83, Arizona Central (FIPS 202) coordinate system, in meters, using established benchmarks. Specific details and error analysis of the topographic surveying techniques and the multibeam system are described by Hazel and others (2008) and Kaplinski and others (2009), respectively.

The topographic and bathymetric point data for each study site were combined, and digital elevation models (DEMs) at 1-m resolution were constructed by building triangulated irregular networks (TINs) using Delaunay triangulation (McCullagh, 1988). Changes in topography were determined by subtracting the pre-2008 HFE DEM from the post-2008 HFE DEM to generate erosion-deposition maps. Kaplinski and others (2009) reported an average uncertainty of 5 percent in topographic surfaces generated using the same methods used in this study.

The topographic surfaces were used to compute sand deposit volume within the two geomorphic settings that occur in the channel expansion: the eddy and the bed of the adjacent channel (fig. 2B). Because the size and exact position of the eddy change as a function of discharge, a fixed eddy boundary was delineated. This boundary divides the eddy from the main channel at the base of the eddy sand deposit (fig. 2B). Thus, the eddy for computational purposes includes all deposits separated from the main channel within the region between the separation and reattachment points of the eddy. Hereafter, we use "total eddy" to refer to this computational area. Sandbar deposits above the reference stage outside the eddy were not surveyed; thus the main-channel environment consists entirely of sand deposits below the $227-\mathrm{m}^{3} / \mathrm{s}$ water-surface elevation. To examine the entire site or channel-expansion response, we refer to the combined total eddy and main channel volumes as "total site sand volume." However, it is not possible to report absolute sand volumes, because depths to the gravel, boulder, or bedrock substrate are known only for a very few locations (Rubin and others, 1994). Thus, the sand volumes reported in this study are computed by determining the volume of sand above a synthetically constructed minimum surface

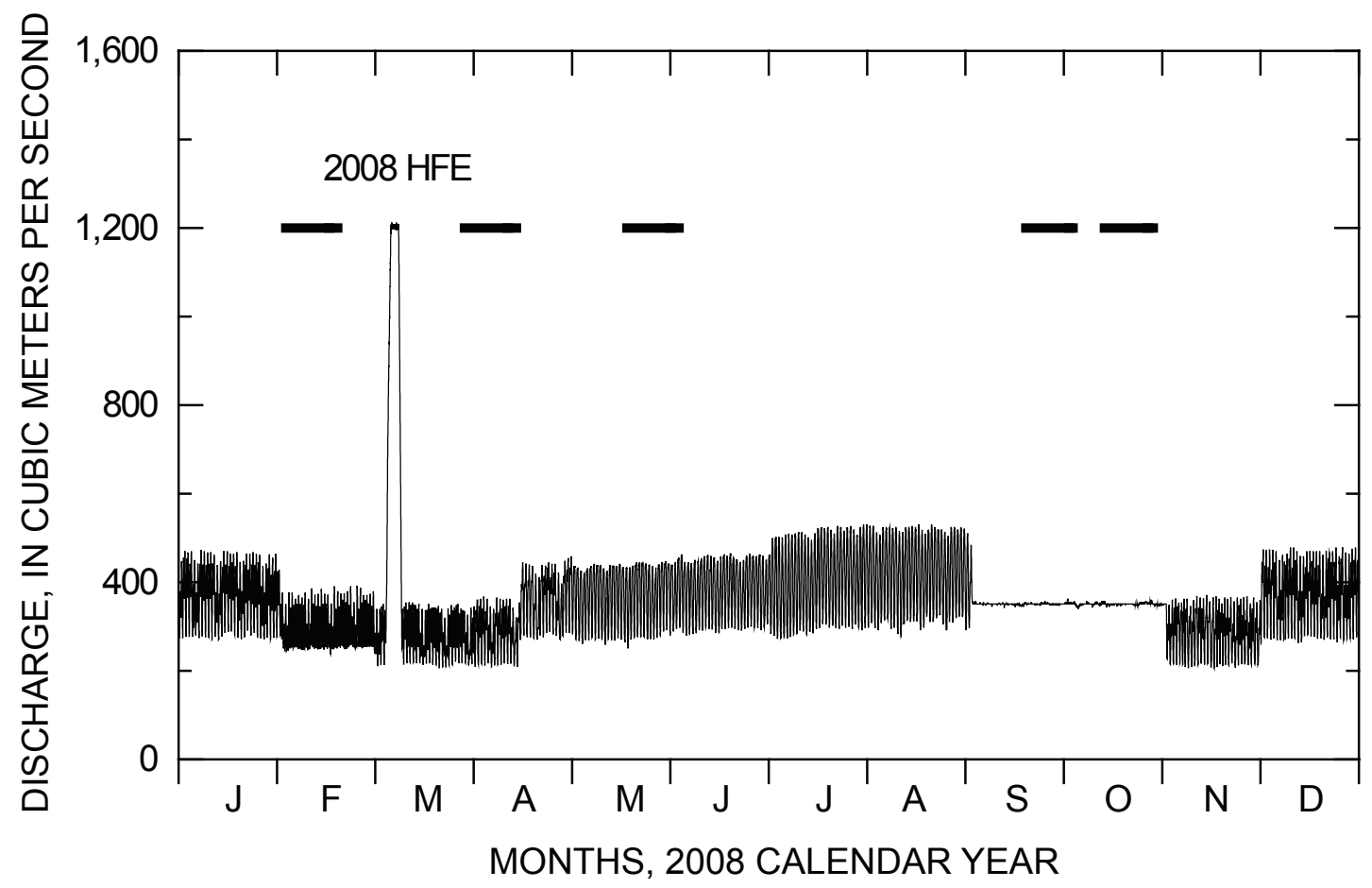

Figure 3. Instantaneous discharge of the Colorado River at USGS streamflow-gaging station (09380000), Lees Ferry, Arizona, for the 2008 calendar year. The solid, horizontal lines indicate the times of survey river trips. 
(fig 2C). The minimum surface was computed by determining the lowest sandbar elevation ever measured for each 1-m grid cell using all surveys for each study site, including all measurements made from 1990 to 2008. The minimum sandbar surface thus separates sediment that has never changed for the period of monitoring (below the minimum surface) from sediment that has been active during the period of monitoring. The minimum surfaces used in this report are an update of the minimum surfaces computed and described by Hazel and others (2006a). We also computed maximum sandbar surfaces with the same method in order to determine the percentage of the total eddy area filled at any given time by an eddy sandbar. Thus, we defined a reference eddy sand-storage volume for each site as the maximum volume of sand that can possibly be stored within the eddy below the maximum surface.

To examine sandbar response within the total eddy computational area, we differentiate between three elevation zones (figs. $2 B$ and $C$ ). The low-elevation zone is defined as the volume of sand between the calculated minimum surface and the elevation of the reference stage of $227 \mathrm{~m}^{3} / \mathrm{s}$. The midelevation zone is the region between the reference stage and the water surface elevation at a higher topographic level defined as the elevation reached by a discharge of $708 \mathrm{~m}^{3} / \mathrm{s}$. The high-elevation zone includes the region above the $708-\mathrm{m}^{3} / \mathrm{s}$ water-surface elevation. We refer to the combined mid- and high-elevation zones as sand storage above the reference stage. These elevation zones were selected because $227 \mathrm{~m}^{3} / \mathrm{s}$ represents the lowest discharge typical of normal hydropower plant operations and $708 \mathrm{~m}^{3} / \mathrm{s}$ represents the highest discharge of normal daily hydropower plant operations. The stage elevations for flows of 227 and $708 \mathrm{~m}^{3} / \mathrm{s}$ were derived from the stage-discharge relations of Hazel and others (2006b). At some sites that had not been surveyed previously, new relations were computed using similar methods.

The thickness of sandbars resulting from the $2008 \mathrm{HFE}$ was determined from the change in sand volume over a defined area for each site within four bins that increase in spatial scale: high-elevation sand (within the eddy), sand above reference stage (within the eddy), total sand within the eddy, and total sand within the study site. To determine total sand thickness in eddies and total sand thickness within entire study sites, the total volume change at all zonal elevations within an eddy and the combined eddy and channel were divided by the measured area of the respective zones. Because the portion of the sandbar exposed above the reference stage occupies a small percentage of the overall eddy area, high-elevation sand thickness and the thickness of the sand above the reference stage were determined by dividing the volumetric change by the area of the maximum sandbar surface (that is, an estimate for the maximum potential sandbar area was computed with the same method as the minimum surface).

Post-2008 HFE bar stability was evaluated by comparing sandbar thickness above the reference stage at a 36-site subset of the study sites collected in May 2008 to surveys at the same sites collected in September and October 2008 (appendix A). In order to calculate erosion rates, we divided volume change above the reference stage by the number of days between successive surveys at each site. To observe short-term changes at the sites and also to help interpret longer term changes, a combination of remote analog and digital cameras were utilized to collect repeated daily oblique images at 32 of the sites (appendix A).

To evaluate sandbar response in comparison with suspended-sand concentration, the study sites were grouped into reaches of similar sand concentration during the 2008 HFE (table 2), based on proximity to the fixed sedimentmonitoring stations and also to measurements of suspendedsand concentration collected longitudinally during the 2008 HFE (D. Topping, U.S. Geological Survey, written commun., 2009). A subset of the study sites were analyzed for comparison of the 2008 HFE results with results from the two previous HFEs in 1996 and 2004. For comparing total sand volume, there were 29 sites where sufficient data were collected in 1996 and 2008 to make comparisons (table 1). Of these sites, 10 sites in UMC, LMC, and EGC were also surveyed in 2004 (table 1). For comparisons of sand volume above reference stage, there were 38 sites that could be compared between 1996 and 2008 and 22 sites in UMC, LMC, and EGC that could be compared between 2004 and 2008. To compare sand volumes following the 2008 HFE, the measured values were normalized as the ratio of sand volume measured following each of the HFEs to the sand volume measured immediately before the 1996 HFE. This method of normalizing the data is consistent with the method used when analyzing such data for the 1996 HFE (Hazel and others, 1999) and the 2004 HFE (Topping and others, 2006a). These normalized data were used to compute cumulative probability distributions and median response for each of the reaches of similar suspended-sediment concentration corresponding to the sediment-flux monitoring reaches (fig. 1).

Campsite area as measured in this study is the area of the sandbar that can be used as a kitchen or a place to sleep. We adopted the criteria of Kearsley and Warren (1993) in defining campsite area as that part of the sandbar with no more than an 8 degree slope and little or no vegetation. Slope angle was estimated by observation in the field. Points were surveyed that outline the perimeter of each camping area, as well as points surrounding features to exclude from the camping area, such as trees, bushes, and rocks (Kaplinski and others, 2005). The perimeter points were then used to define polygons of campsite area. Plan areas of the campsite area TIN models were summarized for high-elevation and midelevation zones.

The campsite measurements were analyzed by their occurrence in "critical" and "noncritical" camping reaches. A critical reach was defined by Kearsley and Warrren (1993) as any contiguous stretch of the river in which the number of available campsites is limited because of geologic characteristics, high demand, or other logistical factors. Noncritical reaches were defined as any stretch of the river in which campsites are plentiful and little competition occurs for the majority of sites. There are presently more than 220 actively used river campsites in the Grand Canyon National Park 
Table 2. Sediment-transport flux-monitoring stations and reaches of the Colorado River used to compare the 1996, 2004, and 2008 HFEs.

[RM, approximate location based on the river mile centerline (U.S. Geological Survey, 2006) downstream from Lees Ferry (river mile 0) in Grand Canyon National Park. The descriptors "L" and "R" denote the location of the emergent sandbar on left and right sides of the river, respectively, facing downstream.]

\begin{tabular}{|c|c|c|c|c|}
\hline \multirow{2}{*}{ Reach } & \multirow{2}{*}{$\begin{array}{c}\text { Sedinent- } \\
\text { transport flux } \\
\text { monitoring } \\
\text { reach (RM) }\end{array}$} & \multirow{2}{*}{$\begin{array}{l}\text { Corresponding } \\
\text { reach of similar } \\
\text { suspended- sedi- } \\
\text { ment concentration } \\
\text { (RM) }\end{array}$} & \multicolumn{2}{|c|}{$\begin{array}{l}\text { Upstream and downstream study site } \\
\text { used for comparison among high flows }\end{array}$} \\
\hline & & & $\begin{array}{l}\text { Total site sand } \\
\text { volume }\end{array}$ & $\begin{array}{l}\text { Sand volume above } \\
\text { reference stage }\end{array}$ \\
\hline $\begin{array}{l}\text { Upper } \\
\text { Marble } \\
\text { Canyon }\end{array}$ & $0-30$ & $15-40$ & $22 \mathrm{R}-32 \mathrm{R}$ & $16 \mathrm{~L}-32 \mathrm{R}$ \\
\hline $\begin{array}{l}\text { Lower } \\
\text { Marble } \\
\text { Canyon }\end{array}$ & $30-61$ & $40-65$ & $43 \mathrm{~L}-65 \mathrm{R}$ & $43 \mathrm{~L}-65 \mathrm{R}$ \\
\hline $\begin{array}{l}\text { Eastern } \\
\text { Grand } \\
\text { Canyon }\end{array}$ & $61-87$ & $65-130$ & $68 \mathrm{R}-123 \mathrm{~L}$ & $68 \mathrm{R}-123 \mathrm{~L}$ \\
\hline $\begin{array}{l}\text { Central } \\
\text { Grand } \\
\text { Canyon }\end{array}$ & $87-166$ & $130-180$ & $137 \mathrm{~L}-172 \mathrm{~L}$ & $137 \mathrm{~L}-172 \mathrm{~L}$ \\
\hline $\begin{array}{l}\text { Western } \\
\text { Grand } \\
\text { Canyon }\end{array}$ & $166-225$ & $180-225$ & 194L-225R & $183 \mathrm{~L}-225 \mathrm{R}$ \\
\hline
\end{tabular}

inventory of camps between Lees Ferry and Diamond Creek (http://www.nps.gov/grca/parkmgmt/riv_camp-atlas.htm). The number of campsites per river mile in noncritical reaches is about twice that in critical reaches (table 3). Sixteen of the sandbar monitoring sites chosen for campsite monitoring in this study are located within critical reaches, and 21 occur in noncritical reaches.

\section{Results}

\section{Overview of Topographic Response}

Deposition in the high-elevation zone occurred at nearly every study site. The volume of sand in this zone increased by more than 5 percent at 48 of the 57 sites surveyed (appendix B, table B1). The median change in high-elevation deposit thickness was $0.21 \mathrm{~m}$, and virtually all sites aggraded to some extent (fig. 4A). Nearly every measured eddy bar aggraded above the reference stage; however, the changes were more variable in the midelevation zone than observed in the high-elevation zone (appendix B, table B2). As a result, the median change in sand thickness above the reference stage was $0.26 \mathrm{~m}$, but the changes from site to site were more variable (fig. $4 B$ ).

Because of substantial variability in the low-elevation eddy zone and on the bed of the main channel (appendix B, table
B3), the total eddy sand thickness change ranged from -1.88 to $1.13 \mathrm{~m}$ (fig. 4C). Fifty percent of the sites had a total eddy sand thickness change of $0.10 \mathrm{~m}$ or greater. In many cases, net deposition above the reference stage in eddies was approximately balanced by net erosion below the reference stage. Sandbar thickness change was also computed for each site, including above and below reference stage for all parts of the channel and eddies. Total site changes were highly variable, ranging from -2.27 to $0.80 \mathrm{~m}$, with a median of $0.06 \mathrm{~m}$ (fig. $4 D$ ).

\section{Styles of Topographic Response}

The widespread deposition at all high-elevation sites and at most sites in the midelevation zone, and the variability in the low-elevation eddy zone and on the bed of the main channel, resulted in increases or decreases in total-site sand volume. Therefore, we examined the exchange between highand low-elevation areas of each study site by comparing the transfer of sand above and below the reference-stage elevation. These responses were categorized into four styles of topographic change depending on the combination of $(\mathrm{A})$ net change in sandbar volume within the eddy boundary above reference stage and (B) net change in volume for the entire site, including the channel and eddy below reference stage (fig. 5). The Style 1 response consisted of net increase in 
volume (deposition) at all elevations above and below reference stage, and this style characterized 45 percent of the study sites. The Style 2 response consisted of net decrease in volume (erosion) in the eddy and channel below reference stage and net deposition in the eddy above base flow stage. This was the second most common response and occurred at 37 percent of the sites. The Style 3 response occurred where there was net erosion at all elevations above and below reference stage; this style characterized 16 percent of the measurement sites. The Style 4 response consisted of net erosion above reference stage and net deposition below reference stage. In the following section, we present examples of these response styles to illustrate some of their characteristics and show how erosion and deposition were distributed across individual sites. Because response Style 2 included some sites where there was net erosion across the channel and eddy and some sites where there was net deposition, an example of each case is included. Style 4 response was weak (nearly, a Style 1 response) and occurred at only 1 site; therefore, that response style is not discussed in detail.

\section{Style 1}

The most common 2008 HFE response (Style 1) was one in which sand deposition increased the sand volume both above and below reference stage. In all of these sites there was net deposition in the eddy and in the entire study site. An example is $172 \mathrm{~L}$, where the post-2008 HFE volume at low elevation exceeded the pre-2008 HFE volume by 11 percent and the post-2008 HFE volume above reference stage exceeded the pre-2008 HFE volume by 29 percent (based on values reported in appendix B). The changes at this site are broadly representative of this style of response, although the magnitudes of proportional changes were greater at some sites (fig. 5). In February 2008, a reattachment bar was present and the bar surface was covered by tamarisk (Tamarix ramosissima) near the talus slope and by arroweed (Pluchea sericea) along the shoreline (fig. 7A). In the high-elevation zone, the bar was eroding along a steep cutbank at the downstream end. The return-current channel was well defined at high elevation but nonexistent at flows in the low range of typical diurnal dam operating releases. Dunes present on the bed in the channel indicate that the bed was either sand or fine gravel. At the time of the February 2008 survey, the bar volume was 66 percent of the reference eddy-storage volume at the site.

Deposition by the flood was greatest on the sandbar platform (fig. $6 B$ ). Much of the vegetation that had colonized the bar surface was buried beneath 1 to $2 \mathrm{~m}$ of sand (fig. $7 C$ ). Further upstream, there was deposition at low elevation, increasing the elevation of the bar platform. A distinct returncurrent channel separated the new deposit from the bank, as shown by the location of the $227-\mathrm{m}^{3} / \mathrm{s}$ stage elevation in figure $6 B$. The post-2008 HFE sandbar increased to 85 percent of the total eddy-storage volume above reference stage.

The areal and volumetric change distributions calculated from the erosion-deposition map at 172L are shown in figure
Table 3. Critical and noncritical recreational campsite reaches of the Colorado River (modified from Kearsley and Warren, 1993.

\begin{tabular}{|c|c|c|c|c|}
\hline \multirow{2}{*}{$\begin{array}{l}\text { Reach } \\
\text { number }\end{array}$} & \multirow{2}{*}{ Reach name } & \multirow{2}{*}{$\begin{array}{c}\text { Number of } \\
\text { campsites } \\
\text { per mile }^{1}\end{array}$} & \multicolumn{2}{|c|}{ River mile } \\
\hline & & & Starting & Ending \\
\hline 1 & Noncritical & 0.5 & 0 & 11 \\
\hline 2 & Critical & 1.1 & 11 & 41 \\
\hline 3 & Noncritical & 1.5 & 41 & 77 \\
\hline 4 & Critical & 0.9 & 77 & 116 \\
\hline 5 & Noncritical & 1.7 & 116 & 139 \\
\hline 6 & Critical & 0.7 & 139 & 164 \\
\hline 7 & Noncritical & 1.1 & 164 & 226 \\
\hline
\end{tabular}

'Primary campsites originally inventoried by Kearsley and Warren (1993) and still considered active by Grand Canyon National Park (http://www.nps.gov/grca/parkmgmt/riv_camp-atlas.htm).

8 . These changes are represented as histograms that show the area of the bed and volume of sand associated with each increment of bed elevation change. A unimodal distribution of change, in which $5,800 \mathrm{~m}^{2}$ of the total eddy was increased 0.25 to $1.0 \mathrm{~m}$ in elevation (62 percent of the eddy computational area), was also observed, as shown in figure $8 \mathrm{~A}$. A large part of the channel, about $5,600 \mathrm{~m}^{2}$, increased by 0.25 to 0.5 $\mathrm{m}$ in elevation (64 percent of the channel computational area). Because the change in sand volume is the product of elevation change and the area over which that change occurred, the greatest volume of deposition occurred where the elevation increased between 0.75 and $1.0 \mathrm{~m}$, and the greatest deposition in the channel occurred where the elevation increased 0.25 to $0.5 \mathrm{~m}$. There was a total of $3,657 \mathrm{~m}^{3}$ of net deposition in the eddy and $1,595 \mathrm{~m}^{3}$ of net deposition in the channel. The site as a whole gained $5,252 \mathrm{~m}^{3}$ of sand (all reported values are listed in the tables contained in appendix B).

\section{Style 2 With Net Eddy Erosion}

There were many sites where sand deposited above the reference stage but erosion occurred below that elevation. At some of these sites, both the eddy and channel environments were dominated by erosion, while at others there was net deposition in the eddy with a larger magnitude of net erosion in the adjacent channel. The changes at Eminence Break (44L) illustrate the Style 2 response for sites where there was net 
erosion within the eddy even though deposition occurred in mid- and high-elevation zones (fig. 9).

A large separation bar mantled the Eminence Break debris fan. In February 2008, the separation bar had two distinct topographic levels: the sand below the stage of 708 $\mathrm{m}^{3} / \mathrm{s}$ gradually sloped toward the river; higher parts of the separation bar were partially vegetated, with scattered dunes (fig. 10A). The reattachment bar at the midelevation zone had a large platform, and there was a well-defined return channel shoreward from the sandbar (fig. 9A). The high-elevation zone of the reattachment bar was thickly vegetated and sloped steeply down to the midelevation surface. In the main channel, there was a scour hole adjacent to the eddy. At the time of the February 2008 survey, the volume of the eddy bars increased by 62 percent of the reference eddy-storage volume.

Flood deposition was greatest on the downstream part of the reattachment bar, and erosion occurred in the upstream part of the eddy (fig. 9B). Deposition occurred on both bars at mid and high elevations. The return-current channel was widened and deepened through scour (note the new location of the $227-\mathrm{m}^{3} / \mathrm{s}$ stage elevation in figure $9 B$ ). Deposition on the eddy bar above reference stage increased sand volume to 80 percent of the reference eddy-storage volume. However, the 2008 HFE eroded more sand than was deposited at the site, because as much as $6 \mathrm{~m}$ of sand eroded from the lowelevation eddy zone by scour of the upstream reattachment bar (fig. 9C). In the main channel, there was erosion of sand adjacent to the scoured area of the eddy and sand deposition on the pool exit slope associated with growth of a dune field (fig 10B)

The distribution of elevation change in figure $11 \mathrm{~A}$ shows a bimodal distribution, with widespread, relatively lowmagnitude deposition (0.25-1.0 m) over an area of $\sim 11,000$ $\mathrm{m}^{2}$ (42 percent of the total eddy area). The erosion of the upstream reattachment bar resulted in a smaller area $(\sim 7,500$ $\mathrm{m}^{2}$ ) with a depth of scour ranging from 1 to $5 \mathrm{~m}$. In contrast, growth of the dune field on a large region of the channel bed $\left(\sim 11,500 \mathrm{~m}^{2}\right)$ increased the sand elevation by 0.25 to $1.5 \mathrm{~m}$

\section{A High-elevation zone}

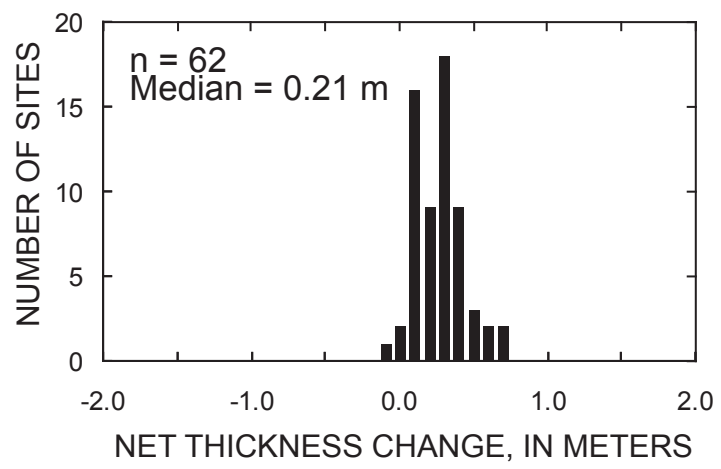

C Total eddy

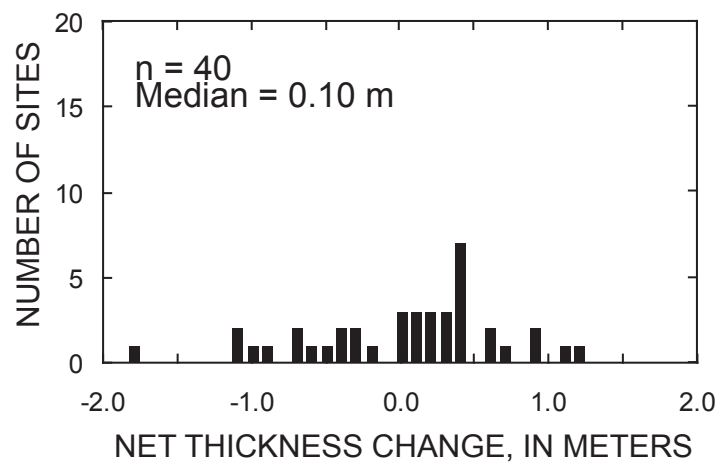

\section{$B$ Above reference stage}

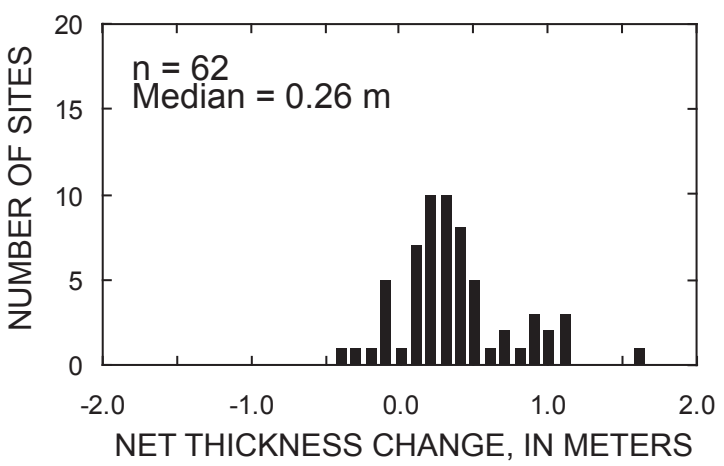

$D$ Total site (eddy and channel)

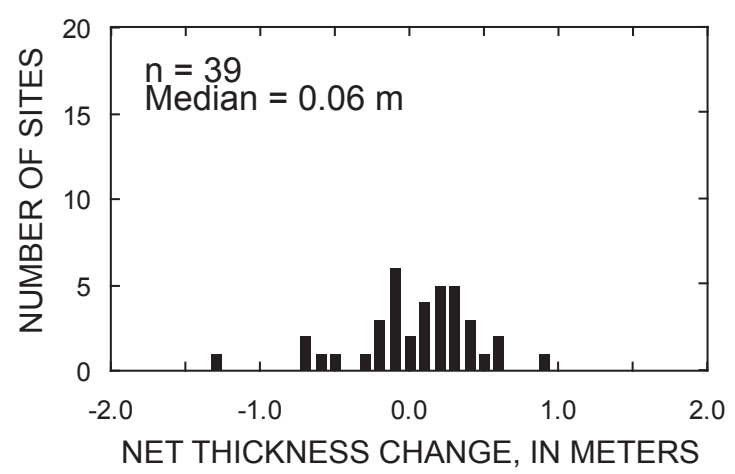

Figure 4. Histograms of net sandbar thickness change between February and April 2008. $A$, High-elevation zone. $B$, Above reference stage. $C$, Total eddy. $D$, Total site (combined eddy and channel). 
(66 percent of the channel area; fig. 11B). Because erosion of more than $6 \mathrm{~m}$ from the eddy was greater than the volume of sand deposited in the channel, the balance was toward net erosion at the site. There was a total of $13,132 \mathrm{~m}^{3}$ of net sand erosion in the eddy and $4,115 \mathrm{~m}^{3}$ of net deposition in the channel, resulting in total site erosion of $9,017 \mathrm{~m}^{3}$.

\section{Style 2 With Net Eddy Deposition}

A different variant of Style 2 is one in which there was net deposition in eddies (fig. 5). The changes at site 65R are typical of this style, where high-elevation eddy deposition exceeded low-elevation erosion (fig. 12). At 65R, lowelevation erosion reduced the volume of sand by 24 percent (based on values reported in appendix B) and deposition above the reference stage increased the volume of sand by about 300 percent. In February 2008, the separation bar was characterized by a zone of interspersed sand and boulders on the downstream end of the debris fan. A popular camp was located on a flat and level area on the downstream end of the separation bar. Only the highest part of the reattachment bar at the downstream end of the eddy was exposed at typical dam operating releases. A cutbank 2 to $3 \mathrm{~m}$ high separated the high-elevation sand deposit from the midelevation bar. A large reattachment bar occupied most of the low-elevation zone in the eddy (fig. 12A).

Deposition was greatest in the downstream part of the eddy, where as much as $3 \mathrm{~m}$ of elevation increase occurred on the bar crest and platform, along and in front of the steep cutbank (fig. 12C). At this formerly low-elevation part of the eddy, the return-current channel was partially filled with sand as the reattachment bar aggraded toward the bank. Further upstream, a deeper return channel was excavated where more than $2 \mathrm{~m}$ of sand eroded from the upstream part of the reattachment bar. The deposition increased the eddy reference storage volume to 68 percent of maximum, and an extensive, uniform reattachment bar platform occupied a large region of the eddy above reference stage (fig. 13A).

Widespread, relatively high-magnitude deposition (1.0$3.25 \mathrm{~m}$ ) occurred over approximately $6,000 \mathrm{~m}^{2}$ of the total eddy area (fig. 14A). Erosion also occurred over a similar-sized area of the eddy, but the erosion was to a depth of 0.25-2.0 m (on average, less than the deposition), resulting in net eddy deposition. In the channel, moderate erosion $(0.75-1.25 \mathrm{~m})$ occurred over 7,500 $\mathrm{m}^{2}$ (83 percent of the channel area) of the bed (fig. $14 B$ ). As at most other sites, erosion in the low-elevation zone of the eddy was accompanied by net erosion in the channel. There was a total of $5,294 \mathrm{~m}^{3}$ of net deposition in the eddy and $5,975 \mathrm{~m}^{3}$ of net erosion in the channel, so the total site response was a net loss in sand volume of $681 \mathrm{~m}^{3}$. Nonetheless, both separation and reattachment bars substantially aggraded.

\section{Style 3}

Changes at site $3 \mathrm{~L}$ illustrate the Style 3 response (fig. 15), wherein there was net erosion of both the eddy and main channel. At the time of the first survey in February 2008, the bar occupied 47 percent of the eddy. The highest part of the bar was at the downstream end of the eddy, and a well-defined return-current channel existed between a large reattachment-bar platform and the channel bank (figs. 15A, 16A). The channel bed shallowed downstream from the scour hole, and dunes covered much of the channel bed downstream from the eddy.

Nearly the entire reattachment bar was inundated by the 2008 HFE (fig. 16B), and the topography of the bar and channel was significantly modified (fig. 15B). The only area of deposition was at the downstream

Figure 5. Relation of proportional sand-volume change above reference stage (combined high-elevation and midelevation eddy zones) to below reference stage (combined low-elevation eddy and channel zones) for each site between February and April 2008. The four response styles (Styles 1, 2, 3, and 4) and specific example sites described in the text are shown. Also indicated is net total-eddy deposition or fill as indicated by the net thickness changes shown in figure $4 C$. 


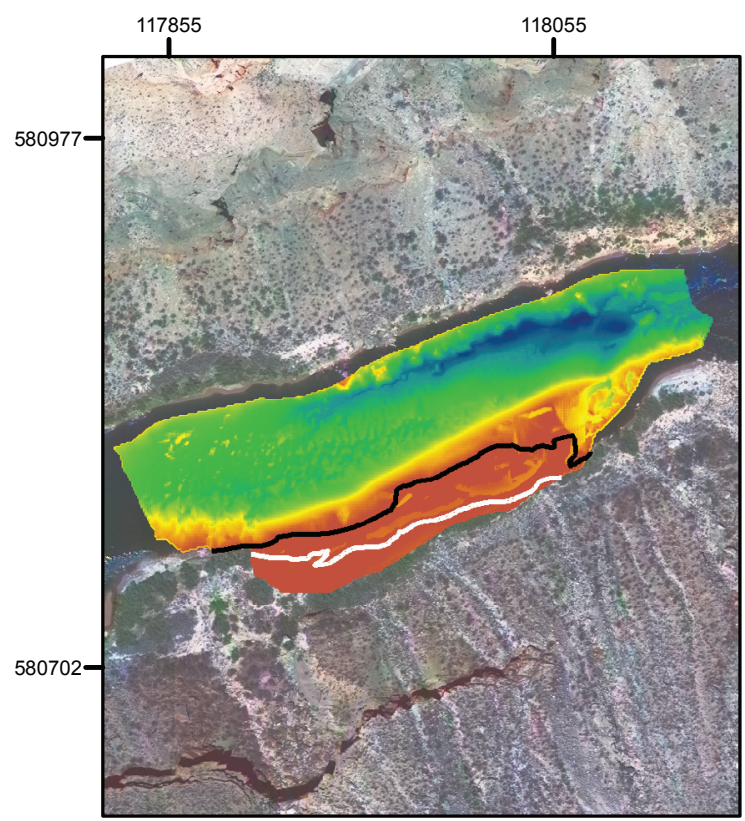

A Pre-2008 HFE DEM

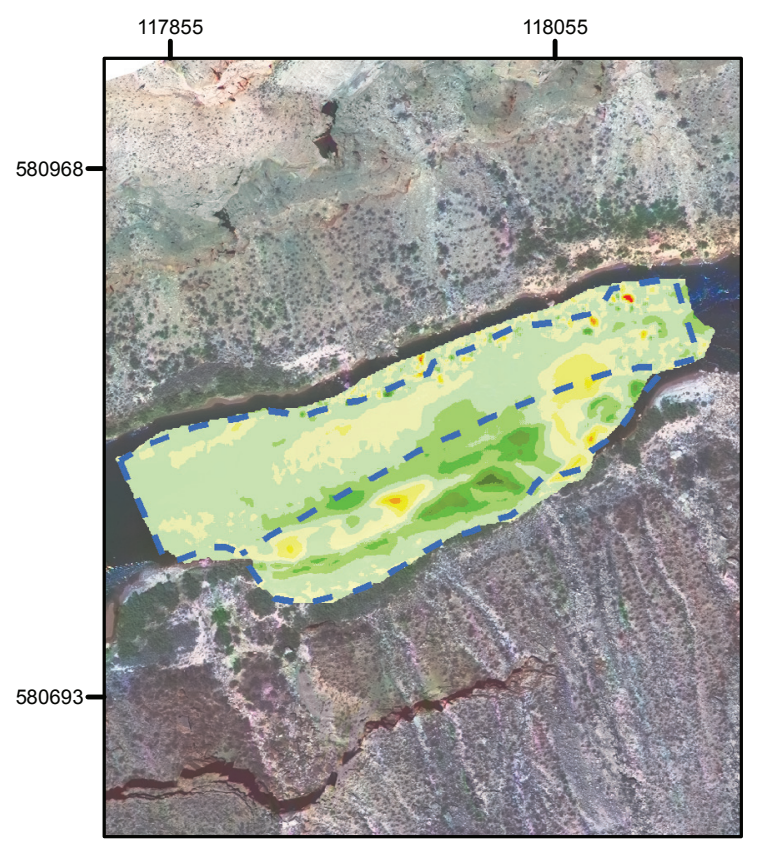

C Erosion-deposition map

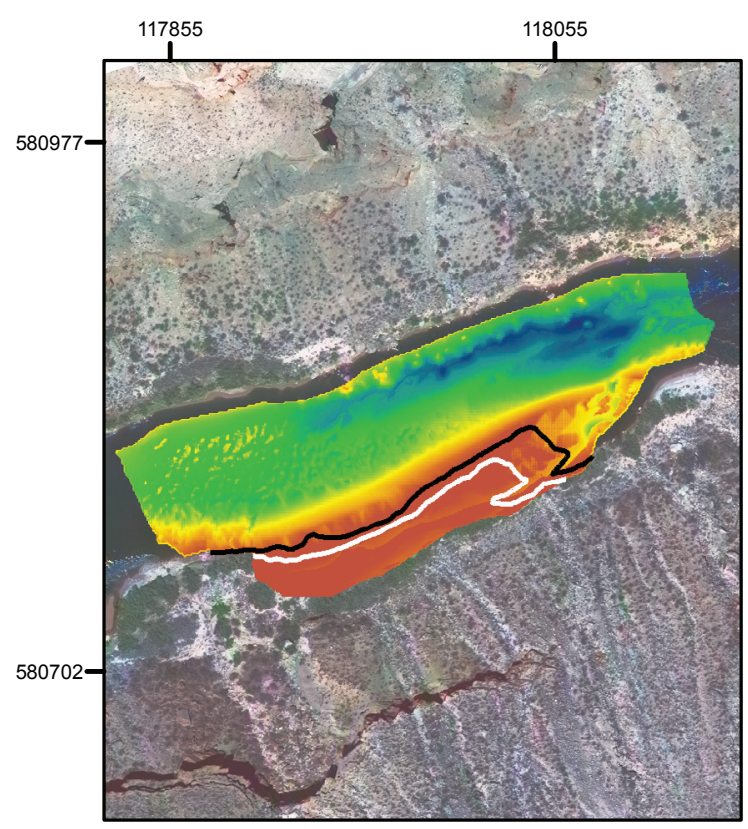

B Post-2008 HFE DEM

\section{Explanation}

DEM - Elevation in $A$ and $B$

(m)
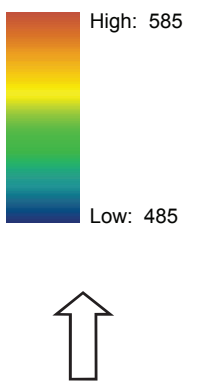

Elevation Change in $C$

(m)

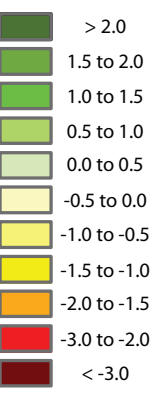

$\mathbf{N}$

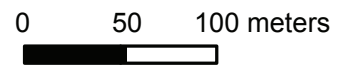

Figure 6. Comparison of repeat topographic and bathymetric surveys collected at site 172L illustrating Style 1 site response. $A$, Pre-2008 HFE digital elevation model (DEM). $B$, Post-2008 HFE DEM. C, The DEMs were differenced against each other to produce a map of spatially distributed elevation change. The solid black and white lines in $A$ and $B$ are the stage elevations reached by a flow of $227 \mathrm{~m}^{3} / \mathrm{s}$ and $708 \mathrm{~m}^{3} / \mathrm{s}$, respectively. The dashed blue line in $C$ is the computational boundary described in figure 2 . Flow in the main channel is right to left. The maps are inset on 2002 aerial photography. Northing and easting on the map projection is 1983 Arizona State Plane, central zone. 

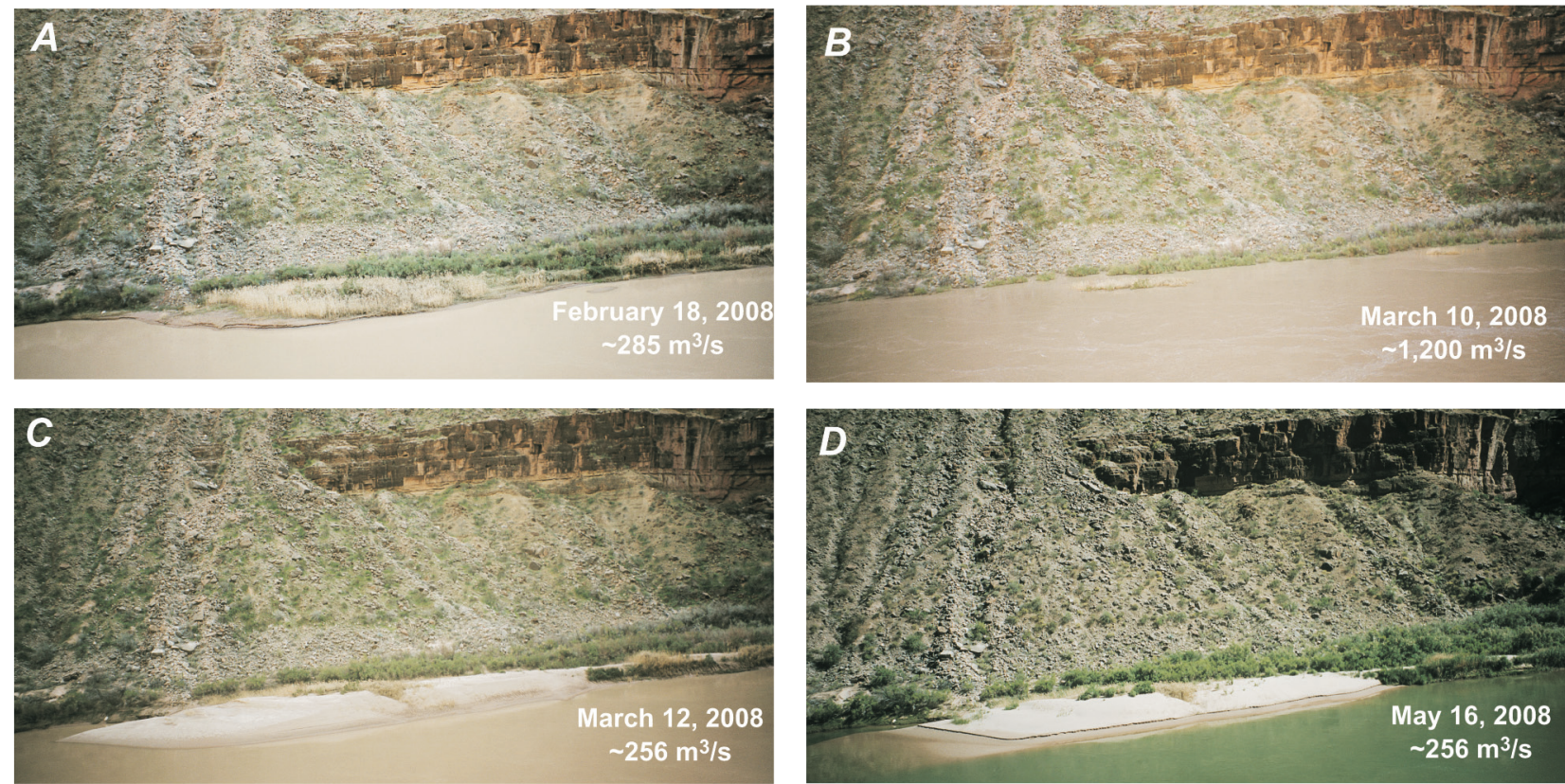

Figure 7. Selected daily photographs of the reattachment bar at site 172L. Flow in main channel is from left to right. The date and estimated discharges based on travel time between USGS stream-flow gaging stations on the Colorado River are given for each. $A, A$ large, vegetated mid and high-elevation bar is present. $B$, The extent and height of site inundation by the $2008 \mathrm{HFE}$ is shown. $C$, Post-HFE deposition. $D$, The bar was relatively stable after the onset of a higher flow regime (April 15, 2008).

A Areal and volumetric changes in eddy elevation
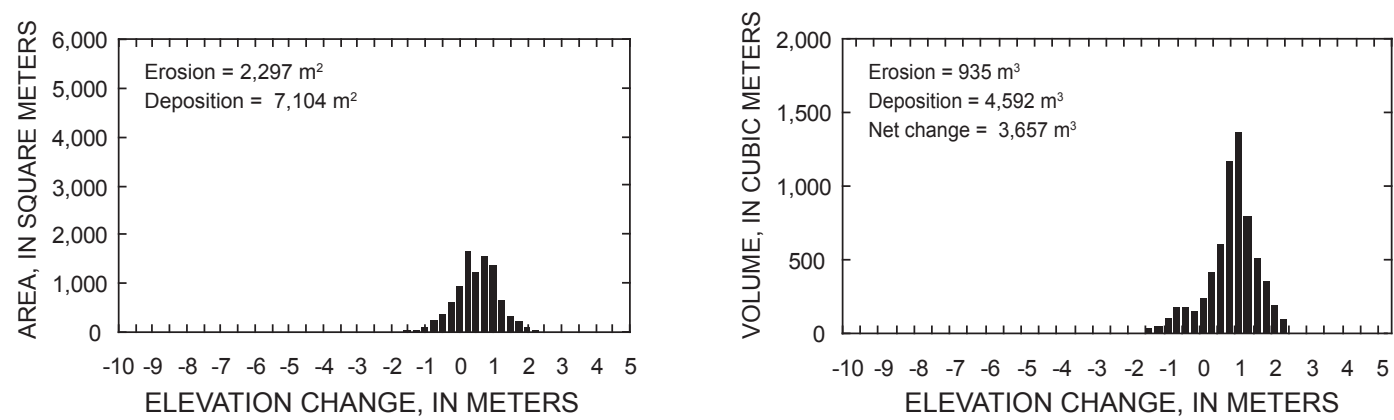

$B$ Areal and volumetric changes in channel elevation
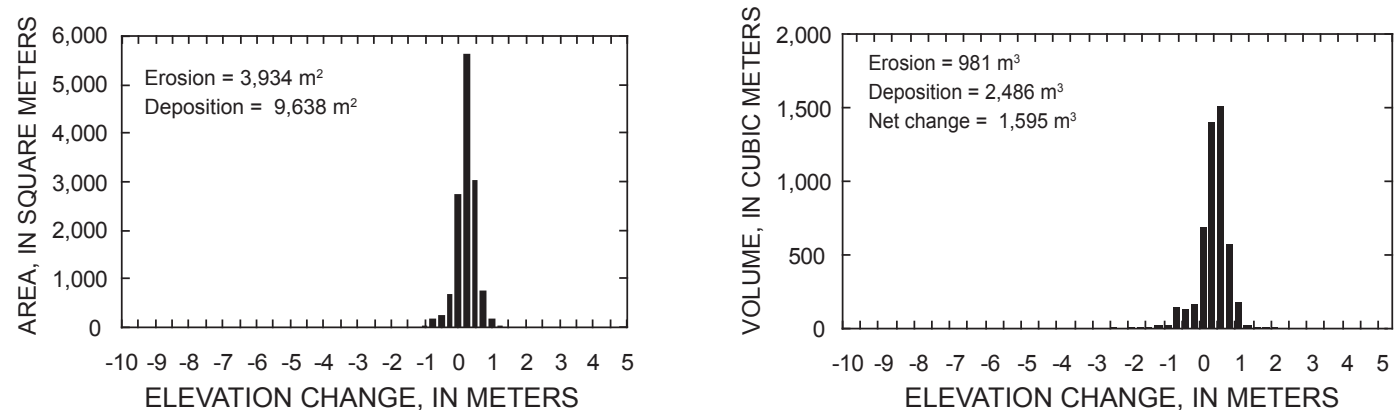

Figure 8. Areal and volumetric elevation-change distributions from the erosion-deposition map at site $172 \mathrm{~L}$ shown in figure $6 C$. $A$, Total eddy. $B$, Main channel. 


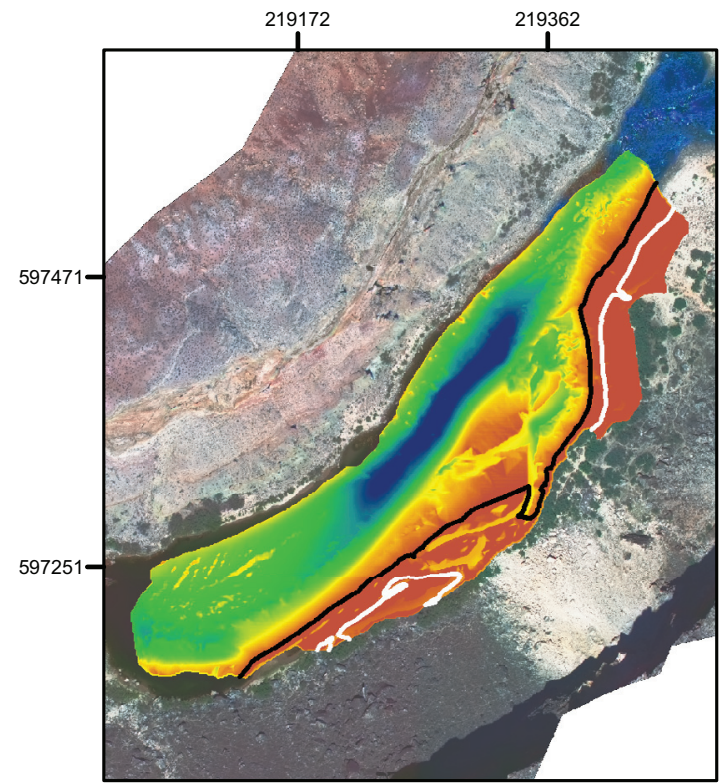

A Pre-2008 HFE DEM

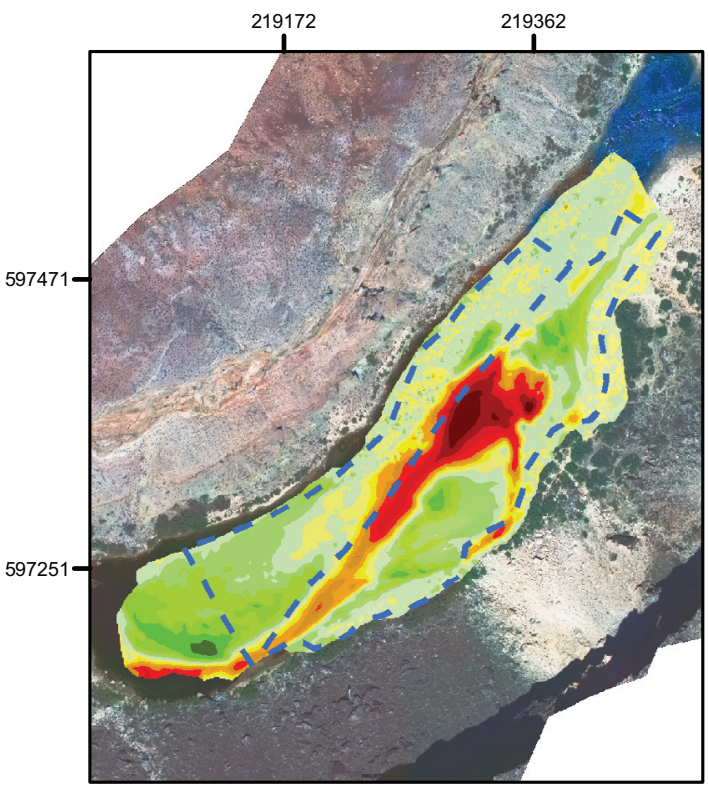

C Erosion-deposition map

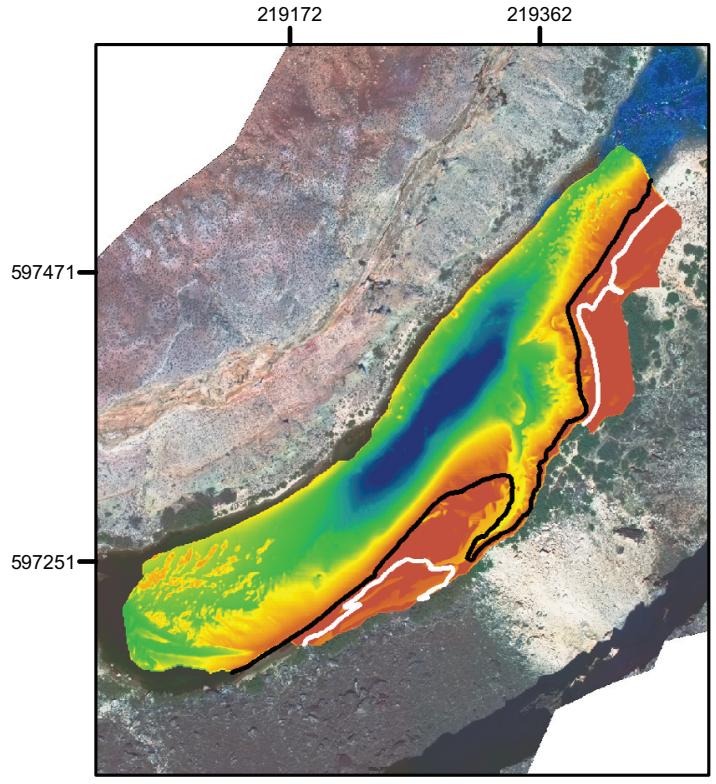

B Post-2008 HFE DEM

\section{Explanation}

DEM - Elevation in $A$ and $B$

(m)
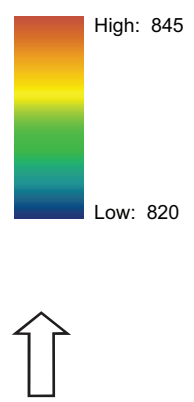

N
Elevation Change in C

(m)

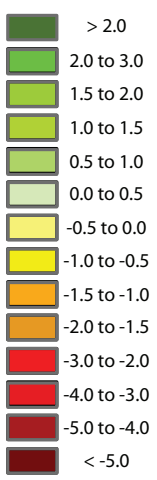

$0 \quad 50 \quad 100$ meters

Figure 9. Comparison of repeat topographic and bathymetric surveys collected at site 44L illustrating a Style 2 sandbar response. $A$, Pre-HFE digital elevation model (DEM). $B$, Post-HFE DEM. $C$, The DEMs were differenced against each other to produce a map of spatially distributed elevation change. The solid black and white lines in $A$ and $B$ are the stage elevations reached by a flow of $227 \mathrm{~m}^{3} / \mathrm{s}$ and $708 \mathrm{~m}^{3} / \mathrm{s}$, respectively. The dashed blue line in $C$ is the computational boundary described in figure 2. Flow in the main channel is from upper right to lower left. The maps are inset on 2002 aerial photography. Northing and easting on the map projection is 1983 Arizona State Plane, central zone. 


\section{Separation bar}
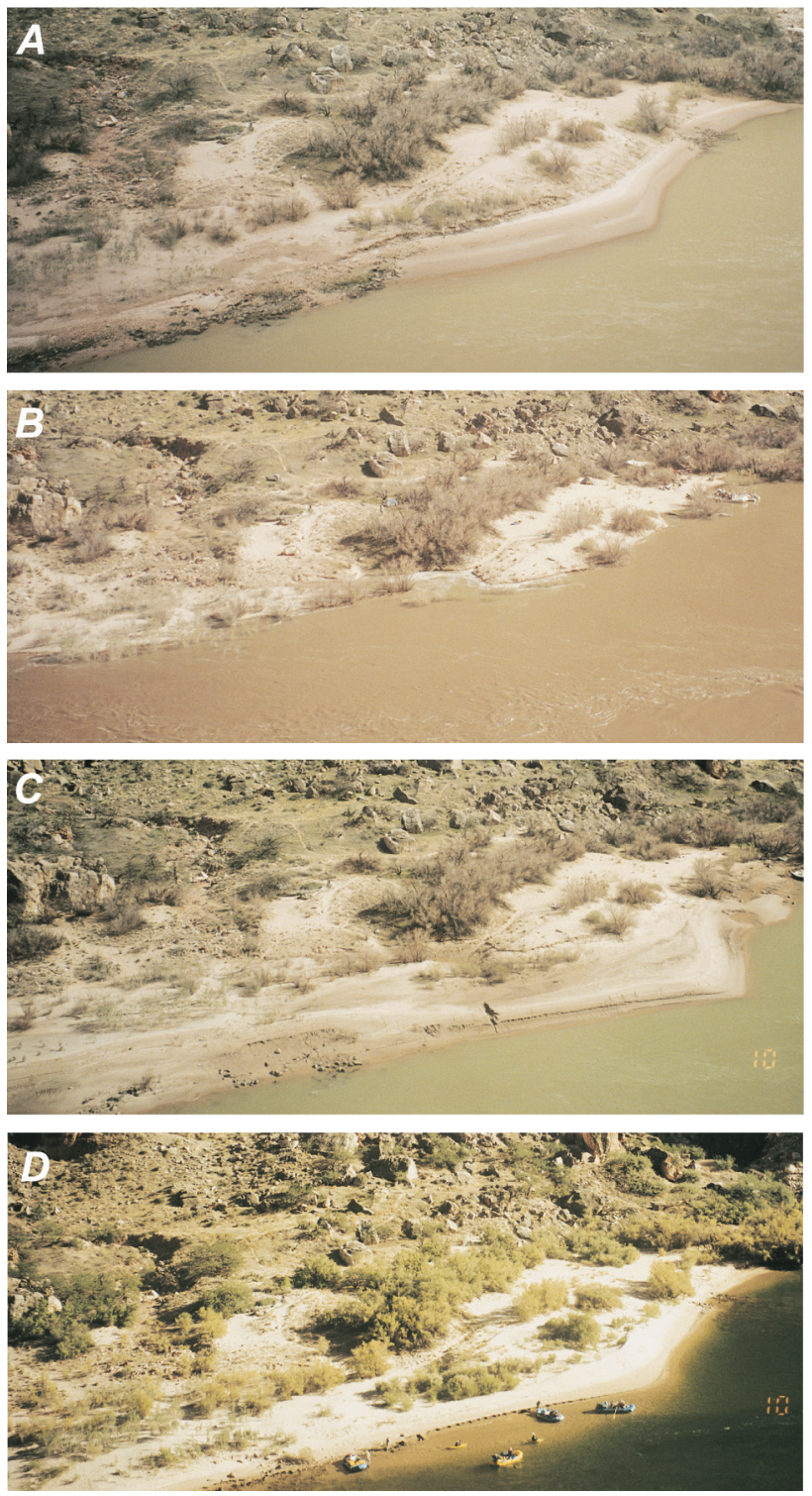

Reattachment bar
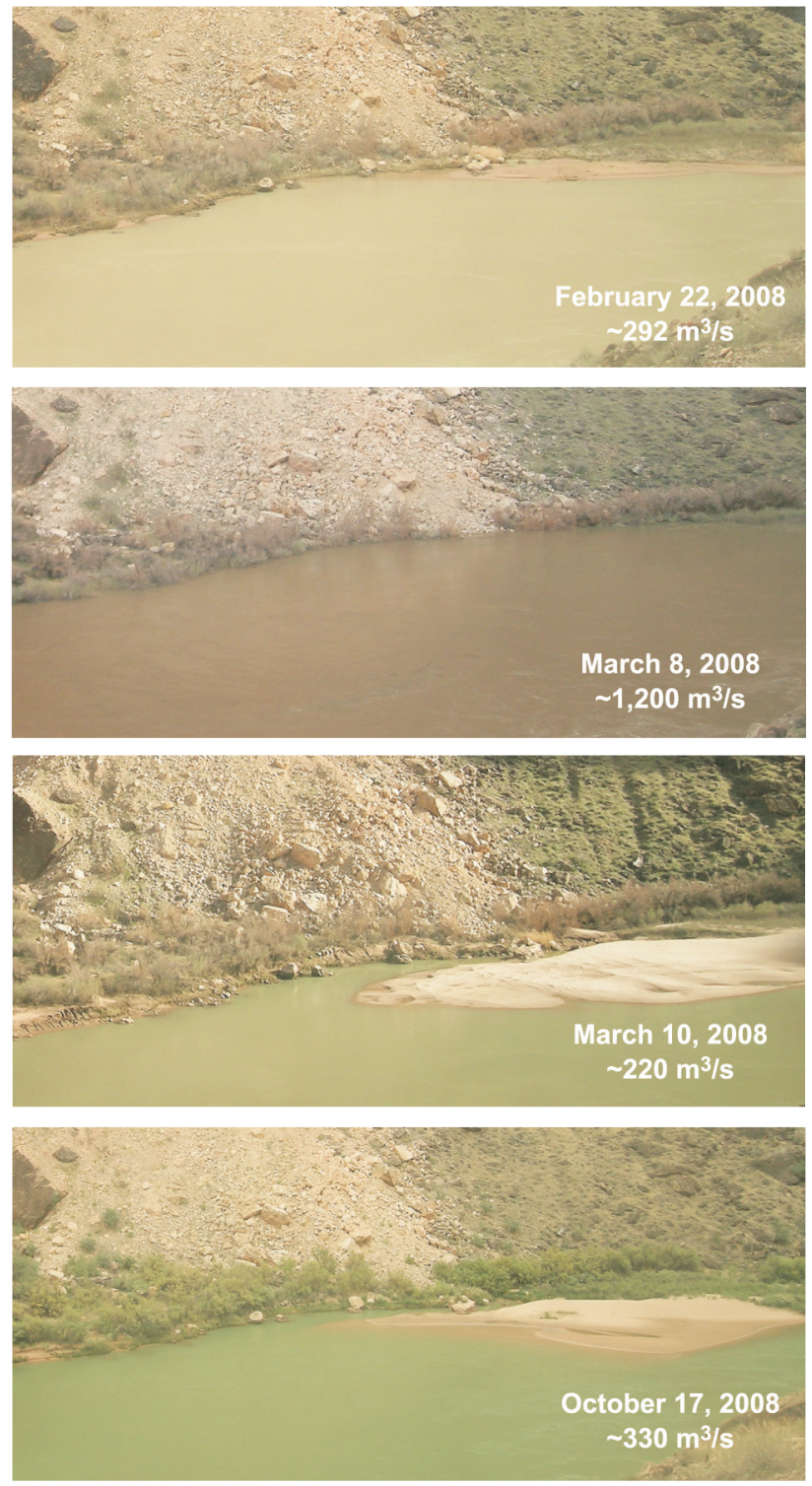

Figure 10. Selected daily photographs of the sandbars at site 44L. In each sequence the separation bar is shown on the left and the reattachment bar is to the right. Flow in main channel is from left to right. The indicated discharges are estimates based on travel time between USGS stream-flow gaging stations on the Colorado River. A, Pre-2008 HFE. Note the rocky shoreline on the upstream end of the separation bar and thick vegetation at high-elevation on the reattachment bar. $B$, The extent and height of site inundation by the $2008 \mathrm{HFE}$ is shown. $C$, Post-2008 HFE response. $D$, Erosion in the following months. 
end of the eddy and in the adjacent channel, where more than $2 \mathrm{~m}$ of sand deposited (figs. 15C, 16C). Erosion occurred elsewhere, especially in the upstream half of the eddy and in parts of the channel (fig. 15C). Scour of the reattachment-bar platform occurred to a depth of more than $5 \mathrm{~m}$, resulting in a decrease in volume of sand above reference stage of 1,165 $\mathrm{m}^{3}$. The volume of sand in the eddy above reference stage decreased to 23 percent of maximum. The adjacent main channel was also scoured to depths exceeding $5 \mathrm{~m}$. The scour hole at the upstream end of the site deepened and lengthened. Erosion also occurred at the exit slope, where much of the dune field was removed (fig. 15B).

The distributions of areal and volumetric change show that in nearly equal areas of the eddy $\left(\sim 2,000 \mathrm{~m}^{2}\right)$ there was as much as $5.5 \mathrm{~m}$ of erosion and $2 \mathrm{~m}$ of deposition (fig. 17A). In contrast, a larger part of the channel, about $6,500 \mathrm{~m}^{2}$ was eroded about 3 to $5 \mathrm{~m}$, and there was 1 to $2 \mathrm{~m}$ of sand deposited over a smaller area of the bed (fig. 17B). The greatest volume of sediment eroded from the eddy occurred where there was erosion of between 5 and $6 \mathrm{~m}$ of sand, and the greatest aggradation occurred where there was deposition of more than $1.5 \mathrm{~m}$ of sand. A scour depth of more than $3 \mathrm{~m}$ occurred over 43 percent of the entire site area, above and below reference stage. There was a total of $13,860 \mathrm{~m}^{3}$ of net erosion in the eddy and $40,131 \mathrm{~m}^{3}$ of net erosion in the channel, and the site as a whole lost $53,991 \mathrm{~m}^{3}$ of sand.

\section{Spatial Pattern of Topographic Response}

The three primary response styles occurred to different extents in different parts of Marble and Grand Canyons (fig. 18A). Response Style 1 (increase in sand volume at all elevations) occurred most commonly in Grand Canyon, and Style 2 (increase in sand volume above reference stage and decrease below reference stage) was most prevalent in Marble Canyon (fig. 18A). Style 3 (net decrease in sand volume above and below reference stage) occurred at least once in every sediment-transport-flux reach, but less commonly in CGC and WGC than in UMC and LMC. The Style 4 response (decrease in sand volume above reference

\section{A Areal and volumetric changes in eddy elevation}
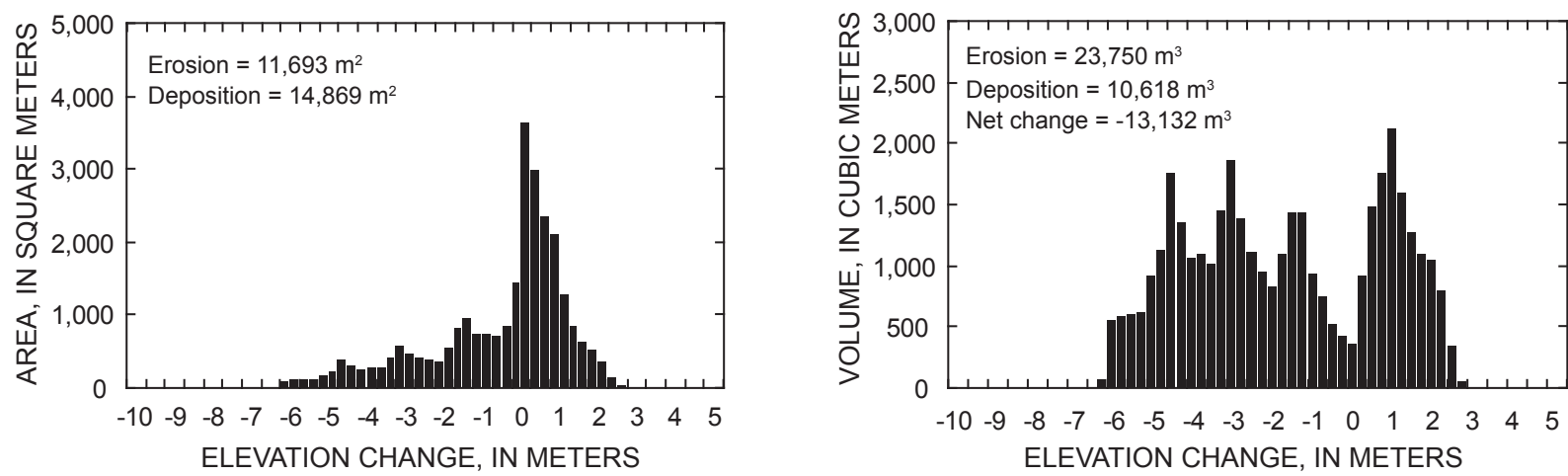

\section{$B$ Areal and volumetric changes in channel elevation}
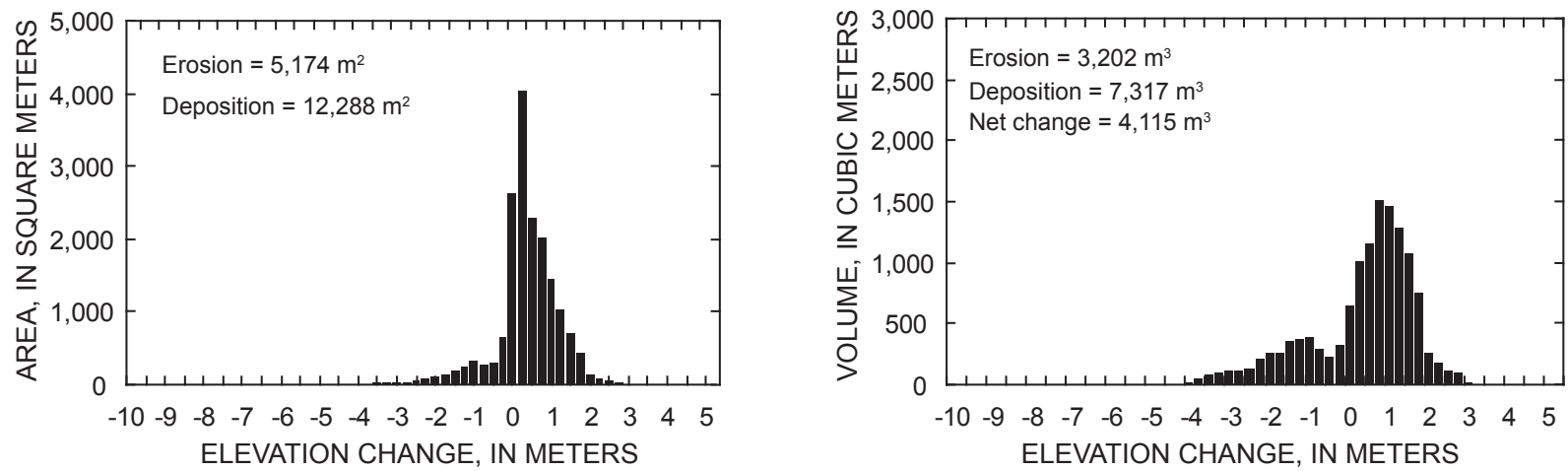

Figure 11. Areal and volumetric elevation-change distributions from the erosion-deposition map at site 44L shown in figure $9 C$. $A$, Total eddy. $B$, Main channel. 


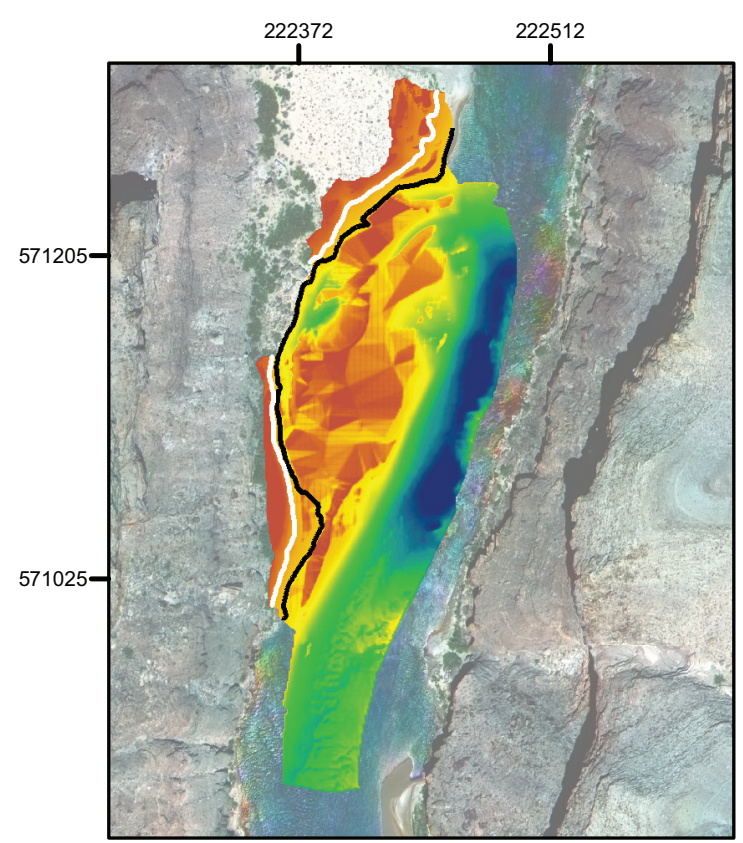

A Pre-2008 HFE DEM

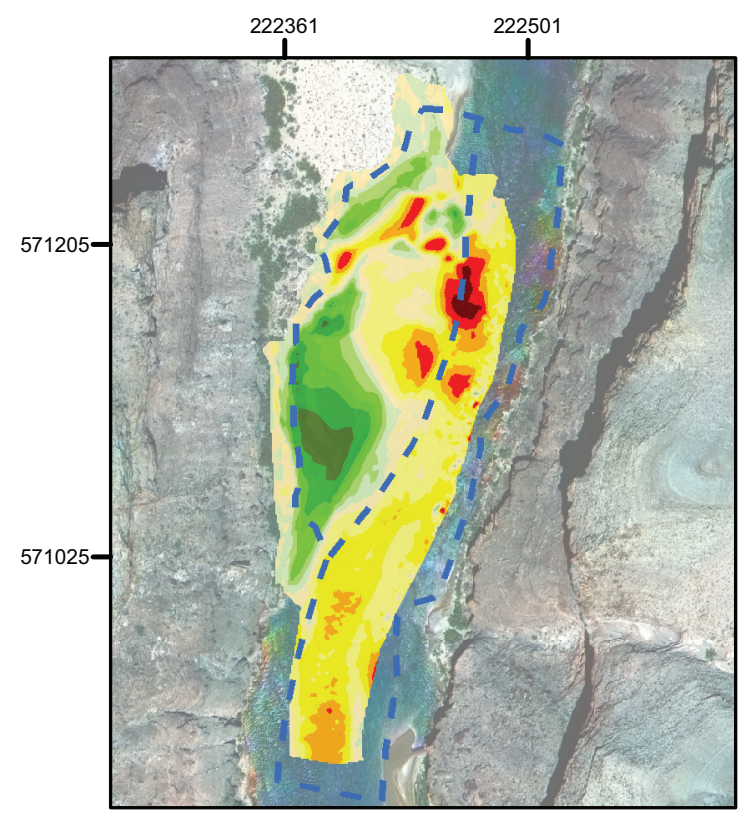

C Erosion-deposition map

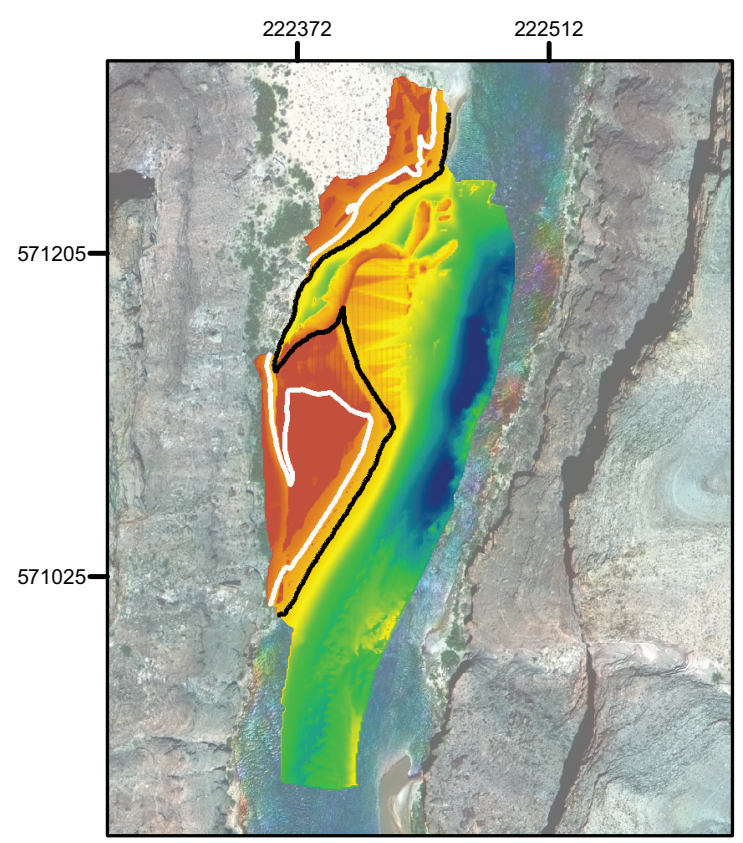

B Post-2008 HFE DEM

\section{Explanation}

DEM - Elevation in $A$ and $B$ (m)

Elevation Change in $C$

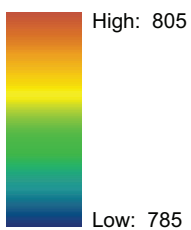

$(\mathrm{m})$

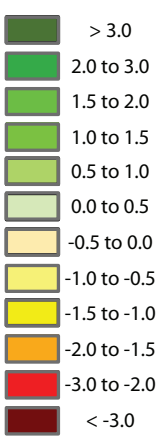

0

$50 \quad 100$ meters

Figure 12. Comparison of repeat topographic and bathymetric surveys collected at $65 R$ illustrating a variant of Style 2 response. Flow in the main channel is from top to bottom. The maps are inset on 2002 aerial photography. Northing and easting on the map projection is 1983 Arizona State Plane, central zone. A, Pre-2008 HFE digital elevation model (DEM). $B$, Post-2008 HFE DEM. $C$, The DEMs were differenced against each other to produce a map of spatially distributed elevation change. The solid black and white lines in $A$ and $B$ are the stage elevations reached by a flow of $227 \mathrm{~m}^{3} / \mathrm{s}$ and $708 \mathrm{~m}^{3} / \mathrm{s}$, respectively. The dashed blue line in $C$ is the computational boundary described in figure 2 . 
stage and increase below reference stage) occurred at only one site in EGC.

Despite downstream increase in the prevalence of Style 1 , sandbars in the high-elevation zone throughout Marble and Grand Canyons increased in thickness to about the same degree. However, the styles of the eddy and total-site responses were more variable. The median increase in sandbar thickness above reference stage was similar in all reaches (fig. 18B). In general, the occurrence of Style 1 (widespreaddeposition) increased longitudinally downstream, suggesting more sand was deposited than eroded. The variability between individual sites was greater in Marble Canyon and EGC; however, it is unclear whether that increased variability is the result of differences in behavior in those reaches or of greater study-site density. In contrast to the similarity between reaches of the median deposit response above the reference stage, the total-eddy median change in sandbar thickness increased from negative values in Marble Canyon to positive values downstream in Grand Canyon. However, the median change in total-eddy sandbar thickness in CGC was about half that in EGC and WGC. In contrast, the median change in total-site sand thickness progressively increased from $0.60 \mathrm{~m}$ of net erosion in upper Marble Canyon to $0.23 \mathrm{~m}$ of net deposition in western Grand Canyon (fig. 18B).

\section{Longevity: Changes from April to October 2008}

Sandbar erosion rates were greatest in the first 2 months following the $2008 \mathrm{HFE}$ and declined thereafter, consistent with observations made following the 1996 HFE (Hazel and others, 1999). Between cessation of the high flow on March 10 and the post-2008 HFE measurements on April 15, 2008, dam releases consisted of fluctuating flows with daily peaks of 390 $\mathrm{m}^{3} / \mathrm{s}$ or less (fig. 3). During this period most newly deposited sandbars were stable or eroded gradually (table 4). On April 15,2008 , release volumes increased and daily peak flows were between 425 and $462 \mathrm{~m}^{3} / \mathrm{s}$. The daily photographs show that the rate of bar erosion accelerated at 5 out of 32 sites monitored by remote camera (table 4; fig. 19). The bulk of this erosion occurred at laterally migrating cutbanks in the new deposits (figs. $10 D, 13 C, 16 D, 19 C-E$ ). These observations are consistent with the sandbar surveys, which show substantial decreases in sandbar thickness above the reference stage in the 7 weeks between the post-2008 HFE surveys, conducted in late March and early April 2008, and the surveys conducted in May (fig. 20). During this 7-week period, the sandbar volume above reference stage eroded at a median rate of $5.3 \mathrm{~m}^{3} /$ day. From May to October 2008, the median erosion rate declined to $2.2 \mathrm{~m}^{3} /$ day. The greatest erosion rate was observed at site $65 \mathrm{R}$, where the deposit above the reference stage eroded at a rate of $85 \mathrm{~m}^{3} /$ day between April 3 and May 24, 2008. A small cutbank at the site was $0.2 \mathrm{~m}$ high when measured on April 3 (fig. 13A). By the May 24 survey, the cutbank had migrated 10 to $15 \mathrm{~m}$ into the bar and was approximately $0.4 \mathrm{~m}$ high (fig. 13B). Between the May and the October 2008 survey, the
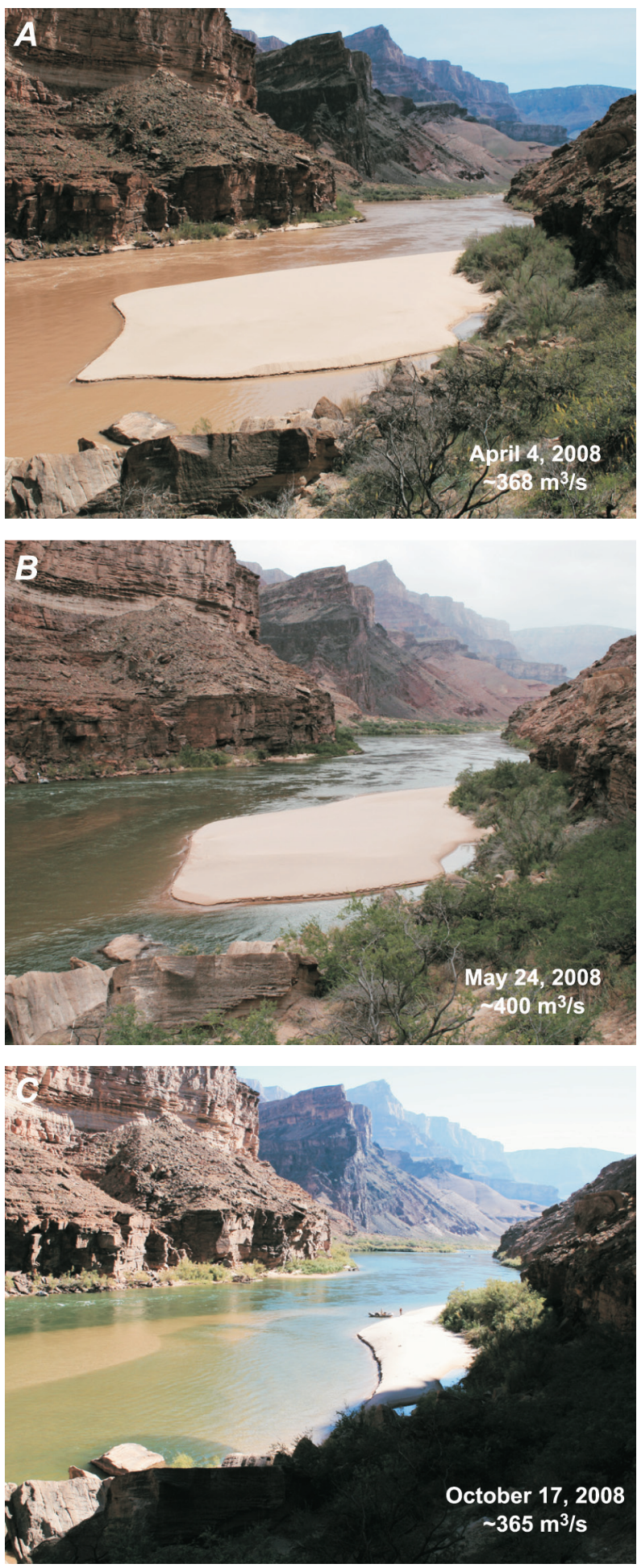

Figure 13. Selected daily photographs of the reattachment bar at site $65 \mathrm{R}$. Flow in main channel is from bottom left to upper right. The indicated discharges are estimates based on travel time between USGS streamflow gaging stations on the Colorado River. $A$, The newly deposited reattachment bar. $B$, Onset of post-flood erosion. $C$, Extensive lateral cutbank retreat. 
Table 4. Observations of erosion and deposition from repeat photography at sites along the Colorado River in Marble and Grand Canyons.

[These changes are our observations based on available images from the fixed-camera network taken between April and October 2008. S, bar was stable. GD, general deposition. GE, gradual erosion. RE, rapid erosion over a period ranging from 1 day to 2 weeks. -, no images were available because of camera failure or the system was tampered with. Site ID is river mile (RM) location based on the RM centerline (U.S. Geological Survey, 2006) downstream from Lees Ferry (river mile 0) in Grand Canyon National Park. The descriptors " $L$ " and "R" denote the location of the emergent sandbar on left and right sides of the river, respectively, facing downstream.]

\begin{tabular}{|c|c|c|c|c|c|}
\hline \multirow{2}{*}{$\begin{array}{l}\text { Site } \\
\text { ID }\end{array}$} & \multicolumn{4}{|c|}{ Observation interval } & \multirow{2}{*}{ Notes } \\
\hline & Feb. -2008 HFE & $\begin{array}{l}2008 \\
\text { HFE- } \\
\text { April }\end{array}$ & $\begin{array}{l}\text { April- } \\
\text { May }\end{array}$ & May-0ct & \\
\hline $3 \mathrm{~L}$ & $\mathrm{~S}$ & $\mathrm{~S}$ & $\mathrm{~S}$ & GD & $\begin{array}{l}\text { Minor erosion by late April. Deposition at low elevation } \\
\text { upstream from the deposit. }\end{array}$ \\
\hline $8 \mathrm{~L}$ & $\mathrm{~S}$ & $\mathrm{~S}$ & GE & $\mathrm{S}$ & \\
\hline $16 \mathrm{~L}$ & $\mathrm{~S}$ & $\mathrm{~S}$ & GE & GE & $\begin{array}{l}\text { Cutbank retreat. Surface modified by wind deflation on } \\
\text { downstream end and aeolian dune development on } \\
\text { upstream end. }\end{array}$ \\
\hline $22 \mathrm{R}$ & $\mathrm{S}$ & $\mathrm{S}$ & GE & GE & $\begin{array}{l}\text { Gradual sustained erosion by cutbank retreat during all } \\
\text { months. }\end{array}$ \\
\hline $30 \mathrm{R}$ & $\mathrm{S}$ & - & GE & $\mathrm{RE}$ & Mass failure of about half the bar platform on $6 / 3-6 / 4$. \\
\hline $41 \mathrm{R}$ & $\mathrm{S}$ & - & GE & $\mathrm{S}$ & Cutbank retreat. \\
\hline $44 \mathrm{~L}$ & $\mathrm{~S}$ & GE & GE & GE & Cutbank retreat. \\
\hline $45 \mathrm{~L}$ & $\mathrm{~S}$ & GE & RE & $\mathrm{RE}$ & Rapid initial cutbank retreat with rates slowing by July. \\
\hline $47 \mathrm{R}$ & $\mathrm{S}$ & $\mathrm{S}$ & GE & GE & \\
\hline $50 \mathrm{R}$ & $\mathrm{S}$ & - & $\mathrm{S}$ & $\mathrm{S}$ & \\
\hline $51 \mathrm{~L}$ & $\mathrm{~S}$ & $\mathrm{~S}$ & $\mathrm{~S}$ & $\mathrm{~S}$ & Very little new deposition to erode. \\
\hline $55 \mathrm{R}$ & $\mathrm{S}$ & - & $\mathrm{S}$ & $\mathrm{S}$ & \\
\hline $58 \mathrm{R}$ & $\mathrm{S}$ & GE & RE & $\mathrm{S}$ & $\begin{array}{l}\text { Rapid erosion } 4 / 15-4 / 16 \text {. } \\
\text { Cutbank retreat. }\end{array}$ \\
\hline $66 \mathrm{~L}$ & $\mathrm{~S}$ & $\mathrm{~S}$ & GE & GE & $\begin{array}{l}\text { Cutbank development and evidence of wind deflation by } \\
\text { April. }\end{array}$ \\
\hline $68 \mathrm{R}$ & - & RE & - & $\mathrm{S}$ & $\begin{array}{l}\text { Rapid erosion starting } 4 / 17 \text { via large-scale cutbank retreat. } \\
\text { New deposit on upstream end mostly eroded by } 5 / 8 \text {. }\end{array}$ \\
\hline $70 \mathrm{R}$ & $\mathrm{S}$ & $\mathrm{S}$ & GE & GE & $\begin{array}{l}\text { Cutbank retreat on the downstream end and formation of a } \\
\text { large aeolian dune formation on the upstream end. }\end{array}$ \\
\hline $81 \mathrm{~L}$ & $\mathrm{~S}$ & $\mathrm{~S}$ & GE & GE & Large cutbank on downstream end but gradual retreat. \\
\hline $87 \mathrm{~L}$ & $\mathrm{~S}$ & $\mathrm{~S}$ & $\mathrm{~S}$ & $\mathrm{~S}$ & \\
\hline $91 \mathrm{R}$ & GE & GE & $\mathrm{S}$ & $\mathrm{S}$ & $\begin{array}{l}\text { Gully formed on } 2 / 23 \text { followed by a small rapid erosion } \\
\text { event on } 2 / 28 \text {. }\end{array}$ \\
\hline $104 \mathrm{R}$ & $\mathrm{S}$ & $\mathrm{S}$ & GE & - & Minor cutbank development. \\
\hline
\end{tabular}


Table 4. Observations of erosion and deposition from repeat photography at sites along the Colorado River in Marble and Grand Canyons.-Continued

[These changes are our observations based on available images from the fixed-camera network taken between April and October 2008. S, bar was stable. GD, general deposition. GE, gradual erosion. RE, rapid erosion over a period ranging from 1 day to 2 weeks. -, no images were available because of camera failure or the system was tampered with. Site ID is river mile (RM) location based on the RM centerline (U.S. Geological Survey, 2006) downstream from Lees Ferry (river mile 0) in Grand Canyon National Park. The descriptors "L" and "R" denote the location of the emergent sandbar on left and right sides of the river, respectively, facing downstream.]

\begin{tabular}{|c|c|c|c|c|c|}
\hline \multirow{2}{*}{$\begin{array}{l}\text { Site } \\
\text { ID }\end{array}$} & \multicolumn{4}{|c|}{ Observation Interval } & \multirow{2}{*}{ Notes } \\
\hline & Feb. -2008 HFE & $\begin{array}{l}2008 \\
\text { HFE- } \\
\text { April }\end{array}$ & $\begin{array}{l}\text { April- } \\
\text { May }\end{array}$ & May-Oct & \\
\hline 119R & $\mathrm{S}$ & RE & GE & GE & $\begin{array}{l}\text { Cutbank development on downstream end immediately } \\
\text { after } 2008 \text { HFE. Rapid cutbank retreat } 4 / 15-4 / 18 \text {; } \\
\text { gradual cutbank retreat 5/27-7/2. }\end{array}$ \\
\hline $122 \mathrm{R}$ & $\mathrm{S}$ & GE & $\mathrm{S}$ & $\mathrm{S}$ & Cut bank retreat immediately after 2008 HFE. \\
\hline $123 \mathrm{~L}$ & $\mathrm{~S}$ & GE & GE & nc & Gradual cut bank retreat after 2008 HFE. \\
\hline $137 \mathrm{~L}$ & $\mathrm{~S}$ & GE & $\mathrm{RE}$ & $\mathrm{NC}$ & $\begin{array}{l}\text { Gradual cutbank retreat in April followed by rapid cutbank } \\
\text { retreat } 4 / 15-4 / 18 \text {. }\end{array}$ \\
\hline 139R & $\mathrm{S}$ & $\mathrm{S}$ & - & - & \\
\hline $145 \mathrm{~L}$ & $\mathrm{~S}$ & - & $\mathrm{S}$ & - & $\begin{array}{l}\text { 2-m cutbank on downstream end formed immediately after } \\
2008 \text { HFE, but bar mostly stable. }\end{array}$ \\
\hline $172 \mathrm{~L}$ & $\mathrm{~S}$ & $\mathrm{~S}$ & $\mathrm{~S}$ & $\mathrm{~S}$ & Bar stable with rapid regrowth of buried vegetation. \\
\hline $183 \mathrm{R}$ & - & - & GE, RE & - & $\begin{array}{l}\text { Gradual cut bank retreat } 4 / 11-4 / 15 \text {. } \\
\text { Rapid cut bank retreat } 4 / 15-4 / 20 \text {. }\end{array}$ \\
\hline 194R & - & $\mathrm{S}$ & $\mathrm{S}$ & $\mathrm{S}$ & \\
\hline $202 R$ & $\mathrm{~S}$ & $\mathrm{~S}$ & GE, RE & $\mathrm{S}$ & $\begin{array}{l}\text { Gradual cutbank retreat } 4 / 11-5 / 5 \text {. } \\
\text { Rapid cutbank retreat 5/5-5/6. }\end{array}$ \\
\hline $213 \mathrm{~L}$ & - & $\mathrm{S}$ & $\mathrm{S}$ & $\mathrm{S}$ & \\
\hline $225 \mathrm{R}$ & $\mathrm{S}$ & $\mathrm{S}$ & $\mathrm{S}$ & - & Minor bank erosion. \\
\hline
\end{tabular}

cutbank had migrated laterally another 20 to $25 \mathrm{~m}$ and was 0.5 m high (fig. 13C).

Another important process that potentially contributed to decreases in sandbar volume was surface deflation by wind. However, volume changes by surface deflation can also be offset by the deposition of eolian dunes as sand is redistributed to different areas of the bar. Eolian dunes initially measured in May had increased in size and extent by October (Draut and others, 2009, figs. 16-17, 41-42). Despite wind modification of sandbar surfaces, we estimate that the dominant erosional process was that of lateral cutbank retreat at approximately 60 percent of the sites monitored with remote cameras (table 4). Other processes that result in bar erosion (that is, hillslope runoff and debris flows) were observed at one site (166L), where the eddy bar was incised by several distributary channels from
September 2008 flooding in National Canyon, a tributary canyon to the Grand Canyon.

\section{Campsite Area}

Sand deposition associated with the 2008 HFE increased campsite area. At 31 out of the 37 sites where campsite area was measured, the total campsite area (combined mid- and high-elevation zones) increased between the pre- and post2008 HFE measurements (appendix B; table 4). Increases in campsite area were as small as $3 \mathrm{~m}^{2}$, and the greatest increase was more than $2,000 \mathrm{~m}^{2}$ (fig. 21). The median campsite area increased from 263 to $437 \mathrm{~m}^{2}$ (fig. 21). Campsite area increased in both mid- and high-elevation zones (fig. 22). 
Of the six sites where campsite area decreased, the largest decrease was $260 \mathrm{~m}^{2}$.

Post-2008 HFE sandbar erosion resulted in declines in campsite area, particularly in the midelevation zone. Between measurements made in April and the measurements repeated in October 2008, total campsite area decreased at 31 of the 37 sites. The median campsite area decreased from 437 to 319 $\mathrm{m}^{2}$ (fig. 21). Midelevation campsite area in noncritical reaches was less than that measured in February. Despite the erosion measured between April and October, the total campsite area above the reference stage in October 2008 remained larger than the values measured in February 2008 (fig. 22).

To determine the effects of post-2008 HFE deposition and erosion on campsite area, the measured sandbar area and volume changes were compared to campsite area changes (fig. 23). Campsite area changes, including increases between February and April 2008 and decreases that occurred between April and October, were positively correlated with the magnitude of sandbar volume change $\left(r^{2}=0.72\right.$, significant at the 95-percent confidence level). Correlation of changes in campsite area and sandbar area were not as strong $\left(r^{2}=0.27\right)$. Sandbar volume has a better correlation with campsite area than with sandbar area because increases in volume frequently smooth irregular topography and temporarily bury vegetation; both of these processes can increase campsite area without affecting sandbar area.

The topographic changes described in the previous section show that sandbar deposition followed by cutbank retreat and resulting bar volume loss were the primary causes of the increases and then decreases in campsite area. As the result of the $2008 \mathrm{HFE}$, campsite area increased at all sites characterized by Style 1 and 2 responses. Deposition resulted in temporary burial of preexisting, vegetated portions of the sandbars (figs. 7A, 7C) and altered shorelines by covering rocks (figs. $10 \mathrm{~A}, 10 \mathrm{C}$ ). At several sites, campsite area increased dramatically where deposition in eddies created large, flat reattachment bars. For example, midelevation camp area at site $45 \mathrm{~L}$ increased from 0 to $1,148 \mathrm{~m}^{2}$

\section{A Areal and volumetric changes in eddy elevation}
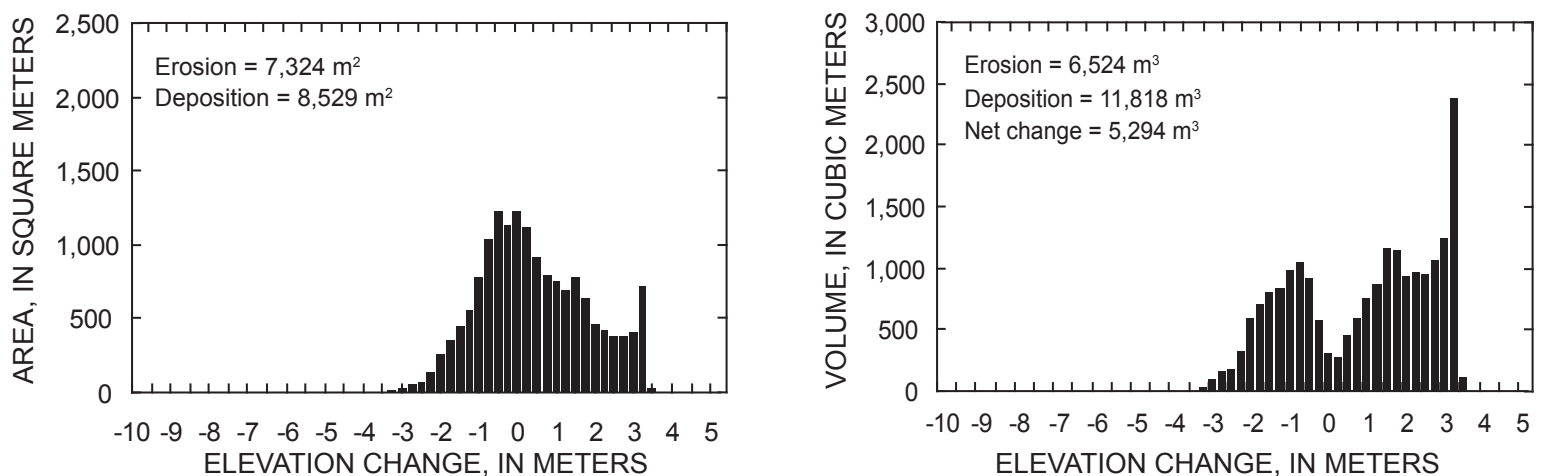

$B$ Areal and volumetric changes in channel elevation
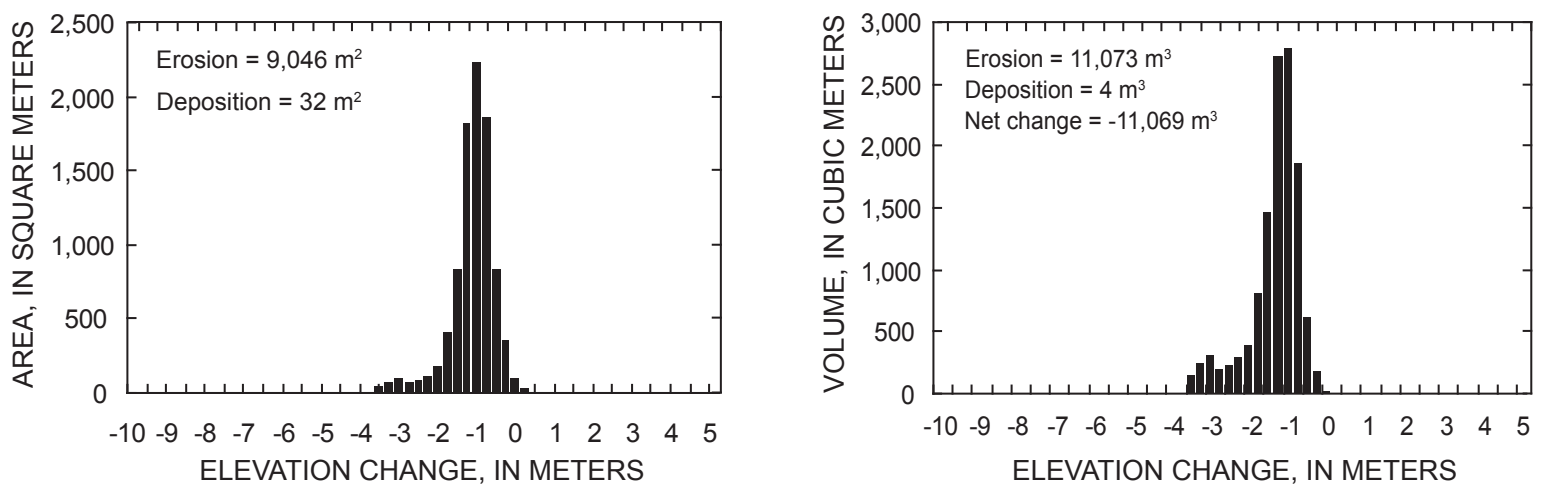

Figure 14. Areal and volumetric elevation-change distributions from the erosion-deposition map at site 65R shown in figure 12C. A, Total eddy. B, Main channel. 


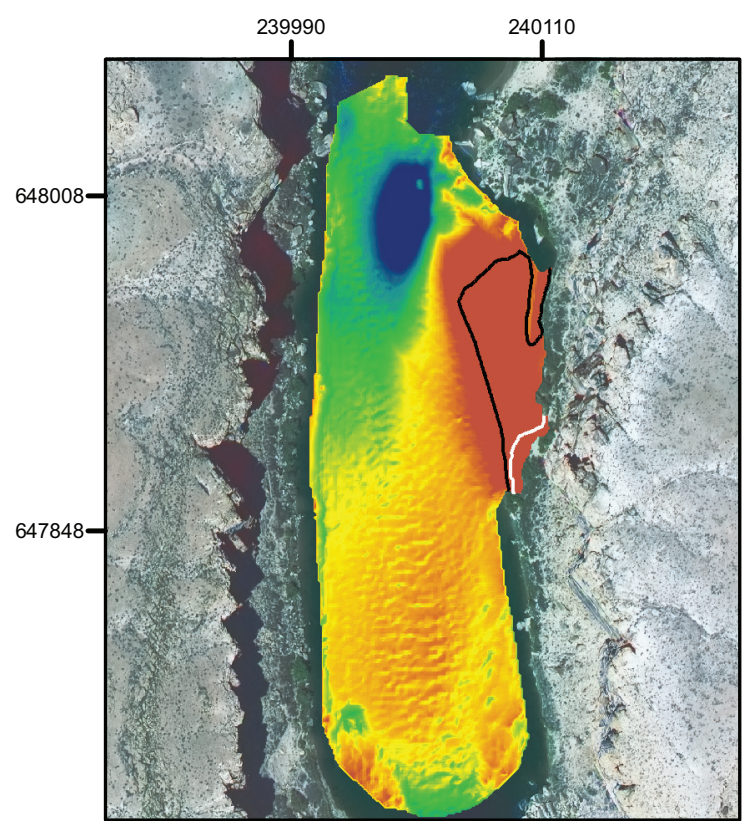

A Pre-2008 HFE DEM

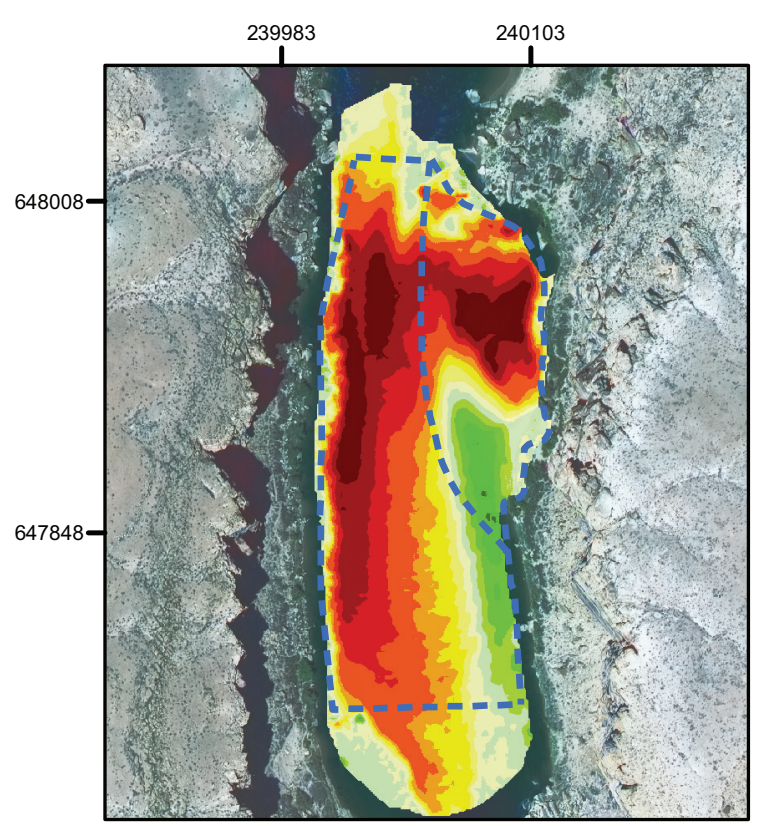

C Erosion-deposition map

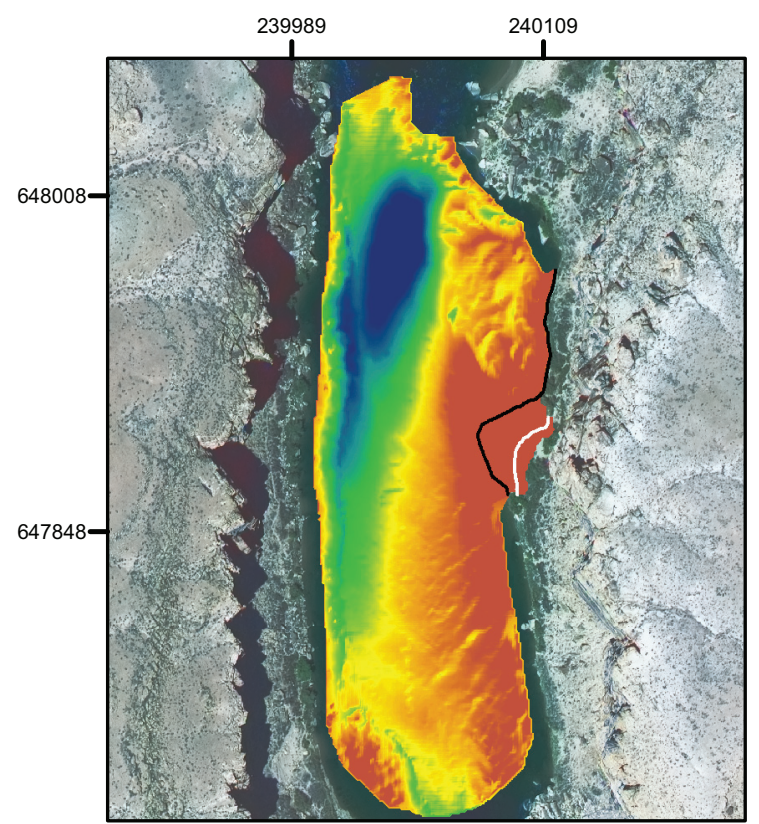

B. Post-2008 HFE DEM

\section{Explanation}

DEM - Elevation in $A$ and $B$

(m)
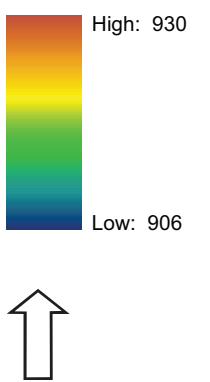

N
Elevation Change in $C$

(m)

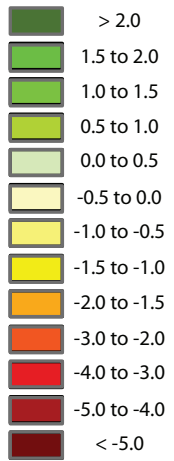

$0 \quad 50 \quad 100$ meters

Figure 15. Comparison of repeat topographic and bathymetric surveys collected at site $3 \mathrm{~L}$. Flow in the main channel is from top to bottom. The maps are inset on 2002 aerial photography. Northing and easting on the map projection is 1983 Arizona State Plane, central zone. A, Pre-HFE digital elevation model (DEM). B, Post-HFE DEM. C, The DEMs were differenced against each other to produce a map of spatially distributed elevation change. The solid black and white lines in $A$ and $B$ are the stage elevations reached by a flow of $227 \mathrm{~m}^{3} / \mathrm{s}$ and $708 \mathrm{~m}^{3} / \mathrm{s}$, respectively. The dashed blue line in $C$ is the computational boundary described in figure 2 . 

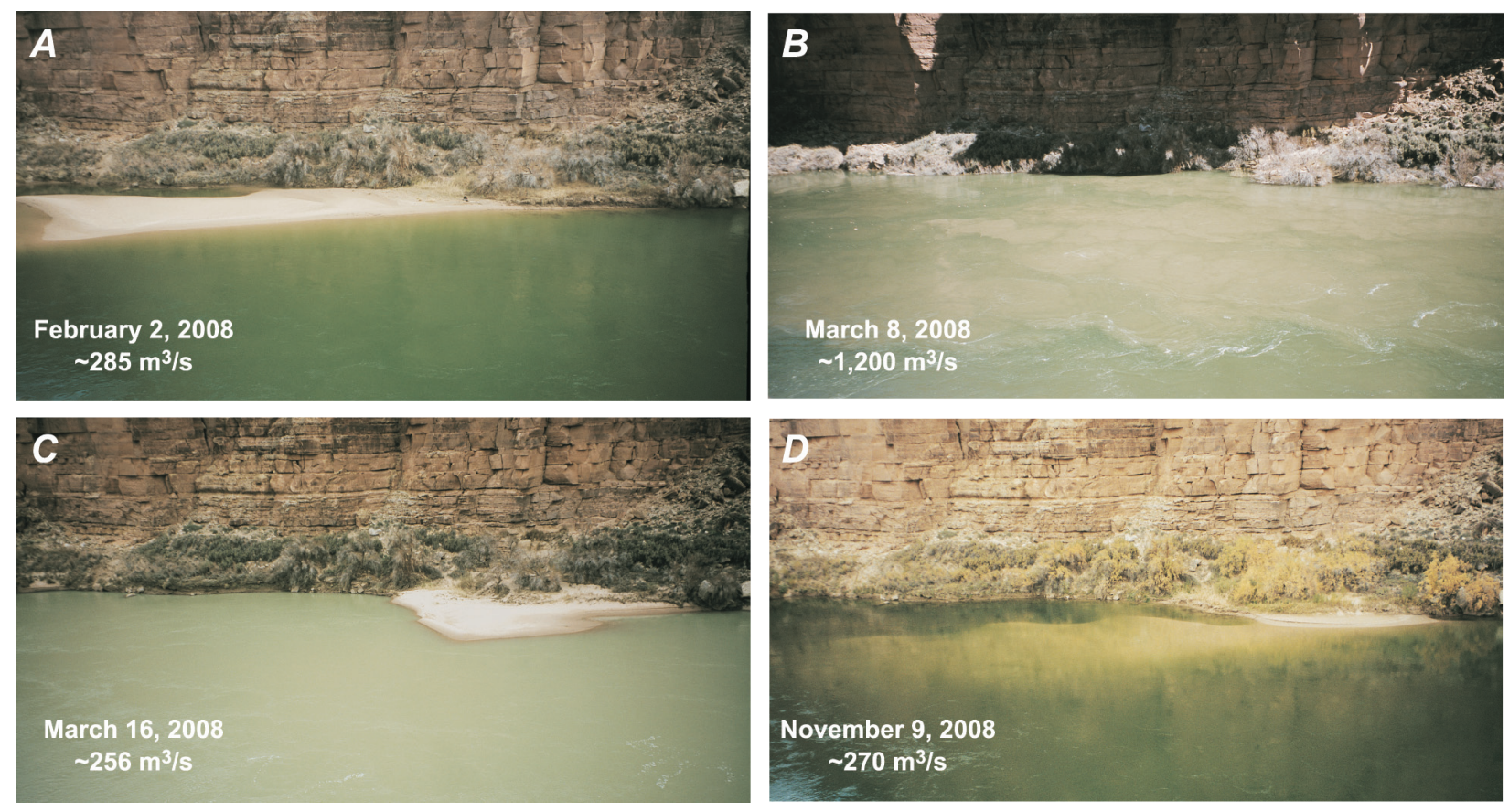

Figure 16. Selected daily photographs of the reattachment bar at site $3 \mathrm{~L}$. Flow in main channel is from left to right. The indicated discharges are estimates based on travel time between USGS stream-flow gaging stations on the Colorado River. $A$, $A$ large, midelevation bar is present. $B$, The extent and height of site inundation by the $2008 \mathrm{HFE}$ is shown. $C$, Upstream erosion and downstream deposition following the 2008 HFE. D, Erosion of the high-elevation bar between April and November 2008.

A Areal and volumetric changes in eddy elevation
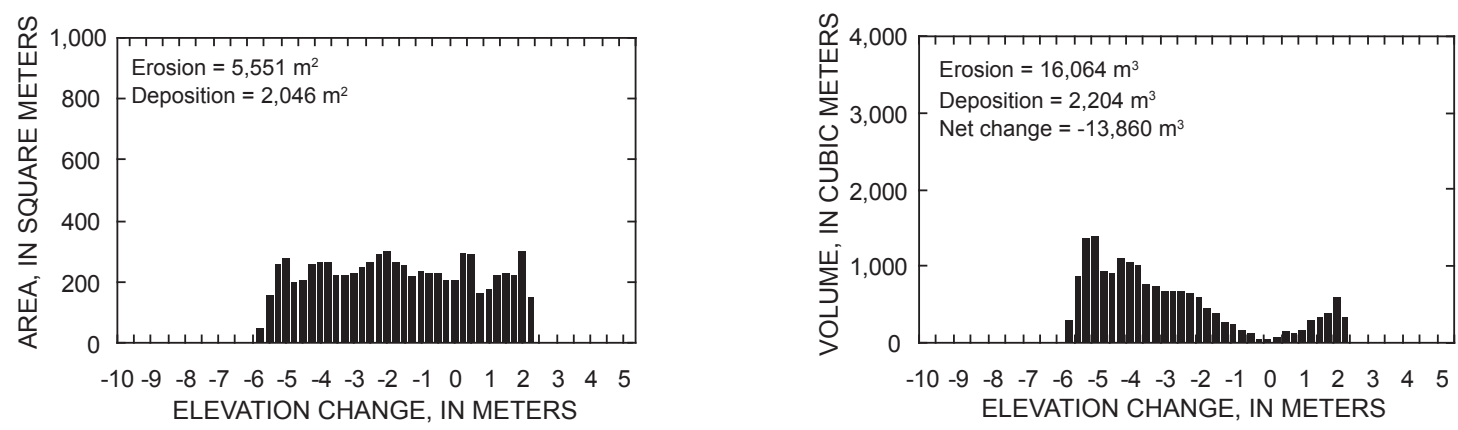

$B$ Areal and volumetric changes in channel elevation
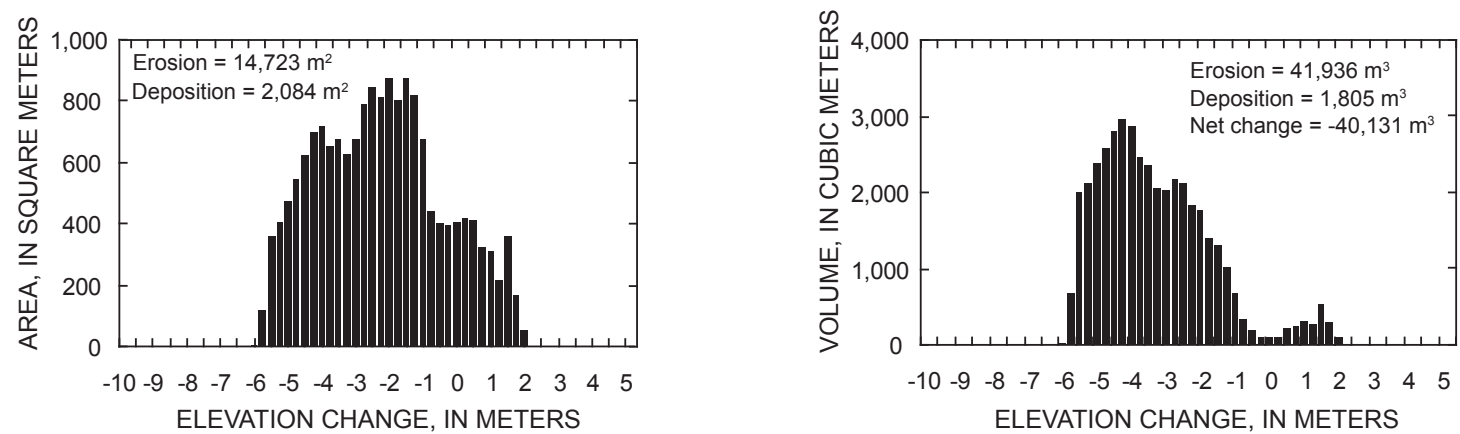

Figure 17. Areal and volumetric elevation-change distributions from the erosion-deposition map at site $3 \mathrm{~L}$ shown in figure $15 C$. $A$, The total eddy. $B$, Main channel. 


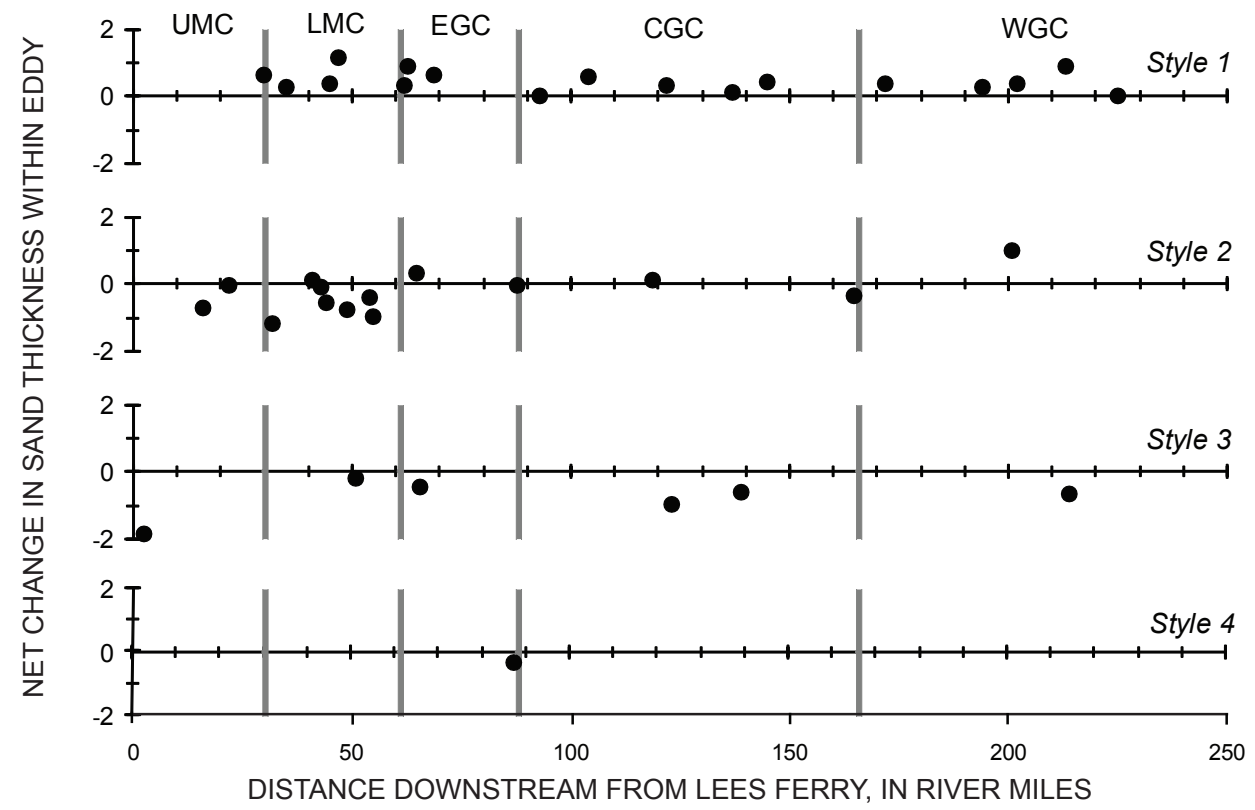

$B$

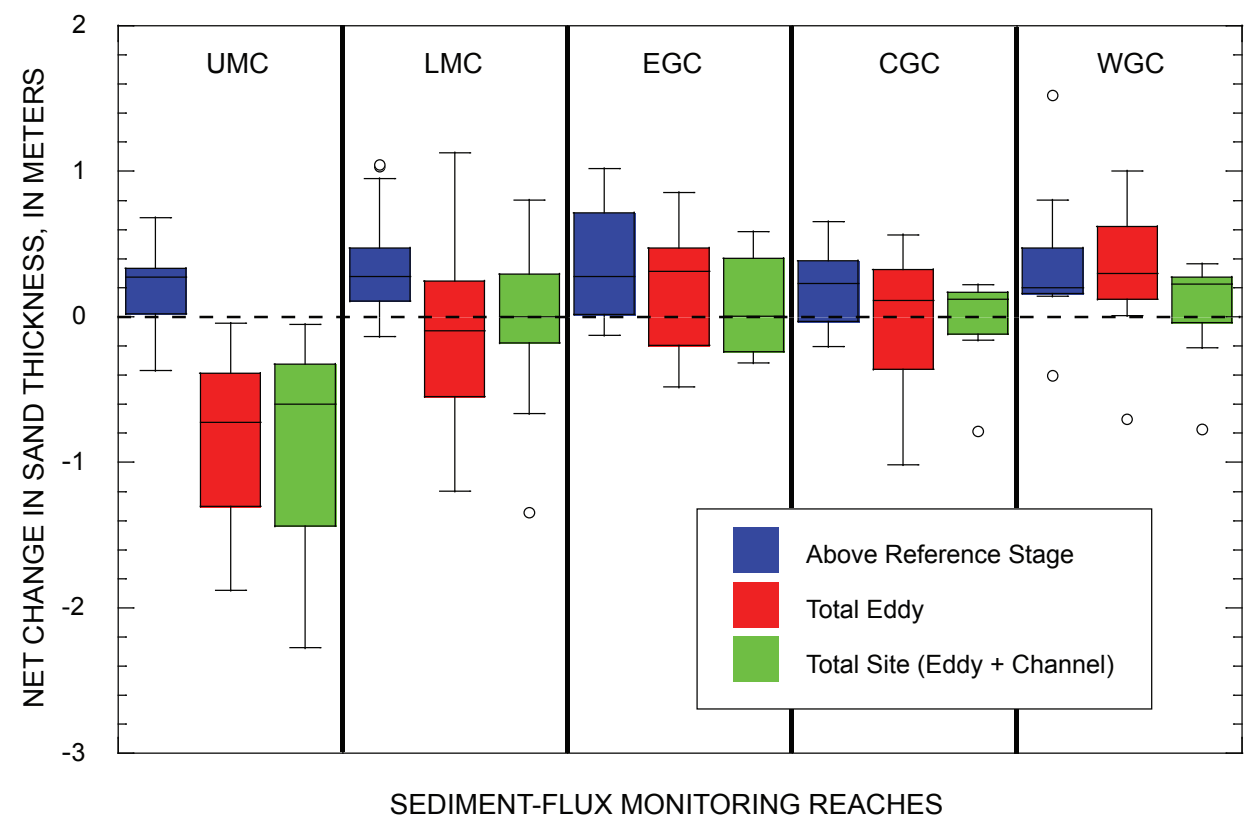

Figure 18. Downstream variations at study sites and sediment-transport-flux monitoring reaches in response to $2008 \mathrm{HFE}$. Upper Marble Canyon (UMC), lower Marble Canyon (LMC), eastern Grand Canyon (EGC), central Grand Canyon (CGC), and western Grand Canyon (WGC) reaches are shown. $A$, Graph showing the distribution of total-eddy net change in thickness of sand for each response style with distance downstream. $B$, Boxplots showing the distribution of change for above-reference-stage, total-eddy, and total-site thickness within the five sediment flux monitoring reaches. A boxplot summarizes the distribution of data by showing the interquartile range (25th percentile to 75th percentile) as the height of the box, the median value as the center line within the box, lines drawn to smallest and largest values within one step (equal to 1.5 times the interquartile range) beyond either end of the box, and outliers (values greater than two steps outside the box) as circles. 
(appendix B; table 4). The large increase in midelevation-zone area and volume that occurred at $65 \mathrm{R}$ is another example of this response (fig. 13A). Decreases in campsite area resulted largely from lateral cutbank retreat. The large decreases in midelevation-zone area at $65 \mathrm{R}$ and $68 \mathrm{R}$ between April and October 2008 are good examples of this process (figs. 13, 19). The development of eolian dunes and the occurrence of surface runoff were also noted as causing campsite area decreases at several sites, but these surface modifications were less significant factors than the erosion associated with cutbank retreat (table 4).

\section{Comparison of Three High-Flow Experiments: 1996, 2004, and 2008}

Following the 2008 HFE, the volume of sand within the study sites was similar to or exceeded the volume of sand that existed following either the 1996 or 2004 HFEs. Cumulative probability distributions of total sand volume following each of the three high flows, expressed as the ratio of the volume measured following the high flow to the volume measured in February 1996, are depicted in figure 24. Although each sediment-transport-flux reach contains sites where the normalized sand volume was less than 1.0 (that is, less than the volume of sand measured in February 1996), the distribution curves for 2008 typically coincide with or are greater than the 1996 and 2004 curves, indicating total-site sand volume was similar or greater in 2008 than for the previous two HFEs. The total sand volume following the 2008 HFE was greater than following the $1996 \mathrm{HFE}$ in all reaches and was similar to the storage condition following the $2004 \mathrm{HFE}$ for the two reaches (UMC and LMC) where total-site sand volume was measured that year. The median values from these distributions are shown for each respective reach in figure $25 \mathrm{~A}$. In contrast to the previous high flows, the median post-2008 HFE normalized sand volume was approximately equal to or greater than 1.0 in all reaches.

The median sand volume above reference stage was similar to or exceeded the volumes following the previous

Figure 19. Photographic sequence at site 68R showing rapid erosion following the change in fluctuating flow regime at Glen Canyon Dam on April 15, 2008, when diurnal peak flows were increased to $425-462 \mathrm{~m}^{3} / \mathrm{s}$. Flow in main channel is from right to left. The indicated discharges are estimates based on travel time between USGS stream-flow gaging stations on the Colorado River. Flow rate at the time of each photograph is indicated. $A$, The new sandbar one day after recession of the 2008 HFE. $B$, Little change evident 35 days later at the onset of the new flow. $C$, A new cutbank appeared within 1 day of arrival of the higher peak flows. $D$, Within 5 days a 1-2 m cutbank was eroding the thicker portion of the deposit. E, Within 10 days a large portion of the new deposit and associated camping area had eroded.
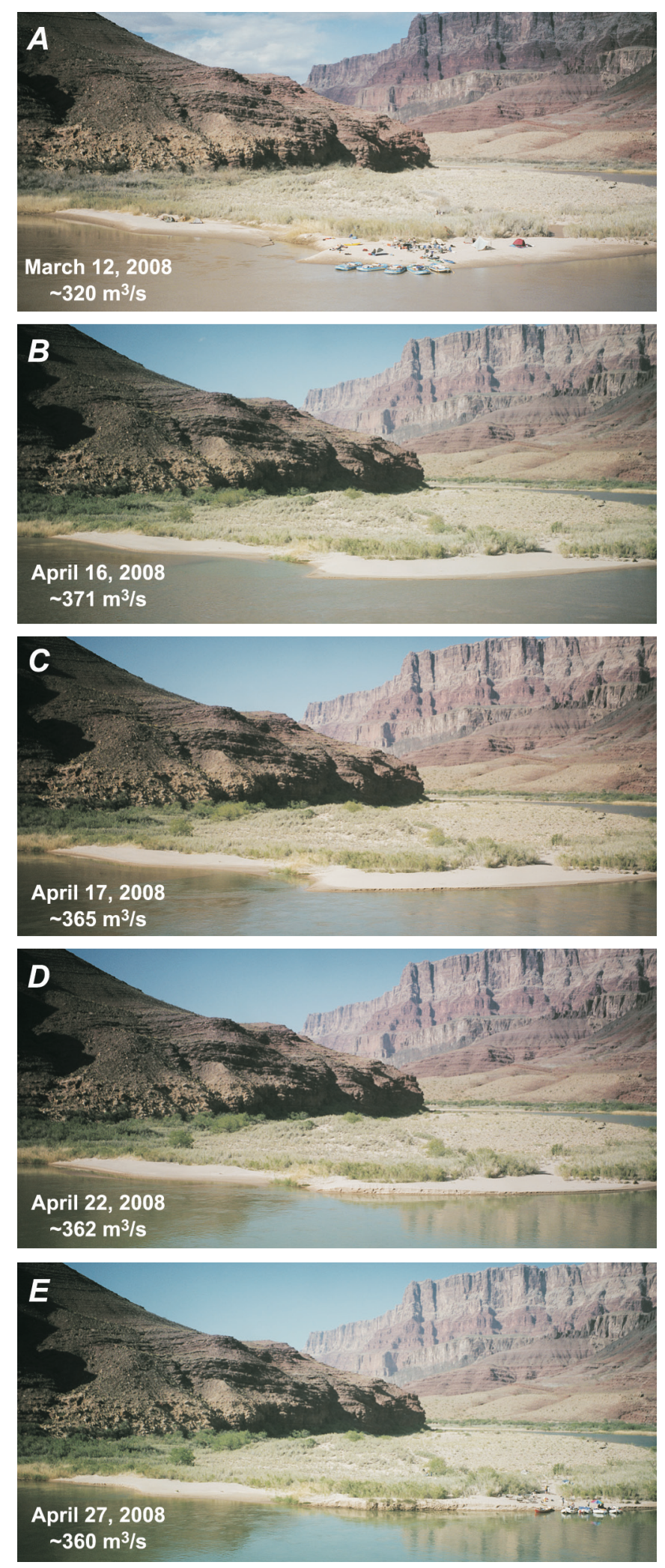


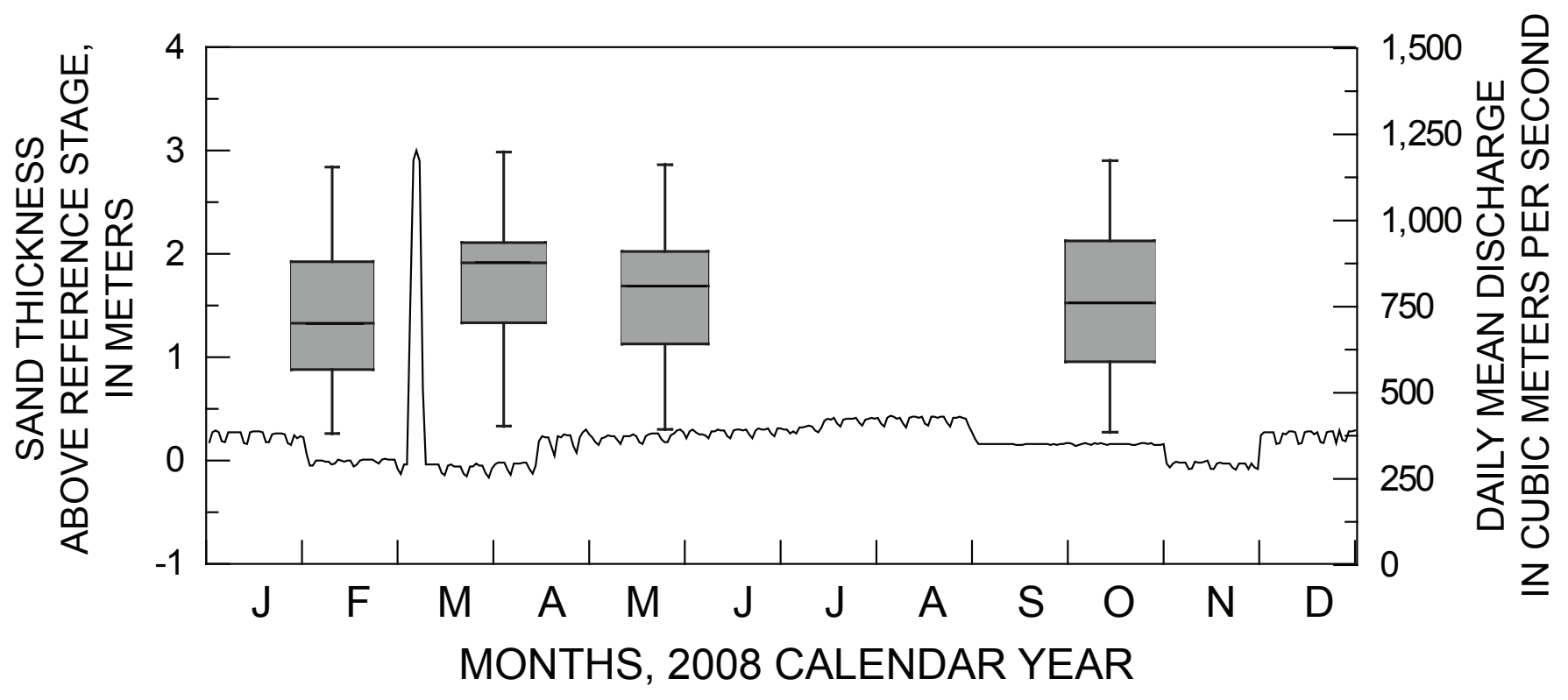

Figure 20. Boxplot showing temporal sequence of deposit thickness above the reference stage compared to daily mean discharge following the $2008 \mathrm{HFE}$. A boxplot summarizes the distribution of data by showing the interquartile range (25th percentile to 75th percentile) as the height of the box, the median value as the center line within the box, lines drawn to smallest and largest values within one step (equal to 1.5 times the interquartile range) beyond either end of the box, and outliers (values greater than two steps outside the box) as circles.

high flows in four out of the five sediment-flux monitoring reaches. Cumulative probability distributions for sand volumes above the reference stage are shown in figure 26. These plots indicate that the volume of sand above the 227$\mathrm{m}^{3} / \mathrm{s}$ stage was slightly less than 1996 and 2004 in UMC and similar or greater in $\mathrm{LMC}, \mathrm{EGC}, \mathrm{CGC}$, and WGC. This pattern is also shown in figure $25 \mathrm{~B}$, where the median values are plotted for each reach. All median values, including that for upper Marble Canyon, are larger than 1.0, indicating that the volume of sand in sandbars above the reference stage was greater following the 2008 HFE than the volume measured before the 1996 HFE.

\section{Discussion and Conclusions}

The 2008 HFE, which followed a period of greatly increased sand supply by the Paria River, resulted in a net increase in the size and volume of sandbars throughout Marble and Grand Canyons. One of the objectives of this third controlled-flood experiment was to evaluate whether a high flow conducted under sediment-enriched conditions could result in sandbar building throughout the system. These sandbar monitoring results show that there was (1) widespread high-elevation deposition and (2) less sand depletion at low elevation within eddies and the main channel than occurred during the two previous HFEs in 1996 and 2004. The net aggradational response also resulted in proportional increases in campsite area in both critical and noncritical reaches.

The increases in eddy deposit thickness above reference stage was similar in all sediment-transport flux reaches, while total-eddy response, strongly influenced by site-specific topographic changes below reference stage, was more variable. The response Style 1, in which all elevations increased in sand volume, occurred more commonly further downstream; upstream reaches had a response typically characterized by high-elevation deposition and low-elevation erosion (Style 2). The median change in total-site deposit thickness increased from negative values at sites located in Marble Canyon to positive values at sites located further downstream in Grand Canyon. Not every eddy aggraded in the same proportion, and there was at least one site in each sediment-transport-flux reach that experienced net erosion (for example, 3L, 55R, 65R, 123L, 214R). Despite widespread deposition of high-elevation sandbars, this pattern was still accompanied by net erosion in some eddies, which also occurred during previous high flows (Andrews and others, 1999; Hazel and others, 1999; Topping and others, 2006a). Because sandbars above reference stage typically occupy a small percentage of total eddy area, large-scale low-elevation erosion, where it occurred, typically resulted in a net loss of sand from eddies and the adjacent 


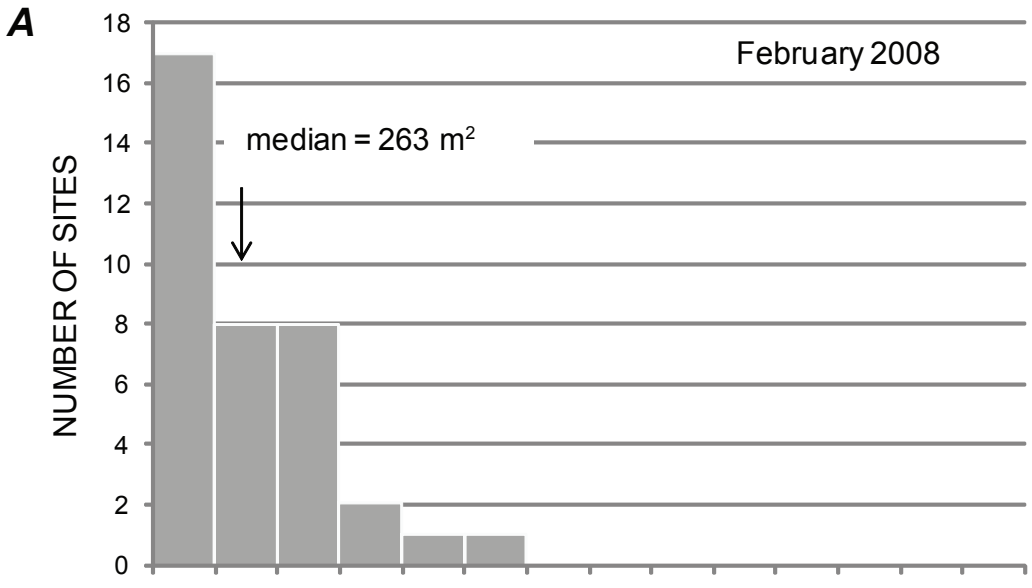

B

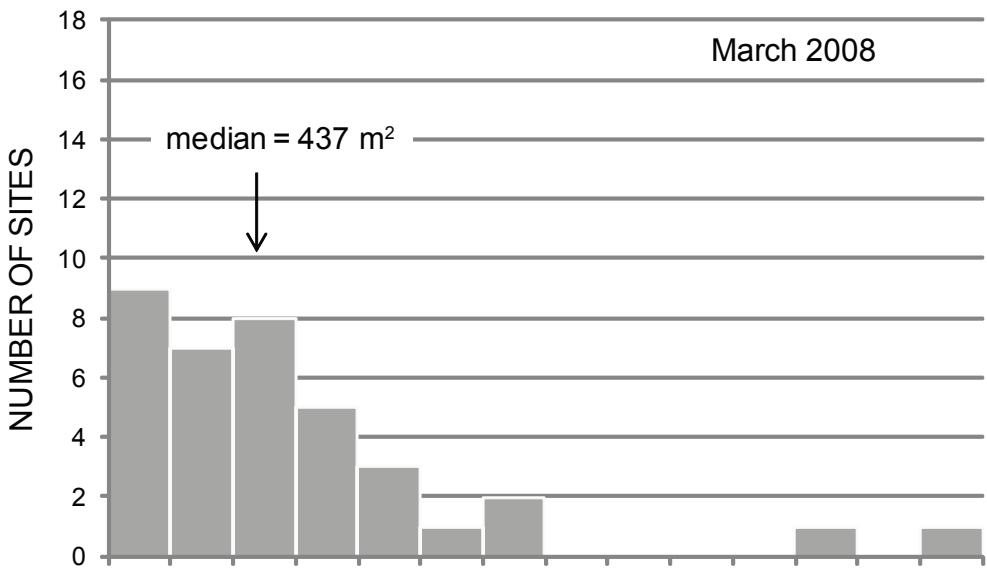

C

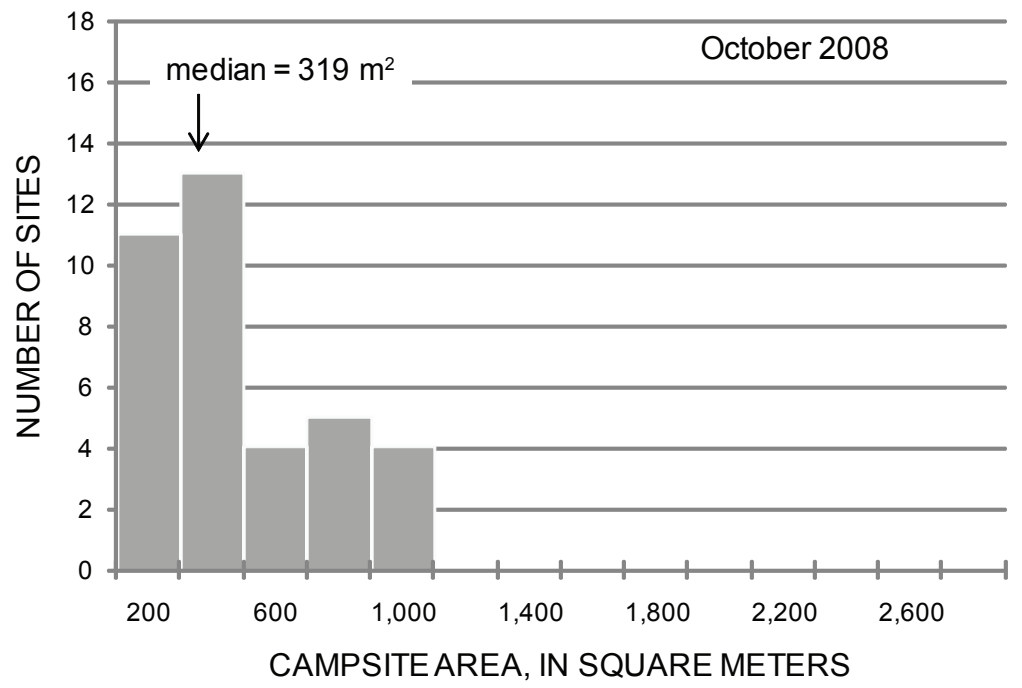

Figure 21. Histograms showing the distribution of campsite area above the reference stage (combined mid- and high-elevation zones shown on figure 2C). A, February 2008. B, April 2008. C, Six months after the $2008 \mathrm{HFE}$. 
A Critical reaches

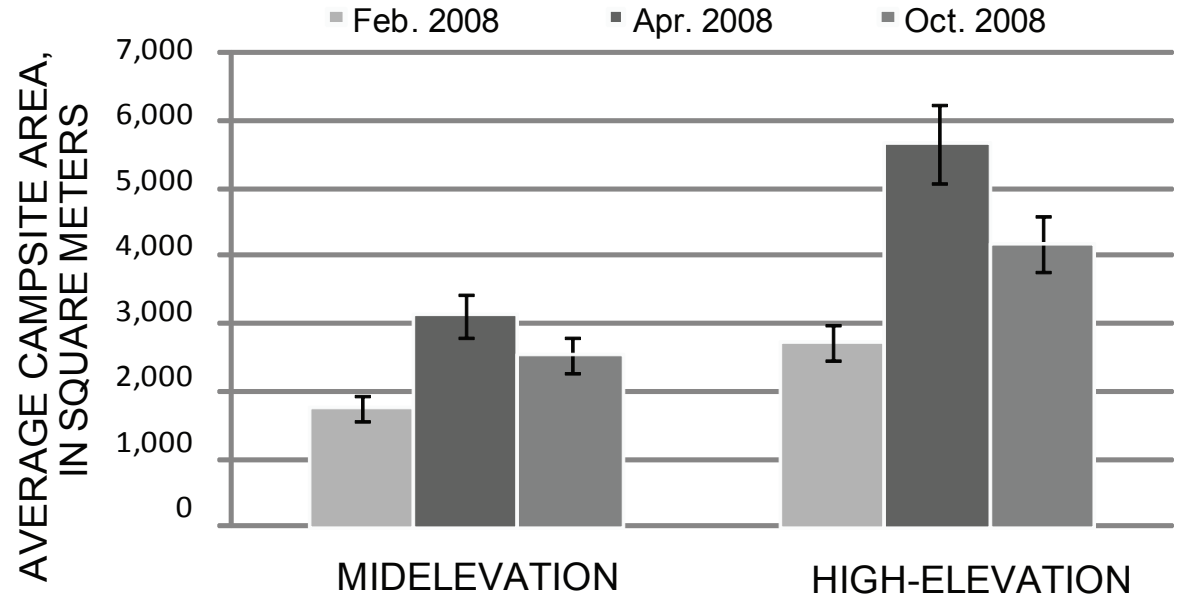

B Noncritical reaches

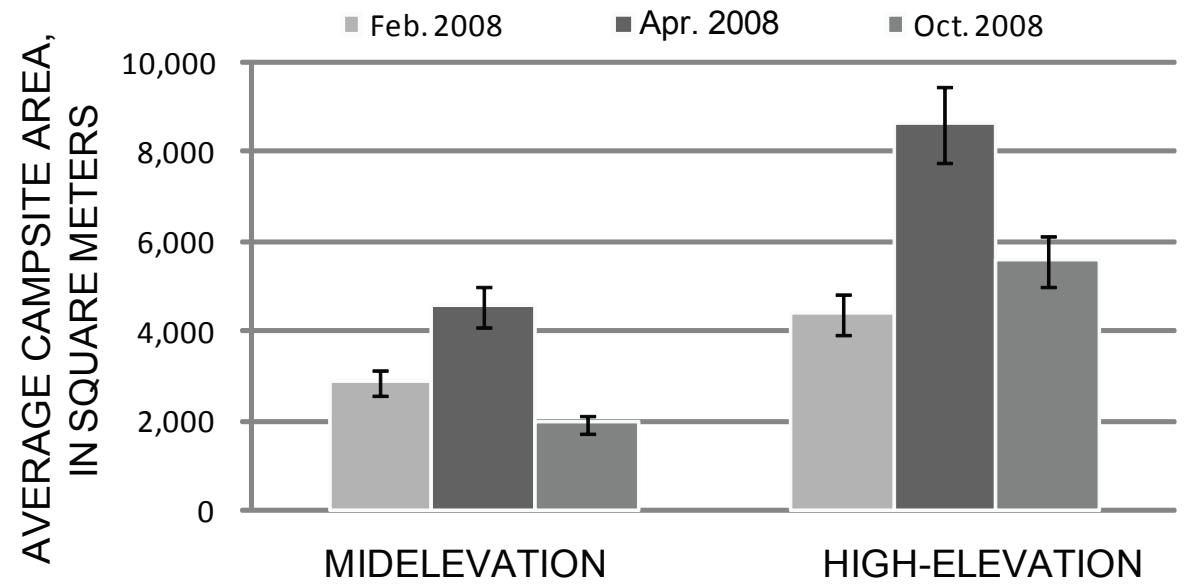

Figure 22. Average campsite area above the reference stage before, after, and about 6 months after the 2008 HFE. Error bars show plus and minus 10 percent of total. $A$, Critical reaches. $B$, Noncritical reaches.

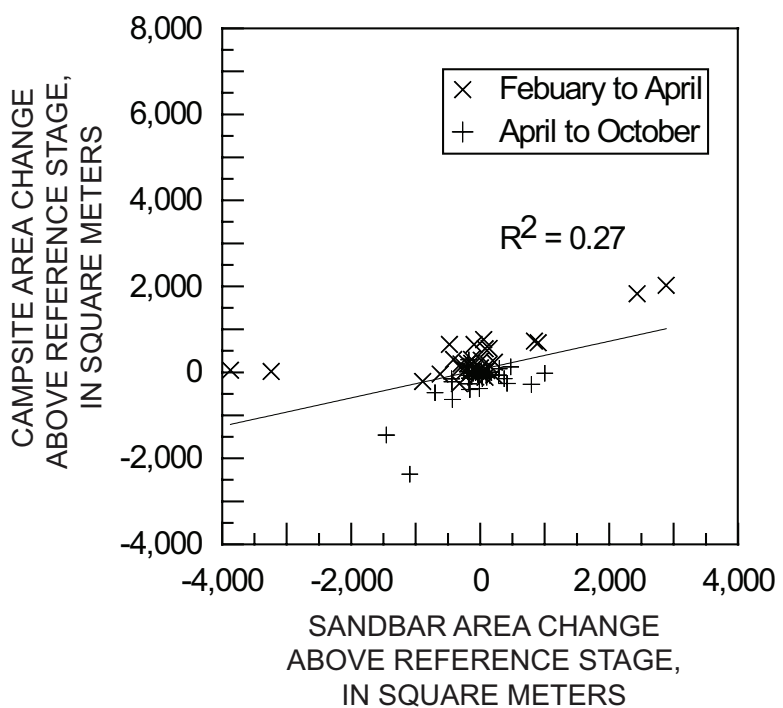

IN SQUARE METERS

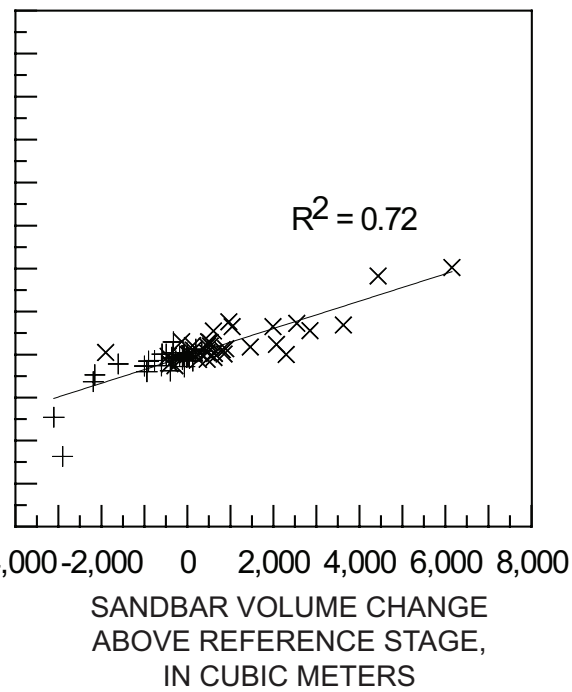

Figure 23. The relation of change in campsite area to change in sandbar area and volume for two time intervals in 2008, pre- to postflood (February-April) and the following 6 months (April-October). A linear regression fit for both time intervals combined is shown. 

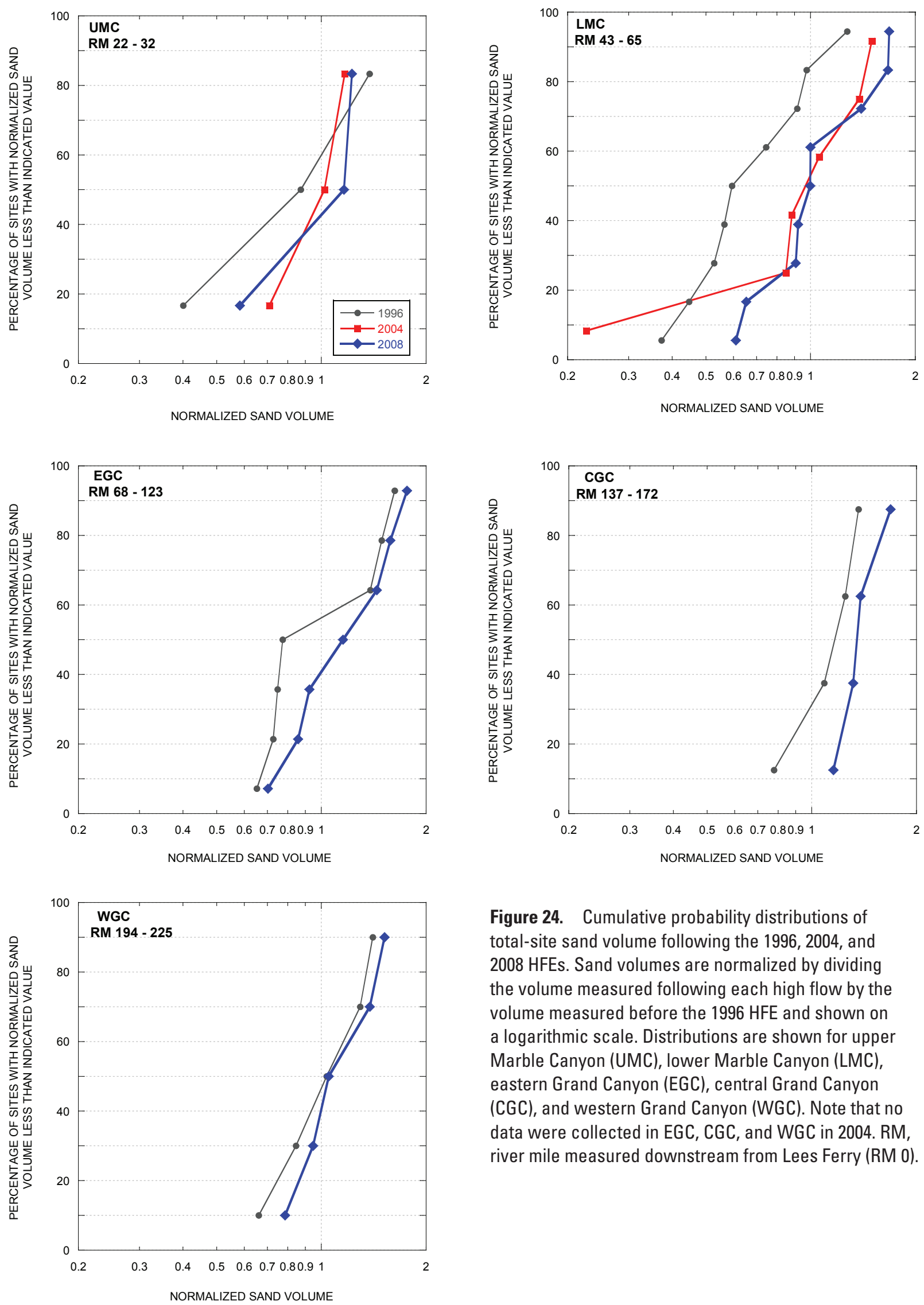

Figure 24. Cumulative probability distributions of total-site sand volume following the 1996, 2004, and 2008 HFEs. Sand volumes are normalized by dividing the volume measured following each high flow by the volume measured before the $1996 \mathrm{HFE}$ and shown on a logarithmic scale. Distributions are shown for upper Marble Canyon (UMC), lower Marble Canyon (LMC), eastern Grand Canyon (EGC), central Grand Canyon (CGC), and western Grand Canyon (WGC). Note that no data were collected in EGC, CGC, and WGC in 2004. RM, river mile measured downstream from Lees Ferry (RM 0 ). 


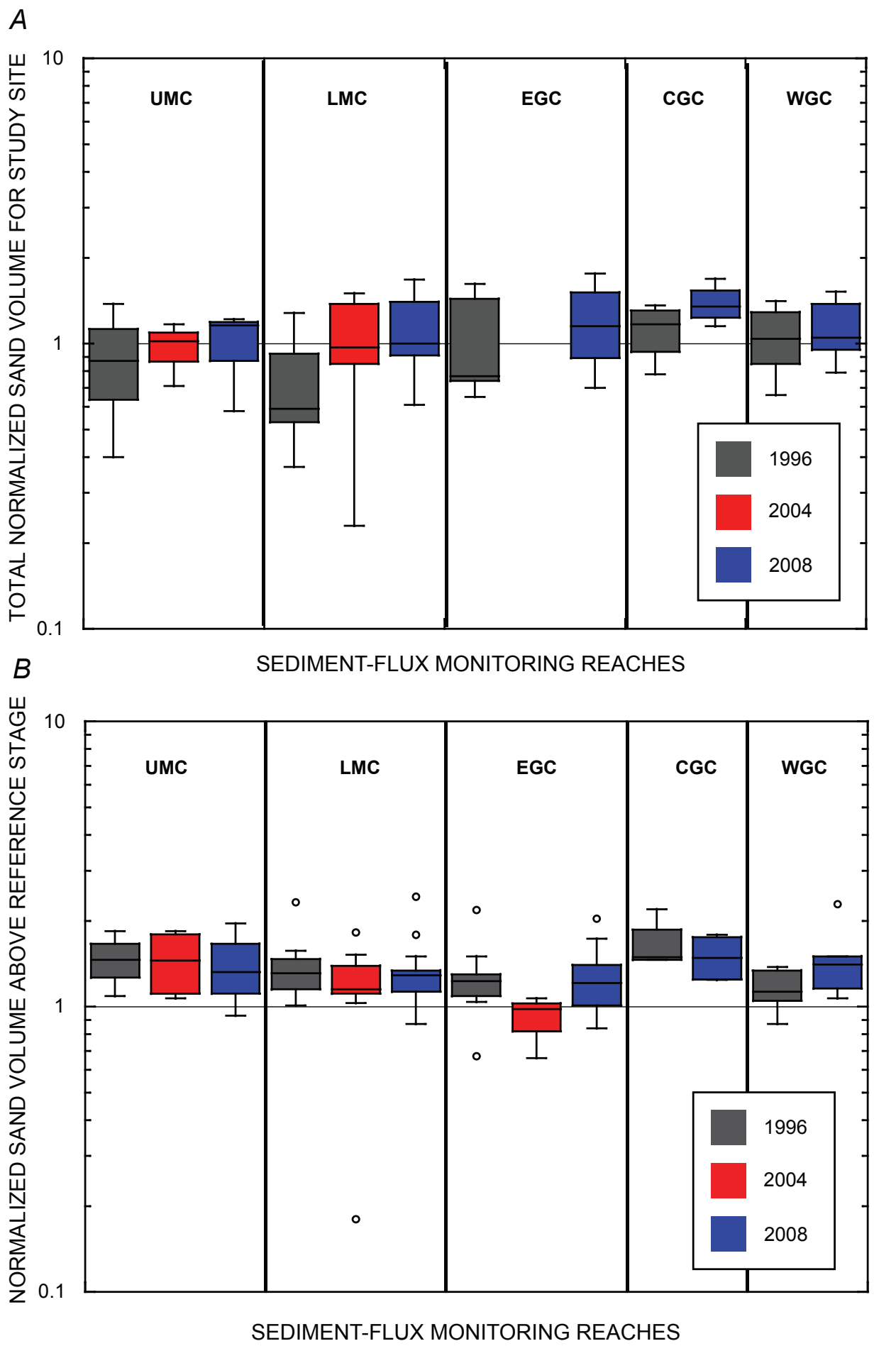

Figure 25. Boxplots showing normalized sand volumes of all sites within each sediment-transport-flux monitoring reach. Sand volumes are normalized by dividing the volume measured following each high flow by the volume measured before the $1996 \mathrm{HFE}$ and shown on a logarithmic scale. Upper Marble Canyon (UMC), lower Marble Canyon (LMC), eastern Grand Canyon (EGC), central Grand Canyon (CGC), and western Grand Canyon (WGC) reaches are shown. $A$, Total-site volume. $B$, Above-reference-stage volume. A boxplot summarizes the distribution of data by showing the interquartile range (25th percentile to 75th percentile) as the height of the box, the median value as the center line within the box, lines drawn to smallest and largest values within one step (equal to 1.5 times the interquartile range) beyond either end of the box, and outliers (values greater than two steps outside the box) as circles. 

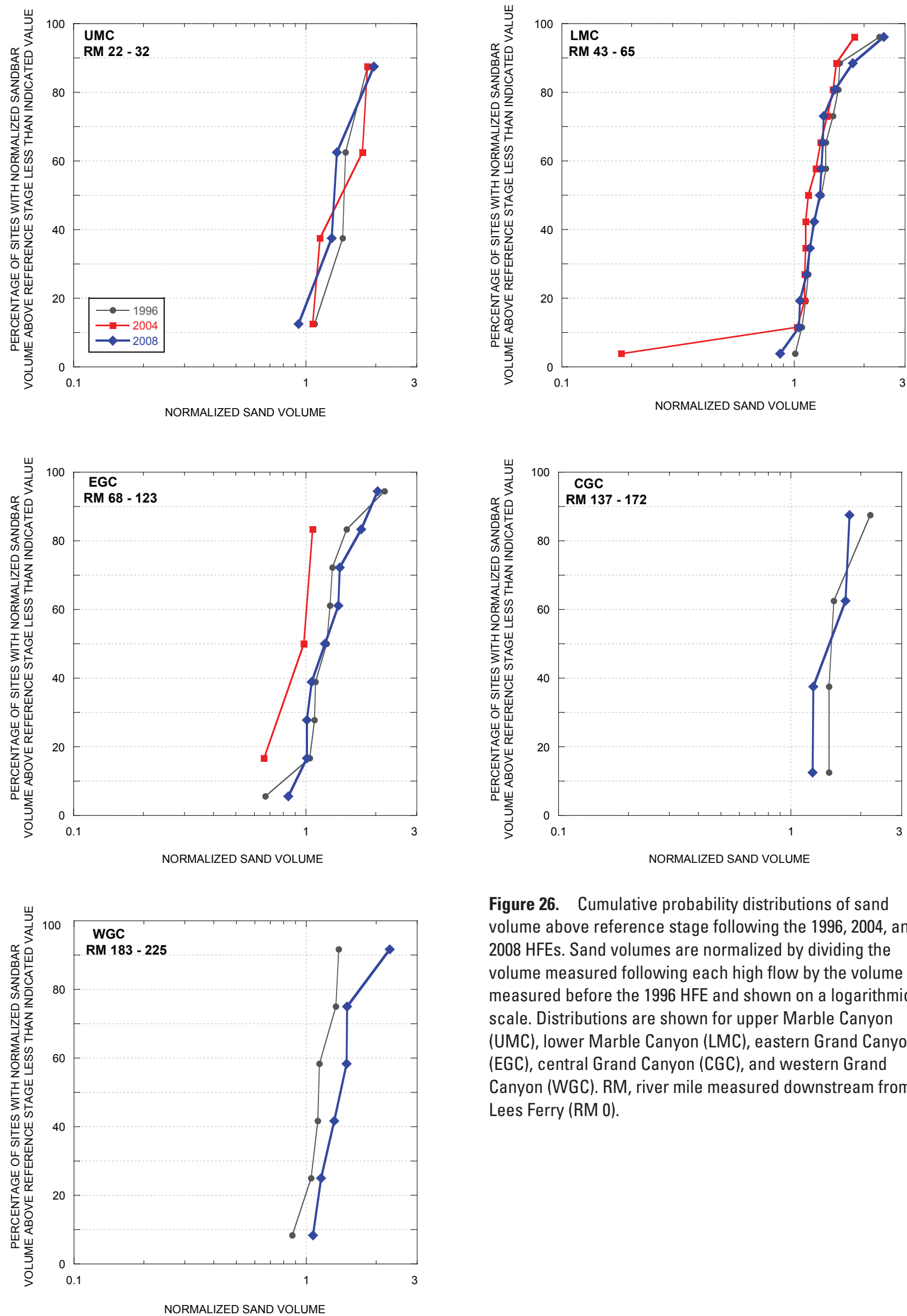

Figure 26. Cumulative probability distributions of sand volume above reference stage following the 1996, 2004, and 2008 HFEs. Sand volumes are normalized by dividing the volume measured following each high flow by the volume measured before the $1996 \mathrm{HFE}$ and shown on a logarithmic scale. Distributions are shown for upper Marble Canyon (UMC), lower Marble Canyon (LMC), eastern Grand Canyon (EGC), central Grand Canyon (CGC), and western Grand Canyon (WGC). RM, river mile measured downstream from Lees Ferry (RM 0). 
channel (fig. 18). These results are similar to those observed in association with the $1996 \mathrm{HFE}$, where the source of sand deposited at the sites differed between sites located in Marble and Grand Canyons (Schmidt, 1999).

Direct comparison of the topographic response of sandbars with those observed during two previous high-flow experiments conducted in 1996 and 2004 indicate that the total-site sand volume was similar or greater following the 2008 HFE in all sediment-transport-flux monitoring reaches. These results suggest that the antecedent condition prior to controlled flooding is an important factor in the resulting sandbar response. During the 2004 high flow, increases in sand volume above reference stage were much greater in $\mathrm{UMC}$ than in LMC and sand volume above reference stage in EGC decreased to a magnitude similar to that measured before the 1996 high flow. In contrast, sand volume above the reference stage following the $2008 \mathrm{HFE}$ was similar to or larger than sand volume for the same sites following the 1996 HFE in all reaches. The greater consistency among the sediment-transport-flux monitoring reaches observed following the $2008 \mathrm{HFE}$ is consistent with the observation that accumulated sand was more evenly distributed throughout all geomorphic reaches preceding the 2008 HFE than it was before the 2004 HFE.

In the 6-month period following the $2008 \mathrm{HFE}$, readjustment of the newly aggraded eddy bars to regular dam operations led to rapid, but declining rates of erosion. Post-2008 HFE sandbar erosion also resulted in concomitant decreases in campsite area. Although newly deposited sandbars may differ in susceptibility to erosion during normal, diurnal fluctuatingflow dam operations associated with the modified low fluctuating flow operation, previous work has shown that elevated fluctuating flows following past sandbar-building experiments result in rapid, systemwide erosion of sandbars of all types (Schmidt and Graf, 1990; Hazel and others, 1999; Rubin and others, 2002). Observations by remote camera indicate that sandbars were stable or gradually eroding between the 2008 HFE and the April 2008 sandbar measurements. Erosion rates were highest between April and May and lower between May and October 2008. The transition in dam operations from spring fluctuating flows to early summer fluctuating flows occurred immediately after the April sandbar measurements, and the remote camera observations show high rates of cutbank retreat at several sites from April to May 2008. These observations suggest that the transition from the spring flows to the higher volume early summer flows caused accelerated sandbar erosion, although the rate of erosion that would have occurred under a different flow regime is not known. Similarly, repeat daily photos of one of the study sites (30R) immediately following the 2004 HFE also demonstrated stability of a rebuilt sandbar until higher and more widely ranging flow fluctuations began in January 2005.
The marked decrease in erosion rates between the early summer flows and the higher, late summer flows is likely owing to the fact that many of the sandbars had substantially eroded by the time the late summer flows started (fig. 20). Previous studies have shown that erosion rates decrease as the availability of erodible sediment decreases (Schmidt and others, 1995; Hazel and others, 1999) or as a stable slope is reached (Budhu and Gobin, 1994). Thus, much of the redistribution of sand had already occurred by the time that the late summer fluctuations occurred, thereby limiting the potential of lower, steady flows released from the dam in September and October 2008 to enhance stability of the 2008 HEF sandbar deposits.

Monitoring and prediction of sandbar response to experimental controlled floods at Glen Canyon Dam are complicated by variations in channel and debris-fan geometry (Schmidt and Graf, 1990), the cumulative downstream nature of the limited sand supply, and the physics that governs sediment transport (Topping and others, 2000; Rubin and Topping, 2001; Topping and others, 2007; Rubin and Topping, 2008), as well as because of the spatial and temporal variability of study sites utilized for monitoring (Schmidt and others, 2004). It is still unclear whether controlled floods will provide a sustainable strategy for longer term habitat restoration and maintenance using only sand supplied by the remaining tributary sources of sand below the dam. This will require integration of the results described in this report with results from other studies and continued experimentation, monitoring, and evaluation.

\section{Acknowledgements}

This study was supported by the U.S. Geological Survey and Bureau of Reclamation through funds provided by the Grand Canyon Monitoring and Research Center. It is offered in tribute to the late Greg Sponenburgh, whose original surveys in 1990 inspired methodologies that remain unchanged today. Permission to work in the study area was granted by Grand Canyon National Park. We thank many people for assistance in collecting field data, including Eric Kellerup, Rod Parnell, Meagan Polino, Nathan Schott, and Emily Thompson. Nathan Schott did most of the bathymetry processing and work leading to topographic comparisons. Keith Kohl is thanked for assisting with various aspects of the study, including data collection and ensuring an accurate geodetic control network for consistent reference of data acquisition. Boat logistics were provided by Humphrey Summit Support. GIS support was provided by James Androwski and Rob Ross. David Topping shared ideas that led to some of the techniques used in this report. We also thank Amy Draut, Helen Fairley, Ted Melis, and Scott Wright for positive discussion and comments that helped clarify and focus this report. Finally, we thank Chris Magirl and two anonymous reviewers for their constructive comments. 


\section{References Cited}

Andrews, E.D., Johnston, C.E., Schmidt, J.C., and Gonzales, M.F., 1999, Topographic evolution of sandbars, in Webb, R.H., Schmidt, J.C., Marzolf, G.R., and Valdez, R.A., eds., The controlled flood in Grand Canyon; scientific experiment and management demonstration: Washington D.C., American Geophysical Union, Geophysical Monograph Series, v. 110, p. 117-130.

Anima, R.J., Marlow, M.S., Rubin, D.M., and Hogg, D.J., 1998, Comparison of sand distribution between April 1994 and June 1996 along six reaches of the Colorado River in Grand Canyon, Arizona: U.S. Geological Survey Open-File Report 98-141, 33 p.

Belknap, B., 2001, Grand Canyon river guide: Evergreen, Colo., Westwater Books, 96 p.

Budhu, M., and Gobin, R., 1994, Instability of sandbars in Grand Canyon: Journal of Hydraulic Engineering, v. 120, no. 8, p. 919-933.

Draut, A.E., and Rubin, D.M., 2008, The role of eolian sediment in the preservation of archeologic sites along the Colorado River in Grand Canyon National Park, Arizona: U.S. Geological Survey Professional Paper 1756, 71 p. [http:// pubs.usgs.gov/pp/1756, last accessed January 17, 2010].

Draut, A.E., Sondossi, H.A., Hazel, J.E., Jr., Andrews, T., Fairley, H.C., Brown, C.R., and Vanaman, K.M., 2009, 2008 weather and aeolian sand-transport data from the Colorado River corridor, Grand Canyon, Arizona: U.S. Geological Survey Open-File Report 2009-1190, 98 p. [http://pubs. usgs.gov/of/2009/1190, last accessed January 17, 2010].

Hazel, J.E., Kaplinski, M., Parnell, R., Manone, M., and Dale, A., 1999, Topographic and bathymetric changes at thirtythree long-term study sites, in Webb, R.H., Schmidt, J.C., Marzolf, G.R., and Valdez, R.A., eds., The controlled flood in Grand Canyon - scientific experiment and management demonstration: Washington, D.C., American Geophysical Union, Geophysical Monograph Series, v. 110, p. 161-183.

Hazel, J.E., Jr., Topping, D.J., Schmidt, J.C., and Kaplinski, M., 2006a, Influence of a dam on fine-sediment storage in a canyon river: Journal of Geophysical Research, v. 111, p. 1-16 [http://www.agu.org/journals/jf/jf0601/2004JF000193/ 2004JF000193.pdf, last accessed January 17, 2010].

Hazel, J.E., Jr., Kaplinski, M., Parnell, R., Kohl, K., and Topping, D.J., 2006b, Stage-discharge relations for the Colorado River in Glen, Marble, and Grand Canyons, Arizona: U.S. Geological Survey Open-File Report 2006-1243, 7 p. [http://pubs.usgs.gov/of/2006/1243, last accessed January 17, 2010].
Hazel, J.E., Kaplinski, M., Parnell, R., Kohl, K., and Schmidt, J.C., 2008, Monitoring fine-grained sediment in the Colorado River ecosystem, Arizona - control network and conventional survey techniques: U.S. Geological Survey Open-File Report 2008-1276, 15 p. [http://pubs.usgs.gov/ of/2008/1276, last accessed January 187, 2010].

Howard, A., and Dolan, R., 1981, Geomorphology of the Colorado River in Grand Canyon: Journal of Geology, v. 89, no. 3, p. 269-297.

Kaplinski, M., Behan, J., Hazel, J.E., Jr., Parnell, R.A., and Fairley, H.C., 2005, Recreational values and campsites in the Colorado River ecosystem, in Gloss, S.P., Lovich, J.E., and Melis, T.S., eds., The State of Colorado River ecosystem in the Grand Canyon: U.S. Geological Survey Circular 1282, p. 193-205.

Kaplinski, M., Hazel, J.E., Jr., Parnell, R., Breedlove, M.J., Kohl, K., and Gonzales, M., 2009, Monitoring fine-sediment volume in the Colorado River ecosystem, Arizonabathymetric survey techniques: U.S. Geological Survey Open-File Report 2009-1207, 33 p.

Kaplinski, M., Hazel, J.E., Jr., and Parnell, R., in press, Colorado River campsite monitoring, 1998-2006, Grand Canyon National Park, Arizona, in Melis, T.S., Hamill, J.F., Coggins, L.C., Jr., Grams, P.E., Kennedy, T.A., Kubly, D.M., and Ralston, B.E., eds., Proceedings of the Colorado River Basin Science and Resource Management Symposium: Scottsdale, Ariz., November 18-20, 2008: U.S. Geological Survey Circular.

Kearsley, L.H., and Warren, K.D., 1993, River campsites in Grand Canyon National Park - inventories and effects of discharge on campsite size and availability, final report: National Park Service, Division of Resources Management, Grand Canyon National Park, submitted to U.S. Bureau of Reclamation, Glen Canyon Environmental Studies, 65 p.

Kearsley, L.H., Schmidt, J.C., and Warren, K.D., 1994, Effects of Glen Canyon Dam on Colorado River sand deposits used as campsites in Grand Canyon National Park, USA: Regulated Rivers, Research and Management, v. 9, no. 3, p. 137-149.

Kieffer, S.W., 1985, The 1983 hydraulic jump in Crystal Rapid - implications for river-running and geomorphic evolution in the Grand Canyon: Journal of Geology, v. 93, no. 4, p. 385-406.

Korman, J., Wiele, S.M., and Torizzo, M., 2004, Modelling effects of discharge on habitat quality and dispersal of juvenile humpback chub (Gila cypha) in the Colorado River, Grand Canyon: River Research and Applications, v. 20, p. 379-400. 
Magirl, C.S., Webb, R.H., and Griffiths, P.G., 2008, Modeling water-surface elevations and virtual shorelines for the Colorado River in Grand Canyon, Arizona: U.S. Geological Survey Scientific Investigations Report 2008-5075, 32 p. [http://pubs.usgs.gov/sir/2008/5075/, last accessed January 17, 2010].

McCullagh, M.J., 1988, Terrain and surface modeling systems; Theory and practice: Photogrammetric Record, v. 12, no. 72, p. 747-779.

Melis, T.S., Webb, R.H., Griffiths, P.G., and Wise, T.W., 1994, Magnitude and frequency data of debris flows in Grand Canyon National Park and vicinity, Arizona: U.S. Geological Survey Water Resources Investigations Report 94-4214, $285 \mathrm{p}$.

National Research Council, 1999, Downstream-adaptive management of Glen Canyon Dam and the Colorado River ecosystem: Washington, D.C., National Academy Press, $230 \mathrm{p}$.

Patten, D.T., Harpman, D.A., Voita, M.I., and Randle, T.J., 2001, A managed flood on the Colorado River-background, objectives, design and implementation: Ecological Applications, v. 11, no. 3, p. 635-643.

Phillips, B.G., Johnson, R.A., Phillips, A.M., III, and Brian, N.J., 1986, Monitoring the effects of recreational use on Colorado River beaches in Grand Canyon National Park: Museum of Northern Arizona Bulletin 55, 131 p.

Rubin, D.M., and Topping, D.J., 2008, Correction to “Quantifying the relative importance of flow regulation and grain-size regulation of suspended-sediment transport $\alpha$, and tracking changes in bed-sediment grain size $\beta$ ": Water Resources Research, v. 44, W09701, 5 p., doi: 10.1029/2008WR006819 [http://www.agu.org/journals/wr/ wr0809/2008WR006819/2008WR006819.pdf, last accessed January 17, 2010].

Rubin, D.M., and Topping, D.J., 2001, Quantifying the relative importance of flow regulation and grain-size regulation of suspended-sediment transport $\alpha$, and tracking changes in bed-sediment grain size $\beta$ : Water Resources Research, v. 37, no. 1, p. 133-146 [http://www.agu.org/journals/wr/v037/ i001/2000WR900250/2000WR900250.pdf, last accessed January 12, 2010].

Rubin, D.M., Schmidt, J.C., and Moore, J.N., 1990, Origin, structure, and evolution of a reattachment bar, Colorado River, Grand Canyon, Arizona: Journal of Sedimentary Petrology, v. 60, no. 6, p. 982-991.

Rubin, D.M., Anima, R.A., and Sanders, R., 1994, Measurements of sand thickness in Grand Canyon, Arizona, and conceptual model for characterizing changes in sandbar volume through time and space: U.S. Geological Survey Open-File Report 94-597, 9 p.
Rubin, D.M., Nelson, J.M., and Topping, D.J., 1998, Relation of inversely graded deposits to suspended-sediment grainsize evolution during the 1996 flood experiment in Grand Canyon: Geology, v. 26, no. 2, p. 99-102.

Rubin, D.M., Topping, D.J., Schmidt, J.C., Hazel, J.E.J., Kaplinski, M., and Melis, T.S., 2002, Recent sediment studies refute Glen Canyon Dam hypothesis: Eos (Transactions, American Geophysical Union), v. 83, no. 25, p. 273, 277-278.

Schmidt, J.C., 1990, Recirculating flow and sedimentation in the Colorado River in Grand Canyon, Arizona: Journal of Geology, v. 98, no. 5, p. 709-724 [http://www.journals. uchicago.edu/doi/abs/10.1086/629435, last accessed December 10, 2009].

Schmidt, J.C., 1999, Summary and synthesis of geomorphic studies conducted during the 1996 controlled flood in Grand Canyon, in Webb, R.H., Schmidt, J.C., Marzolf, G.R., and Valdez, R.A., eds., The controlled flood in Grand Canyon; scientific experiment and management demonstration: Washington, D.C., American Geophysical Union, Geophysical Monograph Series, v. 110, p. 329-341.

Schmidt, J.C., and Graf, J.B., 1990, Aggradation and degradation of alluvial sand deposits, 1965-1986, Colorado River, Grand Canyon National Park, Arizona: U.S. Geological Survey Professional Paper 1493, 74 p.

Schmidt, J.C., and Rubin, D.M., 1995, Regulated stream-flow, fine-grained deposits, and effective discharge in canyons with abundant debris fans, in Costa, J.E., Miller, A.J., Potter, K.W., and Wilcock, P.R., eds., Natural and anthropogenic influences in fluvial geomorphology: Washington D.C., American Geophysical Union, Geophysical Monograph Series, v. 89, p. 177-195.

Schmidt, J.C., Grams, P.E., and Webb, R.H., 1995, Comparison of the magnitude of erosion along two large regulated rivers: Journal of the American Water Resources Association, v. 31, no. 4, p. 617-631.

Schmidt, J.C., Grams, P.E., and Leschin, M.F., 1999, Variation and magnitude of deposition and erosion in three long-term (8-12 km) reaches as determined by photographic analyses, in Webb, R.H., Schmidt, J.C., Marzolf, G.R., and Valdez, R.A., eds., The controlled flood in Grand Canyon; scientific experiment and management demonstration: Washington, D.C., American Geophysical Union, Geophysical Monograph Series, v. 110, p. 185-204.

Schmidt, J.C., Topping, D.J., Grams, P.E., and Hazel, J.E., Jr., 2004, System-wide changes in the distribution of fine sediment in the Colorado River corridor between Glen Canyon Dam and Bright Angel Creek, Arizona, final report: Logan, Utah., Utah State University, submitted to U.S. Geological Survey, Grand Canyon Monitoring and Research Center, cooperative agreement no. 1425-98-FC-40-22640, 107 p. 
Schmidt, J.C., Grams, P.E., and Webb, R.H., 2005, Comparison of the magnitude of erosion along two large regulated rivers: Journal of the American Water Resources Association, v. 31, no. 4, p. 617-631.

Schmidt, J.C., Topping, D.J., Rubin, D.M., Hazel, J.E., Jr., Kaplinski, M., Wiele, S.M., and Goeking, S.A., 2007, Streamflow and sediment data collected to determine the effects of low summer steady flows and habitual maintenance flows in 2000 on the Colorado River between Lees Ferry and Bright Angel Creek, Arizona: U.S. Geological Survey Open-File Report 2007-1268, 79 p.

Stevens, L.E., 1990, The Colorado River in Grand Canyon-a guide: Flagstaff, Ariz., Red Lake Books, 115 p.

Topping, D.J., Rubin, D.M., and Vierra, L.E., Jr., 2000, Colorado River sediment transport pt.1—natural sediment supply limitations and the influence of the Glen Canyon Dam: Water Resources Research, v. 36, no. 2, p. 515-542.

Topping, D.J., Schmidt, J.C., and Vierra, L.E., Jr., 2003, Computation and analysis of the instantaneous-discharge record for the Colorado River at Lees Ferry, Arizona-May 8, 1921, through September 30, 2000: U.S. Geological Survey Professional Paper 1677, 118 p.

Topping, D.J., Rubin, D.M., Schmidt, J.C., Hazel, J.E., Jr., Melis, T.S., Wright, S.A., Kaplinski, M., Draut, A.E., and Breedlove, M.J., 2006a, Comparison of sediment-transport and bar-response results from the 1996 and 2004 controlledflood experiments on the Colorado River in Grand Canyon: [CD-ROM ] Proceedings of the Eighth Federal Interagency Sedimentation Conference, Reno, Nev., April 2-6, 2006, ISBN 0-9779007-1-1.

Topping, D.J., Wright, S.A., Rubin, D.M., and Melis, T.S., 2006b, High-resolution monitoring of suspended-sediment concentration and grain size in the Colorado River using laser diffraction instruments and a three-frequency acoustic system: [CD-ROM ] Proceedings of the Eighth Federal Interagency Sedimentation Conference, Reno, Nev., April 2-6, 2006, ISBN 0-9779007-1-1.

Topping, D.J., Rubin, D.M., and Melis, T.S., 2007, Coupled changes in sand grain size and sand transport drive by changes in the upstream supply of sand in the Colorado River, relative importance of changes in bed-sand grain size and bed-sand area: Sedimentary Geology, v. 202, no. 2, p. 538-561.

Turner, R.M., and Karpiscak, M.M., 1980, Recent vegetation changes along the Colorado River between Glen Canyon Dam and Lake Mead, Arizona: U.S. Geological Survey Professional Paper 1132, 125 p.
U.S. Department of the Interior, 1995, Operation of Glen Canyon Dam final environmental impact statement, Colorado River Storage Project, Coconino County, Arizona: Salt Lake City, Utah, U.S. Bureau of Reclamation, Upper Colorado Regional Office, 337 p.

U.S. Department of the Interior, 2008, Final environmental assessment for experimental releases from Glen Canyon Dam, Arizona, 2008 through 2012: Salt Lake City, Utah, U.S. Bureau of Reclamation, Upper Colorado Region, 68 p. [http://www.usbr.gov/uc/envdocs/ea/gc/2008hfe/index.html, last accessed January 13, 2010].

U.S. Geological Survey, 2006, Colorado mileage system [Spatial database, GIS.BASE_GCMRC_TenthMile] 1st rev. ed.: Grand Canyon Monitoring and Research Center [http://www.gcmrc.gov/products/ims/, last accessed June $16,2006]$.

Webb, R.H., Pringle, P.T., and Rink, G.R., 1989, Debris flows from tributaries of the Colorado River in Grand Canyon National Park, Arizona: U.S. Geological Survey Professional Paper 1492, 39 p.

Webb, R.H., Schmidt, J.C., Marzolf, G.R., and Valdez, R.A., 1999, The controlled flood in Grand Canyon - scientific experiment and management demonstration: Washington, D.C., American Geophysical Union, Geophysical Monograph Series, v. 110, $367 \mathrm{p}$.

Wiele, S.M., and Torizzo, M., 2005, Modeling of sand deposition in archeologically significant reaches of the Colorado River in Grand Canyon, USA, in Bates, P.D., Lane, S.N., and Ferguson, R.I., eds., Computational fluid dynamics: applications in environmental hydraulics: Hoboken, N.J., Wiley, p. 357-394.

Wiele, S.M., Garf, J.B., and Smith, J.D., 1996, Sand deposition in the Colorado River in the Grand Canyon from flooding of the Little Colorado River: Water Resources Research, v. 32 , no. 12 , p. $3579-3596$.

Wilson, R.P., 1986, Sonar patterns of the Colorado riverbed, Grand Canyon, in Fourth Federal Interagency Sedimentation Conference, Las Vegas, Nev., March 24-27, 1986, Proceedings, v. 2, p. 5-133, 135-142.

Wright, S.A., Melis, T.S., Topping, D.J., and Rubin, D.M., 2005, Influence of Glen Canyon Dam operations on downstream sand resources of the Colorado River in Grand Canyon, in Gloss, S.P., Lovich, J.E., and Melis, T.S. eds., The state of the Colorado River ecosystem in Grand Canyon: U.S. Geological Survey Circular 1282, p. 17-31. 
Appendixes A-B 


\section{Appendix A. Summary of study sites and types of data collected, Colorado River in Marble and Grand Canyons}

[Site ID is river mile (RM) location based on the RM centerline (U.S. Geological Survey, 2006) downstream from Lees Ferry (river mile 0) in Grand Canyon National Park. The descriptors "L" and "R" denote the location of the emergent sandbar on left and right sides of the river, respectively, facing downstream. Date of study is that of topographic survey (month/day/year). Discharges were estimated from the water surface during topographic surveys using the stage-discharge relations of Hazel and others (2006b). V, data were collected. -, no data were collected or data were not recoverable.]

\begin{tabular}{|c|c|c|c|c|c|c|c|}
\hline $\begin{array}{l}\text { Site } \\
\text { ID }\end{array}$ & Date & $\begin{array}{l}\text { Discharge } \\
\left(\mathrm{m}^{3} / \mathrm{s}\right)\end{array}$ & $\begin{array}{c}\text { Topographic } \\
\text { survey }\end{array}$ & $\begin{array}{c}\text { Bathymetric } \\
\text { survey }\end{array}$ & $\begin{array}{c}\text { Campsite } \\
\text { survey }\end{array}$ & $\begin{array}{l}\text { Time-lapse } \\
\text { photography }\end{array}$ & $\begin{array}{l}\text { Scour } \\
\text { chains }\end{array}$ \\
\hline \multirow{4}{*}{$1 \mathrm{R}$} & 02/02/08 & 285 & $\sqrt{ }$ & - & - & - & - \\
\hline & $03 / 28 / 08$ & 278 & $\sqrt{ }$ & $\sqrt{ }$ & - & - & - \\
\hline & $05 / 17 / 08$ & 232 & $\sqrt{ }$ & - & - & - & - \\
\hline & $10 / 11 / 08$ & 355 & $\sqrt{ }$ & - & - & - & - \\
\hline \multirow{4}{*}{$3 \mathrm{~L}$} & $02 / 02 / 08$ & 322 & $\sqrt{ }$ & $\sqrt{ }$ & - & $\sqrt{ }$ & - \\
\hline & $03 / 28 / 08$ & 352 & $\sqrt{ }$ & $\sqrt{ }$ & - & $\sqrt{ }$ & - \\
\hline & $05 / 17 / 08$ & 318 & $\sqrt{ }$ & - & - & $\sqrt{ }$ & - \\
\hline & $10 / 11 / 08$ & 394 & $\sqrt{ }$ & - & - & $\sqrt{ }$ & - \\
\hline \multirow{3}{*}{$8 \mathrm{~L}$} & 02/02/08 & 253 & $\sqrt{ }$ & - & $\sqrt{ }$ & - & - \\
\hline & $03 / 28 / 08$ & 313 & $\sqrt{ }$ & - & $\sqrt{ }$ & $\sqrt{ }$ & - \\
\hline & $10 / 11 / 08$ & 360 & $\sqrt{ }$ & - & $\sqrt{ }$ & $\sqrt{ }$ & - \\
\hline \multirow{4}{*}{$9 \mathrm{~L}$} & 02/03/08 & 252 & $\sqrt{ }$ & - & - & - & - \\
\hline & $03 / 29 / 08$ & 300 & $\sqrt{ }$ & $\sqrt{ }$ & - & - & - \\
\hline & $05 / 17 / 08$ & 369 & $\sqrt{ }$ & - & - & - & - \\
\hline & $10 / 12 / 08$ & 358 & $\sqrt{ }$ & - & - & - & - \\
\hline \multirow{3}{*}{$16 \mathrm{~L}$} & 02/03/08 & 282 & $\sqrt{ }$ & $\sqrt{ }$ & $\sqrt{ }$ & - & - \\
\hline & 03/29/08 & 279 & $\sqrt{ }$ & $\sqrt{ }$ & $\sqrt{ }$ & $\sqrt{ }$ & - \\
\hline & $10 / 12 / 08$ & 384 & $\sqrt{ }$ & - & $\sqrt{ }$ & $?$ & - \\
\hline \multirow{4}{*}{$22 \mathrm{R}$} & 02/03/08 & 284 & $\sqrt{ }$ & $\sqrt{ }$ & $\sqrt{ }$ & $\sqrt{ }$ & - \\
\hline & 03/29/08 & 267 & $\sqrt{ }$ & $\sqrt{ }$ & $\sqrt{ }$ & $\sqrt{ }$ & - \\
\hline & $05 / 17 / 08$ & 265 & $\sqrt{ }$ & - & - & $\sqrt{ }$ & - \\
\hline & $10 / 12 / 08$ & 366 & $\sqrt{ }$ & - & $\sqrt{ }$ & $\sqrt{ }$ & - \\
\hline \multirow{3}{*}{$24 \mathrm{~L}$} & 02/04/08 & 255 & $\sqrt{ }$ & - & $\sqrt{ }$ & - & - \\
\hline & 03/29/08 & 257 & $\sqrt{ }$ & - & $\sqrt{ }$ & - & - \\
\hline & $10 / 12 / 08$ & 368 & $\sqrt{ }$ & - & $\sqrt{ }$ & - & - \\
\hline \multirow{3}{*}{$29 \mathrm{~L}$} & 02/04/08 & 287 & $\sqrt{ }$ & - & $\sqrt{ }$ & - & - \\
\hline & $03 / 30 / 08$ & 246 & $\sqrt{ }$ & - & $\sqrt{ }$ & - & - \\
\hline & $09 / 22 / 08$ & 309 & V & - & $\sqrt{ }$ & - & - \\
\hline \multirow{4}{*}{$30 \mathrm{R}$} & 02/04/08 & 266 & $\sqrt{ }$ & $\sqrt{ }$ & $\sqrt{ }$ & $\sqrt{ }$ & $\sqrt{ }$ \\
\hline & 03/30/08 & 257 & $\sqrt{ }$ & $\sqrt{ }$ & $\sqrt{ }$ & $\sqrt{ }$ & - \\
\hline & 05/19/08 & 336 & $\sqrt{ }$ & - & - & $\sqrt{ }$ & - \\
\hline & $10 / 13 / 08$ & 365 & $\sqrt{ }$ & - & $\sqrt{ }$ & $\sqrt{ }$ & - \\
\hline \multirow{3}{*}{$32 \mathrm{R}$} & $02 / 05 / 08$ & 265 & $\sqrt{ }$ & $\sqrt{ }$ & $\sqrt{ }$ & - & - \\
\hline & $03 / 30 / 08$ & 235 & $\sqrt{ }$ & $\sqrt{ }$ & $\sqrt{ }$ & - & - \\
\hline & $10 / 13 / 08$ & 379 & $\sqrt{ }$ & - & - & - & - \\
\hline \multirow{3}{*}{$33 \mathrm{~L}$} & 02/05/08 & 264 & $\sqrt{ }$ & - & - & - & - \\
\hline & 03/30/08 & 220 & $\sqrt{ }$ & $\sqrt{ }$ & - & - & - \\
\hline & 10/13/08 & 347 & $\sqrt{ }$ & - & - & - & - \\
\hline \multirow{3}{*}{$35 \mathrm{~L}$} & 02/05/08 & 272 & $\sqrt{ }$ & $\sqrt{ }$ & $\sqrt{ }$ & - & - \\
\hline & 03/30/08 & 212 & $\sqrt{ }$ & $\sqrt{ }$ & $\sqrt{ }$ & - & - \\
\hline & $10 / 13 / 08$ & 348 & $\sqrt{ }$ & $\sqrt{ }$ & $\sqrt{ }$ & - & - \\
\hline
\end{tabular}


Appendix A. Summary of study sites and types of data collected, Colorado River in Marble and Grand Canyons. - Continued

[Site ID is river mile (RM) location based on the RM centerline (U.S. Geological Survey, 2006) downstream from Lees Ferry (river mile 0) in Grand Canyon National Park. The descriptors "L" and "R" denote the location of the emergent sandbar on left and right sides of the river, respectively, facing downstream. Date of study is that of topographic survey (month/day/year). Discharges were estimated from the water surface during topographic surveys using the stage-discharge relations of Hazel and others (2006b). V, data were collected. -, no data were collected or data were not recoverable.]

\begin{tabular}{|c|c|c|c|c|c|c|c|}
\hline $\begin{array}{l}\text { Site } \\
\text { ID }\end{array}$ & Date & $\begin{array}{l}\text { Discharge } \\
\left(\mathrm{m}^{3} / \mathrm{s}\right)\end{array}$ & $\begin{array}{c}\text { Topographic } \\
\text { survey }\end{array}$ & $\begin{array}{c}\text { Bathymetric } \\
\text { survey }\end{array}$ & $\begin{array}{c}\text { Campsite } \\
\text { survey }\end{array}$ & $\begin{array}{l}\text { Time-lapse } \\
\text { photography }\end{array}$ & $\begin{array}{l}\text { Scour } \\
\text { chains }\end{array}$ \\
\hline $41 R$ & $\begin{array}{l}02 / 05 / 08 \\
03 / 31 / 08 \\
05 / 19 / 08 \\
10 / 14 / 08\end{array}$ & $\begin{array}{l}303 \\
316 \\
294 \\
357\end{array}$ & $\begin{array}{l}\sqrt{ } \\
\sqrt{ } \\
\sqrt{ } \\
\sqrt{ }\end{array}$ & $\begin{array}{l}\sqrt{ } \\
\sqrt{ } \\
- \\
-\end{array}$ & $\begin{array}{l}\sqrt{ } \\
\sqrt{ } \\
- \\
\sqrt{ }\end{array}$ & $\begin{array}{l}\sqrt{ } \\
- \\
\sqrt{ } \\
\sqrt{ }\end{array}$ & $\begin{array}{l}- \\
- \\
-\end{array}$ \\
\hline $43 \mathrm{~L}$ & $\begin{array}{l}02 / 06 / 08 \\
03 / 31 / 08 \\
05 / 19 / 08 \\
10 / 14 / 08\end{array}$ & $\begin{array}{l}282 \\
273 \\
301 \\
368\end{array}$ & $\begin{array}{l}\sqrt{ } \\
\sqrt{ } \\
\sqrt{ } \\
\sqrt{ }\end{array}$ & $\begin{array}{l}\sqrt{ } \\
\sqrt{ } \\
- \\
-\end{array}$ & $\begin{array}{l}\sqrt{ } \\
\sqrt{ } \\
- \\
\sqrt{ }\end{array}$ & $\begin{array}{l}- \\
- \\
-\end{array}$ & $\begin{array}{l}- \\
- \\
-\end{array}$ \\
\hline $44 \mathrm{~L}$ & $\begin{array}{l}02 / 06 / 08 \\
03 / 31 / 08 \\
05 / 19 / 08 \\
10 / 14 / 08\end{array}$ & $\begin{array}{l}270 \\
237 \\
- \\
345\end{array}$ & $\begin{array}{l}\sqrt{ } \\
\sqrt{ } \\
- \\
\sqrt{ }\end{array}$ & $\begin{array}{l}\sqrt{ } \\
\sqrt{ } \\
- \\
-\end{array}$ & $\begin{array}{l}\sqrt{ } \\
\sqrt{ } \\
- \\
\sqrt{ }\end{array}$ & $\begin{array}{l}\sqrt{ } \\
\sqrt{ } \\
\sqrt{ } \\
\sqrt{ }\end{array}$ & $\begin{array}{l}\sqrt{ } \\
- \\
- \\
-\end{array}$ \\
\hline $45 \mathrm{~L}$ & $\begin{array}{l}02 / 07 / 08 \\
03 / 31 / 08 \\
05 / 20 / 08 \\
10 / 15 / 08\end{array}$ & $\begin{array}{l}320 \\
227 \\
385 \\
358\end{array}$ & $\begin{array}{l}\sqrt{ } \\
\sqrt{ } \\
\sqrt{ } \\
\sqrt{ }\end{array}$ & $\begin{array}{l}\sqrt{ } \\
\sqrt{ } \\
- \\
-\end{array}$ & $\begin{array}{l}\sqrt{ } \\
\sqrt{ } \\
- \\
\sqrt{ }\end{array}$ & $\begin{array}{l}\sqrt{ } \\
\sqrt{ } \\
\sqrt{ } \\
\sqrt{ }\end{array}$ & $\begin{array}{l}- \\
- \\
- \\
-\end{array}$ \\
\hline $47 R$ & $\begin{array}{l}02 / 07 / 08 \\
03 / 31 / 08 \\
05 / 20 / 08 \\
10 / 15 / 08\end{array}$ & $\begin{array}{l}339 \\
307 \\
343 \\
361\end{array}$ & $\begin{array}{l}\sqrt{ } \\
\sqrt{ } \\
\sqrt{ } \\
\sqrt{ }\end{array}$ & $\begin{array}{l}- \\
- \\
\sqrt{ } \\
\sqrt{ }\end{array}$ & $\begin{array}{l}\sqrt{ } \\
\sqrt{ } \\
- \\
\sqrt{ }\end{array}$ & $\begin{array}{l}\sqrt{ } \\
\sqrt{ } \\
\sqrt{ } \\
\sqrt{ }\end{array}$ & $\begin{array}{l}- \\
- \\
- \\
-\end{array}$ \\
\hline $49 R$ & $\begin{array}{l}02 / 07 / 08 \\
03 / 31 / 08 \\
05 / 20 / 08 \\
09 / 24 / 08\end{array}$ & $\begin{array}{l}253 \\
282 \\
394 \\
346\end{array}$ & $\begin{array}{l}\sqrt{ } \\
\sqrt{ } \\
\sqrt{ } \\
\sqrt{ }\end{array}$ & $\begin{array}{l}\sqrt{ } \\
\sqrt{ } \\
- \\
-\end{array}$ & $\begin{array}{l}- \\
- \\
- \\
-\end{array}$ & $\begin{array}{l}- \\
- \\
-\end{array}$ & $\begin{array}{l}- \\
- \\
- \\
-\end{array}$ \\
\hline $49 \mathrm{~L}$ & $\begin{array}{l}02 / 07 / 08 \\
04 / 01 / 08 \\
05 / 20 / 08 \\
09 / 24 / 08\end{array}$ & $\begin{array}{l}253 \\
256 \\
343 \\
358\end{array}$ & $\begin{array}{l}\sqrt{ } \\
\sqrt{ } \\
\sqrt{ } \\
\sqrt{ }\end{array}$ & $\begin{array}{l}\sqrt{ } \\
\sqrt{ } \\
- \\
-\end{array}$ & $\begin{array}{l}- \\
- \\
-\end{array}$ & $\begin{array}{l}- \\
- \\
-\end{array}$ & $\begin{array}{l}- \\
- \\
- \\
-\end{array}$ \\
\hline $50 \mathrm{R}$ & $\begin{array}{l}04 / 01 / 08 \\
05 / 20 / 08 \\
10 / 15 / 08\end{array}$ & $\begin{array}{l}292 \\
309 \\
360\end{array}$ & $\begin{array}{l}\sqrt{ } \\
\sqrt{ } \\
\sqrt{ }\end{array}$ & $\begin{array}{l}\sqrt{ } \\
- \\
-\end{array}$ & $\begin{array}{l}\sqrt{ } \\
- \\
\sqrt{ }\end{array}$ & $\begin{array}{l}\sqrt{ } \\
\sqrt{ } \\
\sqrt{ }\end{array}$ & - \\
\hline $51 \mathrm{~L}$ & $\begin{array}{l}02 / 08 / 08 \\
04 / 02 / 08 \\
05 / 21 / 08 \\
10 / 15 / 08\end{array}$ & $\begin{array}{l}335 \\
328 \\
414 \\
358\end{array}$ & $\begin{array}{l}\sqrt{ } \\
\sqrt{ } \\
\sqrt{ } \\
\sqrt{ }\end{array}$ & $\begin{array}{l}\sqrt{ } \\
\sqrt{ } \\
- \\
-\end{array}$ & $\begin{array}{l}\sqrt{ } \\
\sqrt{ } \\
- \\
\sqrt{ }\end{array}$ & $\begin{array}{l}- \\
- \\
- \\
-\end{array}$ & $\begin{array}{l}- \\
- \\
- \\
-\end{array}$ \\
\hline $54 \mathrm{R}$ & $\begin{array}{l}02 / 08 / 08 \\
04 / 02 / 08 \\
10 / 16 / 08\end{array}$ & $\begin{array}{l}334 \\
319 \\
358\end{array}$ & $\begin{array}{l}\sqrt{ } \\
\sqrt{ } \\
\sqrt{ }\end{array}$ & $\begin{array}{l}\sqrt{ } \\
\sqrt{ } \\
-\end{array}$ & $\begin{array}{l}- \\
- \\
-\end{array}$ & $\begin{array}{l}- \\
- \\
-\end{array}$ & $\begin{array}{l}\sqrt{ } \\
- \\
-\end{array}$ \\
\hline
\end{tabular}


Appendix A. Summary of study sites and types of data collected, Colorado River in Marble and Grand Canyons. — Continued

[Site ID is river mile (RM) location based on the RM centerline (U.S. Geological Survey, 2006) downstream from Lees Ferry (river mile 0) in Grand Canyon National Park. The descriptors "L" and "R" denote the location of the emergent sandbar on left and right sides of the river, respectively, facing downstream. Date of study is that of topographic survey (month/day/year). Discharges were estimated from the water surface during topographic surveys using the stage-discharge relations of Hazel and others (2006b). V, data were collected. -, no data were collected or data were not recoverable.]

\begin{tabular}{|c|c|c|c|c|c|c|c|}
\hline $\begin{array}{l}\text { Site } \\
\text { ID }\end{array}$ & Date & $\begin{array}{c}\text { Discharge } \\
\left(\mathrm{m}^{3} / \mathrm{s}\right)\end{array}$ & $\begin{array}{c}\text { Topographic } \\
\text { survey }\end{array}$ & $\begin{array}{c}\text { Bathymetric } \\
\text { survey }\end{array}$ & $\begin{array}{c}\text { Campsite } \\
\text { survey }\end{array}$ & $\begin{array}{c}\text { Time-lapse } \\
\text { photography }\end{array}$ & $\begin{array}{l}\text { Scour } \\
\text { chains }\end{array}$ \\
\hline $55 R$ & $\begin{array}{l}02 / 08 / 08 \\
04 / 02 / 08 \\
05 / 21 / 08 \\
10 / 16 / 08\end{array}$ & $\begin{array}{l}318 \\
275 \\
328 \\
348\end{array}$ & $\begin{array}{l}\sqrt{ } \\
\sqrt{ } \\
\sqrt{ } \\
\sqrt{ }\end{array}$ & $\begin{array}{l}\sqrt{ } \\
\sqrt{ } \\
- \\
-\end{array}$ & $\begin{array}{l}- \\
\sqrt{ } \\
- \\
-\end{array}$ & $\begin{array}{l}\sqrt{ } \\
\sqrt{ } \\
\sqrt{ } \\
\sqrt{ }\end{array}$ & $\begin{array}{l}- \\
- \\
-\end{array}$ \\
\hline $56 \mathrm{R}$ & $\begin{array}{l}04 / 02 / 08 \\
05 / 21 / 08 \\
10 / 16 / 08\end{array}$ & $\begin{array}{l}252 \\
303 \\
372\end{array}$ & $\begin{array}{l}\sqrt{ } \\
\sqrt{ } \\
\sqrt{ }\end{array}$ & - & $\begin{array}{l}- \\
-\end{array}$ & $\begin{array}{l}- \\
-\end{array}$ & $\begin{array}{l}- \\
-\end{array}$ \\
\hline $58 \mathrm{~L}$ & $\begin{array}{l}02 / 08 / 08 \\
04 / 03 / 08 \\
05 / 23 / 08 \\
10 / 16 / 08\end{array}$ & $\begin{array}{l}307 \\
337 \\
- \\
368\end{array}$ & $\begin{array}{l}\sqrt{ } \\
\sqrt{ } \\
\sqrt{ } \\
\sqrt{ }\end{array}$ & $\begin{array}{l}- \\
- \\
-\end{array}$ & $\begin{array}{l}- \\
- \\
-\end{array}$ & $\begin{array}{l}\sqrt{ } \\
\sqrt{ } \\
\sqrt{ } \\
\sqrt{ }\end{array}$ & $\begin{array}{l}- \\
- \\
-\end{array}$ \\
\hline $62 R$ & $\begin{array}{l}02 / 09 / 08 \\
04 / 03 / 08 \\
10 / 17 / 08\end{array}$ & $\begin{array}{l}352 \\
380 \\
356\end{array}$ & $\begin{array}{l}\sqrt{ } \\
\sqrt{ } \\
\sqrt{ }\end{array}$ & $\begin{array}{l}\sqrt{ } \\
\sqrt{ } \\
-\end{array}$ & $\begin{array}{l}\sqrt{ } \\
\sqrt{ } \\
\sqrt{ }\end{array}$ & $\begin{array}{l}- \\
- \\
-\end{array}$ & $\begin{array}{l}- \\
-\end{array}$ \\
\hline $63 \mathrm{~L}$ & $\begin{array}{l}02 / 09 / 08 \\
04 / 03 / 08 \\
05 / 24 / 08 \\
10 / 17 / 08\end{array}$ & $\begin{array}{l}337 \\
340 \\
397 \\
340\end{array}$ & $\begin{array}{l}\sqrt{ } \\
\sqrt{ } \\
\sqrt{ } \\
\sqrt{ }\end{array}$ & $\begin{array}{l}\sqrt{ } \\
\sqrt{ } \\
- \\
-\end{array}$ & $\begin{array}{l}- \\
- \\
-\end{array}$ & $\begin{array}{l}- \\
- \\
-\end{array}$ & $\begin{array}{l}- \\
- \\
-\end{array}$ \\
\hline $65 R$ & $\begin{array}{l}02 / 09 / 08 \\
04 / 03 / 08 \\
05 / 24 / 08 \\
10 / 17 / 08\end{array}$ & $\begin{array}{l}372 \\
332 \\
410 \\
387\end{array}$ & $\begin{array}{l}\sqrt{ } \\
\sqrt{ } \\
\sqrt{ } \\
\sqrt{ }\end{array}$ & $\begin{array}{l}\sqrt{ } \\
\sqrt{ } \\
- \\
-\end{array}$ & $\begin{array}{l}- \\
- \\
-\end{array}$ & $\begin{array}{l}- \\
- \\
-\end{array}$ & $\begin{array}{l}- \\
- \\
-\end{array}$ \\
\hline $65 \mathrm{~L}$ & $\begin{array}{l}02 / 09 / 08 \\
04 / 04 / 08 \\
05 / 24 / 08 \\
10 / 17 / 08\end{array}$ & $\begin{array}{l}375 \\
347 \\
424 \\
368\end{array}$ & $\begin{array}{l}\sqrt{ } \\
\sqrt{ } \\
\sqrt{ } \\
\sqrt{ }\end{array}$ & $\begin{array}{l}\sqrt{ } \\
\sqrt{ } \\
- \\
-\end{array}$ & $\begin{array}{l}- \\
- \\
- \\
-\end{array}$ & $\begin{array}{l}\sqrt{ } \\
\sqrt{ } \\
\sqrt{ } \\
\sqrt{ }\end{array}$ & $\begin{array}{l}- \\
- \\
-\end{array}$ \\
\hline $66 \mathrm{~L}$ & $\begin{array}{l}02 / 10 / 08 \\
04 / 04 / 08 \\
05 / 24 / 08 \\
10 / 18 / 08\end{array}$ & $\begin{array}{l}265 \\
315 \\
353 \\
363\end{array}$ & $\begin{array}{l}\sqrt{ } \\
\sqrt{ } \\
\sqrt{ } \\
\sqrt{ }\end{array}$ & $\begin{array}{l}- \\
- \\
-\end{array}$ & $\begin{array}{l}- \\
- \\
- \\
-\end{array}$ & $\begin{array}{l}\sqrt{ } \\
\sqrt{ } \\
\sqrt{ } \\
\sqrt{ }\end{array}$ & $\begin{array}{l}- \\
- \\
-\end{array}$ \\
\hline $68 \mathrm{R}$ & $\begin{array}{l}02 / 10 / 08 \\
04 / 05 / 08 \\
05 / 25 / 08 \\
10 / 18 / 08\end{array}$ & $\begin{array}{l}279 \\
341 \\
420 \\
344\end{array}$ & $\begin{array}{l}\sqrt{ } \\
\sqrt{ } \\
\sqrt{ } \\
\sqrt{ }\end{array}$ & $\begin{array}{l}\sqrt{ } \\
\sqrt{ } \\
- \\
-\end{array}$ & $\begin{array}{l}- \\
- \\
-\end{array}$ & $\begin{array}{l}\sqrt{ } \\
\sqrt{ } \\
\sqrt{ } \\
\sqrt{ }\end{array}$ & $\begin{array}{l}- \\
- \\
-\end{array}$ \\
\hline $70 R$ & $\begin{array}{l}02 / 10 / 08 \\
04 / 05 / 08 \\
10 / 18 / 08\end{array}$ & $\begin{array}{l}345 \\
372 \\
370\end{array}$ & $\begin{array}{l}\sqrt{ } \\
\sqrt{ } \\
\sqrt{ }\end{array}$ & - & - & $\begin{array}{l}\sqrt{ } \\
- \\
\sqrt{ }\end{array}$ & $\begin{array}{l}- \\
-\end{array}$ \\
\hline $81 \mathrm{~L}$ & $\begin{array}{l}02 / 11 / 08 \\
04 / 06 / 08 \\
05 / 25 / 08 \\
09 / 26 / 08\end{array}$ & $\begin{array}{l}303 \\
293 \\
405 \\
362\end{array}$ & $\begin{array}{l}\sqrt{ } \\
\sqrt{ } \\
\sqrt{ } \\
\sqrt{ }\end{array}$ & $\begin{array}{l}- \\
- \\
-\end{array}$ & $\begin{array}{l}\sqrt{ } \\
\sqrt{ } \\
- \\
\sqrt{ }\end{array}$ & $\begin{array}{l}\sqrt{ } \\
\sqrt{ } \\
\sqrt{ }\end{array}$ & $\begin{array}{l}- \\
-\end{array}$ \\
\hline
\end{tabular}


Appendix A. Summary of study sites and types of data collected, Colorado River in Marble and Grand Canyons

Appendix A. Summary of study sites and types of data collected, Colorado River in Marble and Grand Canyons. - Continued

[Site ID is river mile (RM) location based on the RM centerline (U.S. Geological Survey, 2006) downstream from Lees Ferry (river mile 0) in Grand Canyon National Park. The descriptors "L" and "R" denote the location of the emergent sandbar on left and right sides of the river, respectively, facing downstream. Date of study is that of topographic survey (month/day/year). Discharges were estimated from the water surface during topographic surveys using the stage-discharge relations of Hazel and others (2006b). $\sqrt{ }$, data were collected. -, no data were collected or data were not recoverable.]

\begin{tabular}{|c|c|c|c|c|c|c|c|}
\hline $\begin{array}{l}\text { Site } \\
\text { ID }\end{array}$ & Date & $\begin{array}{l}\text { Discharge } \\
\left(\mathrm{m}^{3} / \mathrm{s}\right)\end{array}$ & $\begin{array}{c}\text { Topographic } \\
\text { survey }\end{array}$ & $\begin{array}{c}\text { Bathymetric } \\
\text { survey }\end{array}$ & $\begin{array}{l}\text { Campsite } \\
\text { survey }\end{array}$ & $\begin{array}{l}\text { Time-lapse } \\
\text { photography }\end{array}$ & $\begin{array}{l}\text { Scour } \\
\text { chains }\end{array}$ \\
\hline \multirow{3}{*}{$84 \mathrm{R}$} & 02/11/08 & 309 & $\sqrt{ }$ & - & $\sqrt{ }$ & - & - \\
\hline & 04/06/08 & 279 & $\sqrt{ }$ & - & $\sqrt{ }$ & - & \multirow{2}{*}{$\begin{array}{l}- \\
-\end{array}$} \\
\hline & $09 / 27 / 08$ & 353 & $\sqrt{ }$ & - & - & - & \\
\hline \multirow{3}{*}{ 87L } & 02/11/08 & 334 & $\sqrt{ }$ & $\sqrt{ }$ & $\sqrt{ }$ & $\sqrt{ }$ & - \\
\hline & 04/06/08 & 329 & $\sqrt{ }$ & $\sqrt{ }$ & $\sqrt{ }$ & $\sqrt{ }$ & - \\
\hline & 10/19/08 & 368 & $\sqrt{ }$ & - & - & $\sqrt{ }$ & - \\
\hline \multirow{3}{*}{$88 R$} & 02/11/08 & 327 & $\sqrt{ }$ & $\sqrt{ }$ & - & - & - \\
\hline & 04/06/08 & 300 & $\sqrt{ }$ & $\sqrt{ }$ & - & - & - \\
\hline & $10 / 19 / 08$ & 337 & $\sqrt{ }$ & - & - & - & - \\
\hline \multirow{3}{*}{ 91R } & $02 / 12 / 08$ & 346 & $\sqrt{ }$ & - & - & $\sqrt{ }$ & - \\
\hline & $04 / 07 / 08$ & 280 & $\sqrt{ }$ & - & - & $\sqrt{ }$ & - \\
\hline & $10 / 19 / 08$ & 372 & $\sqrt{ }$ & - & - & $\sqrt{ }$ & - \\
\hline \multirow{3}{*}{ 93L } & $02 / 12 / 08$ & 322 & $\sqrt{ }$ & $\sqrt{ }$ & $\sqrt{ }$ & - & - \\
\hline & 04/07/08 & 276 & $\sqrt{ }$ & $\sqrt{ }$ & $\sqrt{ }$ & - & - \\
\hline & $10 / 20 / 08$ & 360 & $\sqrt{ }$ & - & $\sqrt{ }$ & - & - \\
\hline \multirow{3}{*}{ 104R } & $02 / 12 / 08$ & 323 & $\sqrt{ }$ & $\sqrt{ }$ & $\sqrt{ }$ & $\sqrt{ }$ & - \\
\hline & $04 / 07 / 08$ & 303 & $\sqrt{ }$ & $\sqrt{ }$ & $\sqrt{ }$ & $\sqrt{ }$ & - \\
\hline & $10 / 20 / 08$ & 360 & $\sqrt{ }$ & - & $\sqrt{ }$ & $\sqrt{ }$ & - \\
\hline \multirow{3}{*}{$119.4 r$} & $02 / 12 / 08$ & 319 & $\sqrt{ }$ & $\sqrt{ }$ & $\sqrt{ }$ & $\sqrt{ }$ & $\sqrt{ }$ \\
\hline & $04 / 08 / 08$ & 299 & $\sqrt{ }$ & $\sqrt{ }$ & $\sqrt{ }$ & $\sqrt{ }$ & - \\
\hline & $10 / 21 / 08$ & 372 & $\sqrt{ }$ & - & $\sqrt{ }$ & $\sqrt{ }$ & - \\
\hline \multirow{4}{*}{$119.8 \mathrm{r}$} & $02 / 12 / 08$ & 317 & $\sqrt{ }$ & $\sqrt{ }$ & - & - & - \\
\hline & $04 / 08 / 08$ & 318 & $\sqrt{ }$ & $\sqrt{ }$ & - & - & - \\
\hline & 05/27/08 & 386 & $\sqrt{ }$ & - & - & - & - \\
\hline & $10 / 21 / 08$ & 368 & $\sqrt{ }$ & - & - & - & - \\
\hline \multirow{4}{*}{$122 \mathrm{R}$} & $02 / 12 / 08$ & 343 & $\sqrt{ }$ & $\sqrt{ }$ & $\sqrt{ }$ & $\sqrt{ }$ & $\sqrt{ }$ \\
\hline & $04 / 08 / 08$ & 337 & $\sqrt{ }$ & $\sqrt{ }$ & $\sqrt{ }$ & $\sqrt{ }$ & - \\
\hline & 05/27/08 & 411 & $\sqrt{ }$ & - & - & $\sqrt{ }$ & - \\
\hline & $10 / 21 / 08$ & 363 & $\sqrt{ }$ & - & $\sqrt{ }$ & $\sqrt{ }$ & - \\
\hline \multirow{4}{*}{$123 \mathrm{~L}$} & $02 / 13 / 08$ & 358 & $\sqrt{ }$ & $\sqrt{ }$ & $\sqrt{ }$ & $\sqrt{ }$ & - \\
\hline & $04 / 08 / 08$ & 286 & $\sqrt{ }$ & $\sqrt{ }$ & $\sqrt{ }$ & $\sqrt{ }$ & - \\
\hline & 05/28/08 & 360 & $\sqrt{ }$ & - & - & $\sqrt{ }$ & - \\
\hline & $10 / 21 / 08$ & 376 & $\sqrt{ }$ & - & $\sqrt{ }$ & $\sqrt{ }$ & - \\
\hline \multirow{3}{*}{$137 \mathrm{~L}$} & 02/13/08 & 336 & $\sqrt{ }$ & $\sqrt{ }$ & $\sqrt{ }$ & $\sqrt{ }$ & - \\
\hline & 04/09/08 & 284 & $\sqrt{ }$ & $\sqrt{ }$ & $\sqrt{ }$ & $\sqrt{ }$ & - \\
\hline & $10 / 22 / 08$ & 362 & $\sqrt{ }$ & - & $\sqrt{ }$ & $\sqrt{ }$ & - \\
\hline
\end{tabular}


Appendix A. Summary of study sites and types of data collected, Colorado River in Marble and Grand Canyons. —Continued

[Site ID is river mile (RM) location based on the RM centerline (U.S. Geological Survey, 2006) downstream from Lees Ferry (river mile 0) in Grand Canyon National Park. The descriptors "L" and "R" denote the location of the emergent sandbar on left and right sides of the river, respectively, facing downstream. Date of study is that of topographic survey (month/day/year). Discharges were estimated from the water surface during topographic surveys using the stage-discharge relations of Hazel and others (2006b). V, data were collected. -, no data were collected or data were not recoverable.]

\begin{tabular}{|c|c|c|c|c|c|c|c|}
\hline $\begin{array}{l}\text { Site } \\
\text { ID }\end{array}$ & Date & $\begin{array}{c}\text { Discharge } \\
\left(\mathrm{m}^{3} / \mathrm{s}\right)\end{array}$ & $\begin{array}{l}\text { Topographic } \\
\text { survey }\end{array}$ & $\begin{array}{c}\text { Bathymetric } \\
\text { survey }\end{array}$ & $\begin{array}{c}\text { Campsite } \\
\text { survey }\end{array}$ & $\begin{array}{l}\text { Time-lapse } \\
\text { photography }\end{array}$ & $\begin{array}{l}\text { Scour } \\
\text { chains }\end{array}$ \\
\hline \multirow{3}{*}{$139 \mathrm{R}$} & $02 / 13 / 08$ & 346 & $\sqrt{ }$ & $\sqrt{ }$ & $\sqrt{ }$ & $\sqrt{ }$ & - \\
\hline & 04/09/08 & 299 & $\sqrt{ }$ & $\sqrt{ }$ & $\sqrt{ }$ & $\sqrt{ }$ & - \\
\hline & $10 / 22 / 08$ & 380 & $\sqrt{ }$ & - & $\sqrt{ }$ & $\sqrt{ }$ & - \\
\hline \multirow{4}{*}{$145 \mathrm{~L}$} & $02 / 13 / 08$ & 346 & $\sqrt{ }$ & $\sqrt{ }$ & $\sqrt{ }$ & $\sqrt{ }$ & - \\
\hline & $04 / 09 / 08$ & 327 & $\sqrt{ }$ & $\sqrt{ }$ & $\sqrt{ }$ & $\sqrt{ }$ & - \\
\hline & 05/29/08 & 327 & $\sqrt{ }$ & - & - & $\sqrt{ }$ & - \\
\hline & $10 / 22 / 08$ & 365 & $\sqrt{ }$ & - & $\sqrt{ }$ & $\sqrt{ }$ & - \\
\hline \multirow{4}{*}{$165 R$} & $02 / 14 / 08$ & 351 & $\sqrt{ }$ & $\sqrt{ }$ & - & - & - \\
\hline & 04/10/08 & 325 & $\sqrt{ }$ & $\sqrt{ }$ & - & - & - \\
\hline & 05/29/08 & 329 & $\sqrt{ }$ & - & - & - & - \\
\hline & 09/30/08 & 367 & $\sqrt{ }$ & - & - & - & - \\
\hline \multirow{4}{*}{$166 \mathrm{~L}$} & $02 / 14 / 08$ & 336 & $\sqrt{ }$ & - & $\sqrt{ }$ & - & $\sqrt{ }$ \\
\hline & 04/10/08 & 286 & $\sqrt{ }$ & - & $\sqrt{ }$ & - & - \\
\hline & 05/29/08 & 343 & $\sqrt{ }$ & - & - & - & - \\
\hline & $10 / 23 / 08$ & 340 & $\sqrt{ }$ & - & $\sqrt{ }$ & - & - \\
\hline \multirow{4}{*}{$172 \mathrm{~L}$} & $02 / 14 / 08$ & 344 & $\sqrt{ }$ & $\sqrt{ }$ & - & $\sqrt{ }$ & $\sqrt{ }$ \\
\hline & 04/10/08 & 297 & $\sqrt{ }$ & $\sqrt{ }$ & - & $\sqrt{ }$ & - \\
\hline & 05/30/08 & 362 & $\sqrt{ }$ & - & - & $\sqrt{ }$ & - \\
\hline & $10 / 23 / 08$ & 346 & $\sqrt{ }$ & - & - & - & - \\
\hline \multirow{4}{*}{$183 R$} & 02/15/08 & 386 & $\sqrt{ }$ & - & $\sqrt{ }$ & $\sqrt{ }$ & - \\
\hline & $04 / 11 / 08$ & 363 & $\sqrt{ }$ & $\sqrt{ }$ & $\sqrt{ }$ & - & - \\
\hline & 05/31/08 & 417 & $\sqrt{ }$ & - & - & $\sqrt{ }$ & - \\
\hline & $10 / 24 / 08$ & 369 & $\sqrt{ }$ & - & $\sqrt{ }$ & - & - \\
\hline \multirow{4}{*}{$194 \mathrm{~L}$} & $02 / 15 / 08$ & 376 & $\sqrt{ }$ & $\sqrt{ }$ & $\sqrt{ }$ & $\sqrt{ }$ & - \\
\hline & 04/11/08 & 349 & $\sqrt{ }$ & $\sqrt{ }$ & $\sqrt{ }$ & $\sqrt{ }$ & - \\
\hline & 05/31/08 & 377 & $\sqrt{ }$ & - & - & $\sqrt{ }$ & - \\
\hline & $10 / 24 / 08$ & 363 & $\sqrt{ }$ & - & $\sqrt{ }$ & $\sqrt{ }$ & - \\
\hline
\end{tabular}


Appendix A. Summary of study sites and types of data collected, Colorado River in Marble and Grand Canyons

Appendix A. Summary of study sites and types of data collected, Colorado River in Marble and Grand Canyons. - Continued

[Site ID is river mile (RM) location based on the RM centerline (U.S. Geological Survey, 2006) downstream from Lees Ferry (river mile 0) in Grand Canyon National Park. The descriptors " $L$ " and "R" denote the location of the emergent sandbar on left and right sides of the river, respectively, facing downstream. Date of study is that of topographic survey (month/day/year). Discharges were estimated from the water surface during topographic surveys using the stage-discharge relations of Hazel and others (2006b). V, data were collected. -, no data were collected or data were not recoverable.]

\begin{tabular}{|c|c|c|c|c|c|c|c|}
\hline $\begin{array}{l}\text { Site } \\
\text { ID }\end{array}$ & Date & $\begin{array}{l}\text { Discharge } \\
\left(\mathrm{m}^{3} / \mathrm{s}\right)\end{array}$ & $\begin{array}{c}\text { Topographic } \\
\text { survey }\end{array}$ & $\begin{array}{c}\text { Bathymetric } \\
\text { survey }\end{array}$ & $\begin{array}{c}\text { Campsite } \\
\text { survey }\end{array}$ & $\begin{array}{l}\text { Time-lapse } \\
\text { photography }\end{array}$ & $\begin{array}{l}\text { Scour } \\
\text { chains }\end{array}$ \\
\hline \multirow{4}{*}{ 201R } & 02/16/08 & 371 & $\sqrt{ }$ & $\sqrt{ }$ & - & - & - \\
\hline & $04 / 11 / 08$ & 366 & $\sqrt{ }$ & $\sqrt{ }$ & - & - & - \\
\hline & 06/01/08 & 405 & $\sqrt{ }$ & - & - & - & - \\
\hline & $10 / 25 / 08$ & 369 & $\sqrt{ }$ & - & - & - & - \\
\hline \multirow{4}{*}{$202 R$} & 02/16/08 & 381 & $\sqrt{ }$ & $\sqrt{ }$ & $\sqrt{ }$ & $\sqrt{ }$ & - \\
\hline & $04 / 11 / 08$ & 322 & $\sqrt{ }$ & $\sqrt{ }$ & $\sqrt{ }$ & $\sqrt{ }$ & - \\
\hline & 06/01/08 & 418 & $\sqrt{ }$ & - & - & $\sqrt{ }$ & - \\
\hline & $10 / 25 / 08$ & 366 & $\sqrt{ }$ & - & $\sqrt{ }$ & $\sqrt{ }$ & - \\
\hline \multirow{4}{*}{$213 L$} & $02 / 17 / 08$ & 344 & $\sqrt{ }$ & $\sqrt{ }$ & $\sqrt{ }$ & $\sqrt{ }$ & - \\
\hline & $04 / 12 / 08$ & 338 & $\sqrt{ }$ & $\sqrt{ }$ & $\sqrt{ }$ & $\sqrt{ }$ & - \\
\hline & $06 / 02 / 08$ & 433 & $\sqrt{ }$ & - & - & - & - \\
\hline & $10 / 26 / 08$ & 362 & $\sqrt{ }$ & - & $\sqrt{ }$ & $\sqrt{ }$ & - \\
\hline \multirow{4}{*}{$214 R$} & $02 / 17 / 08$ & 363 & $\sqrt{ }$ & $\sqrt{ }$ & - & - & - \\
\hline & 04/12/08 & 343 & $\sqrt{ }$ & $\sqrt{ }$ & - & - & - \\
\hline & 06/02/08 & 453 & $\sqrt{ }$ & - & - & - & - \\
\hline & $10 / 26 / 08$ & 374 & $\sqrt{ }$ & - & - & - & - \\
\hline \multirow{3}{*}{$220 R$} & $02 / 17 / 08$ & 449 & $\sqrt{ }$ & $\sqrt{ }$ & $\sqrt{ }$ & - & - \\
\hline & $04 / 12 / 08$ & 415 & $\sqrt{ }$ & $\sqrt{ }$ & $\sqrt{ }$ & - & - \\
\hline & $10 / 26 / 08$ & 438 & $\sqrt{ }$ & - & $\sqrt{ }$ & - & - \\
\hline \multirow{4}{*}{$225 R$} & 02/18/08 & 372 & $\sqrt{ }$ & $\sqrt{ }$ & - & $\sqrt{ }$ & - \\
\hline & $04 / 13 / 08$ & 328 & $\sqrt{ }$ & $\sqrt{ }$ & - & $\sqrt{ }$ & - \\
\hline & 06/03/08 & 391 & $\sqrt{ }$ & - & - & - & - \\
\hline & $10 / 26 / 08$ & 364 & $\sqrt{ }$ & - & - & $\sqrt{ }$ & - \\
\hline
\end{tabular}




\section{Appendix B. Basic Data Tables for Studied Sites on Colorado River, Marble and Grand Canyons}

Table B1. High-elevation-zone area and volume at four measurement times in 2008 at each study site.

[Site ID is river mile (RM) location based on the RM centerline (U.S. Geological Survey, 2006) downstream from Lees Ferry (river mile 0) in Grand Canyon National Park. The descriptors "L" and "R" denote the location of the emergent sandbar on left and right sides of the river, respectively, facing downstream. -, indicates no data were collected or data were not recoverable.]

\begin{tabular}{|c|c|c|c|c|c|c|c|c|}
\hline \multirow{2}{*}{ Site ID } & \multicolumn{4}{|c|}{$\begin{array}{l}\text { Area } \\
\left(\mathrm{m}^{2}\right)\end{array}$} & \multicolumn{4}{|c|}{$\begin{array}{l}\text { Volume } \\
\left(\mathrm{m}^{3}\right)\end{array}$} \\
\hline & February & April & May & October & February & April & May & October \\
\hline $1 \mathrm{R}$ & 901 & 960 & 961 & 999 & 817 & 845 & 842 & 843 \\
\hline $3 \mathrm{~L}$ & 161 & 170 & 165 & 163 & 103 & 107 & 108 & 109 \\
\hline $8 \mathrm{~L}$ & 781 & 841 & - & 802 & 420 & 432 & - & 395 \\
\hline $9 \mathrm{~L}$ & 430 & 1,267 & 1,121 & 807 & 183 & 798 & 669 & 508 \\
\hline $16 \mathrm{~L}$ & 88 & 170 & - & 153 & 32 & 42 & - & 60 \\
\hline $22 \mathrm{R}$ & 724 & 848 & 845 & 821 & 900 & 1,241 & 1,203 & 1,205 \\
\hline $24 \mathrm{~L}$ & 117 & 152 & - & 149 & 17 & 26 & - & 24 \\
\hline $29 \mathrm{~L}$ & 416 & 691 & - & 538 & 369 & 472 & - & 381 \\
\hline $30 \mathrm{R}$ & 598 & 1,131 & 1,095 & 808 & 641 & 1,077 & 1,041 & 794 \\
\hline $32 \mathrm{R}$ & 725 & 773 & - & 745 & 656 & 623 & - & 598 \\
\hline $33 \mathrm{~L}$ & 3,291 & 3,364 & - & 3,299 & 9,876 & 9,964 & - & 9,791 \\
\hline $35 \mathrm{~L}$ & 838 & 918 & - & 895 & 1,047 & 1,085 & - & 1,079 \\
\hline $41 \mathrm{R}$ & 3,886 & 6,083 & - & 5,833 & 3,600 & 4,964 & - & 5,515 \\
\hline $43 \mathrm{~L}$ & 2,520 & 2,583 & 2,567 & 2,645 & 2,818 & 2,882 & 2,865 & 2,984 \\
\hline $44 \mathrm{~L}$ & 3,192 & 4,239 & 4,239 & 3,914 & 3,775 & 4,721 & 4,721 & 4,460 \\
\hline $45 \mathrm{~L}$ & 1,937 & 3,455 & 3,455 & 2,878 & 2,871 & 3,778 & 3,778 & 3,593 \\
\hline $47 R$ & 1,022 & 2,130 & 2,010 & 1,623 & 707 & 1,222 & 1,220 & 1,090 \\
\hline $49 \mathrm{R}$ & 909 & 2,279 & 1,955 & 1,524 & 926 & 2,037 & 1,942 & 1,656 \\
\hline $49 \mathrm{~L}$ & 1,394 & 1,674 & 1,660 & 1,656 & 1,343 & 1,863 & 1,835 & 1,875 \\
\hline $50 \mathrm{R}$ & 1,935 & 2,066 & 2,066 & 1,979 & 3,285 & 3,270 & 3,270 & 3,346 \\
\hline $51 \mathrm{~L}$ & 6,002 & 6,194 & 6,182 & 6,189 & 5,585 & 6,070 & 6,038 & 6,056 \\
\hline $54 \mathrm{R}$ & 760 & 1,328 & - & 1,270 & 424 & 655 & - & 781 \\
\hline $55 \mathrm{R}$ & 6,004 & 6,659 & 6,608 & 6,558 & 3,879 & 4,424 & 4,555 & 4,276 \\
\hline $56 \mathrm{R}$ & 1,565 & 2,148 & 2,073 & 2,068 & 1,175 & 1,240 & 1,247 & 1,288 \\
\hline $58 \mathrm{~L}$ & 3,141 & 3,608 & 3,621 & 3,635 & 4,198 & 5,007 & 4,945 & 5,049 \\
\hline $62 \mathrm{R}$ & 350 & 382 & - & 397 & 203 & 315 & - & 299 \\
\hline $63 \mathrm{~L}$ & 256 & 714 & 714 & 736 & 121 & 295 & 295 & 316 \\
\hline $65 \mathrm{R}$ & 797 & 4,085 & 4,085 & 1,263 & 625 & 2,897 & 2,897 & 714 \\
\hline $65 \mathrm{~L}$ & 324 & 1,589 & 1,630 & 1,651 & 105 & 717 & 899 & 735 \\
\hline $66 \mathrm{~L}$ & 114 & 3,174 & 2,468 & 682 & 33 & 488 & 313 & 58 \\
\hline $68 \mathrm{R}$ & 2,347 & 3,294 & 2,912 & 2,856 & 1,276 & 1,733 & 1,776 & 1,834 \\
\hline 70R & 746 & 1,502 & - & 1,126 & 519 & 1,502 & - & 951 \\
\hline $81 \mathrm{~L}$ & 1,103 & 1,558 & 1,491 & 1,445 & 867 & 1,341 & 1,239 & 1,162 \\
\hline 84R & 252 & 301 & - & 286 & 363 & 448 & - & 432 \\
\hline $87 \mathrm{~L}$ & 344 & 369 & - & 362 & 309 & 390 & - & 376 \\
\hline $88 \mathrm{R}$ & 212 & 365 & - & 302 & 138 & 266 & - & 218 \\
\hline
\end{tabular}


Table B1. High-elevation-zone area and volume at four measurement times in 2008 at each study site.-Continued

[Site ID is river mile (RM) location based on the RM centerline (U.S. Geological Survey, 2006) downstream from Lees Ferry (river mile 0) in Grand Canyon National Park. The descriptors " $L$ " and "R" denote the location of the emergent sandbar on left and right sides of the river, respectively, facing downstream. -, indicates no data were collected or data were not recoverable.]

\begin{tabular}{|c|c|c|c|c|c|c|c|c|}
\hline \multirow{2}{*}{ Site ID } & \multicolumn{4}{|c|}{$\begin{array}{c}\text { Area } \\
\left(\mathbf{m}^{2}\right)\end{array}$} & \multicolumn{4}{|c|}{$\begin{array}{c}\text { Volume } \\
\left(\mathbf{m}^{3}\right)\end{array}$} \\
\hline & February & April & May & October & February & April & May & October \\
\hline $91 \mathrm{R}$ & 550 & 589 & - & 583 & 1,006 & 1,057 & - & 1,048 \\
\hline $93 \mathrm{~L}$ & 1,088 & 1,490 & - & 1,381 & 659 & 1,212 & - & 1,105 \\
\hline 104R & 246 & 312 & - & 265 & 232 & 330 & - & 284 \\
\hline 119R & 1,091 & 1,748 & 1,623 & 1,363 & 1,474 & 2,115 & 2,044 & 1,926 \\
\hline $120 \mathrm{R}$ & 817 & 1,096 & 1,085 & 1,062 & 867 & 1,401 & 1,399 & 1,381 \\
\hline $122 \mathrm{R}$ & 1,324 & 2,164 & 2,086 & 2,093 & 1,187 & 1,769 & 1,779 & 1,783 \\
\hline $123 \mathrm{~L}$ & 1,114 & 1,313 & 1,240 & 1,195 & 2,038 & 2,330 & 2,312 & 2,320 \\
\hline 137L & 684 & 1,006 & - & 726 & 659 & 736 & - & 647 \\
\hline 139R & 432 & 477 & - & 476 & 274 & 382 & - & 378 \\
\hline $145 \mathrm{~L}$ & 448 & 692 & 650 & 575 & 533 & 709 & 656 & 584 \\
\hline $165 \mathrm{R}$ & 280 & 1,165 & 1,123 & 1,081 & 100 & 700 & 684 & 677 \\
\hline $166 \mathrm{~L}$ & 2,386 & 2,938 & 2,820 & 2,513 & 2,792 & 3,235 & 3,201 & 3,368 \\
\hline $172 \mathrm{~L}$ & 1,593 & 2,825 & 2,763 & 2,759 & 1,364 & 2,388 & 2,322 & 2,266 \\
\hline $183 \mathrm{~L}$ & 1,210 & 1,413 & 1,313 & 1,278 & 2,380 & 2,690 & 2,646 & 2,620 \\
\hline 194R & 5,633 & 6,140 & 6,157 & 6,029 & 5,755 & 7,165 & 7,170 & 7,008 \\
\hline 201R & 208 & 2,134 & 1,838 & 987 & 70 & 1,149 & 1,116 & 799 \\
\hline 202R & 1,007 & 1,508 & 1,308 & 1,205 & 673 & 1,116 & 1,115 & 1,064 \\
\hline $213 \mathrm{~L}$ & 665 & 1,212 & 1,071 & 968 & 638 & 1,476 & 1,436 & 1,330 \\
\hline $214 \mathrm{R}$ & 232 & 198 & 196 & 187 & 161 & 144 & 143 & 134 \\
\hline $\begin{array}{l}220 R \\
225 R\end{array}$ & $\begin{array}{l}1,338 \\
1,443\end{array}$ & $\begin{array}{l}1,408 \\
1,891\end{array}$ & - & $\begin{array}{l}1,346 \\
1,819\end{array}$ & $\begin{array}{l}1,100 \\
1,076\end{array}$ & $\begin{array}{l}1,332 \\
1,608\end{array}$ & - & $\begin{array}{l}1,287 \\
1,585\end{array}$ \\
\hline
\end{tabular}


Table B2. Midelevation zone area and volume at four measurement times in 2008 at each study site.

[Site ID is river mile (RM) location based on the RM centerline (U.S. Geological Survey, 2006) downstream from Lees Ferry (river mile 0) in Grand Canyon National Park. The descriptors "L" and "R" denote the location of the emergent sandbar on left and right sides of the river, respectively, facing downstream. -, indicates no data were collected or data were not recoverable.]

\begin{tabular}{|c|c|c|c|c|c|c|c|c|}
\hline \multirow{2}{*}{ Site ID } & \multicolumn{4}{|c|}{$\begin{array}{l}\text { Area } \\
\left(\mathrm{m}^{2}\right)\end{array}$} & \multicolumn{4}{|c|}{$\begin{array}{c}\text { Volume } \\
\left(\mathrm{m}^{3}\right)\end{array}$} \\
\hline & February & April & May & October & February & April & May & October \\
\hline $1 \mathrm{R}$ & 7,361 & 12,164 & 11,744 & 10,468 & 7,507 & 7,752 & 9,608 & 8,576 \\
\hline $3 \mathrm{~L}$ & 2,297 & 754 & 588 & 598 & 2,143 & 978 & 838 & 765 \\
\hline $8 \mathrm{~L}$ & 1,361 & 1,515 & - & 1,377 & 2,278 & 2,883 & - & 2,594 \\
\hline 9L & 3,417 & 2,383 & 2,429 & 2,045 & 4,841 & 6,838 & 6,150 & 4,537 \\
\hline $16 \mathrm{~L}$ & 1,351 & 970 & - & 1,088 & 1,099 & 1,546 & - & 1,410 \\
\hline $22 \mathrm{R}$ & 1,962 & 1,701 & 1,677 & 1,283 & 5,148 & 5,698 & 5,321 & 4,831 \\
\hline $24 \mathrm{~L}$ & 2,007 & 2,048 & - & 2,197 & 3,266 & 3,862 & - & 3,877 \\
\hline $29 \mathrm{~L}$ & 1,208 & 1,774 & - & 1,758 & 2,529 & 4,970 & - & 4,296 \\
\hline $30 \mathrm{R}$ & 1,750 & 2,116 & 2,470 & 2,007 & 3,448 & 6,638 & 6,312 & 4,732 \\
\hline $32 \mathrm{R}$ & 2,748 & 2,471 & - & 2,317 & 3,014 & 3,504 & - & 3,198 \\
\hline 33L & 656 & 924 & - & 552 & 9,360 & 9,811 & - & 9,265 \\
\hline $35 \mathrm{~L}$ & 1,450 & 1,220 & - & 1,047 & 7,922 & 9,096 & - & 7,930 \\
\hline $41 \mathrm{R}$ & 12,118 & 10,040 & - & 8,586 & 20,326 & 26,560 & - & 23,536 \\
\hline 43L & 1,401 & 1,206 & 1,218 & 1,175 & 7,910 & 7,966 & 7,989 & 7,989 \\
\hline $44 \mathrm{~L}$ & 6,225 & 5,970 & - & 6,562 & 12,068 & 14,522 & - & 12,820 \\
\hline $45 \mathrm{~L}$ & 2,214 & 3,316 & 2,483 & 2,842 & 5,888 & 11,778 & 10,002 & 8,760 \\
\hline $47 \mathrm{R}$ & 2,581 & 3,906 & 3,241 & 3,323 & 4,841 & 8,762 & 7,443 & 5,993 \\
\hline 49R & 2,248 & 1,147 & 558 & 1,211 & 2,746 & 4,891 & 3,831 & 3,347 \\
\hline 49L & 2,472 & 1,053 & 1,006 & 1,817 & 3,797 & 3,781 & 3,687 & 3,903 \\
\hline $50 \mathrm{R}$ & 2,141 & 1,711 & 2,026 & 1,446 & 6,439 & 6,532 & 6,386 & 5,894 \\
\hline $51 \mathrm{~L}$ & 6,237 & 2,173 & 1,968 & 2,462 & 18,483 & 16,097 & 15,975 & 16,096 \\
\hline $54 \mathrm{R}$ & 3,312 & 1,323 & - & 3,109 & 3,821 & 3,770 & - & 4,826 \\
\hline $55 \mathrm{R}$ & 8,269 & 4,374 & 4,497 & 5,476 & 14,877 & 14,385 & 14,251 & 14,455 \\
\hline $56 \mathrm{R}$ & 2,507 & 1,433 & 1,700 & 2,095 & 3,582 & 4,830 & 4,700 & 4,765 \\
\hline $58 \mathrm{~L}$ & 2,401 & 2,179 & 3,015 & 2,394 & 8,817 & 10,409 & 10,619 & 10,021 \\
\hline $62 \mathrm{R}$ & 716 & 687 & - & 692 & 1,407 & 1,428 & - & 1,443 \\
\hline $63 \mathrm{~L}$ & 4,978 & 5,856 & 4,290 & 4,697 & 5,215 & 10,000 & 8,105 & 7,102 \\
\hline $65 \mathrm{R}$ & 6,705 & 4,271 & 3,160 & 3,759 & 4,525 & 12,425 & 8,365 & 4,239 \\
\hline $65 \mathrm{~L}$ & 5,901 & 2,335 & 2,745 & 3,363 & 5,346 & 4,636 & 4,800 & 5,242 \\
\hline $66 \mathrm{~L}$ & 5,134 & 4,389 & 4,067 & 4,121 & 1,873 & 7,990 & 6,637 & 3,927 \\
\hline $68 \mathrm{R}$ & 2,280 & 2,657 & 1,702 & 1,657 & 5,135 & 7,069 & 5,672 & 5,433 \\
\hline $70 \mathrm{R}$ & 607 & 1,602 & - & 1,764 & 1,955 & 1,602 & - & 2,953 \\
\hline $81 \mathrm{~L}$ & 951 & 550 & 609 & 650 & 3,564 & 4,054 & 3,935 & 3,835 \\
\hline $84 \mathrm{R}$ & 830 & 636 & - & 743 & 1,462 & 1,390 & - & 1,340 \\
\hline $87 \mathrm{~L}$ & 493 & 333 & - & 366 & 1,605 & 1,390 & - & 1,450 \\
\hline 88R & 1,455 & 1,174 & - & 1,252 & 1,660 & 1,841 & - & 1,689 \\
\hline 91R & 872 & 511 & - & 407 & 2,261 & 1,920 & - & 1,818 \\
\hline 93L & 1,221 & 624 & - & 601 & 3,220 & 3,197 & - & 2,943 \\
\hline 104R & 201 & 236 & - & 277 & 844 & 1,028 & - & 893 \\
\hline $119 \mathrm{R}$ & 2,280 & 1,762 & 1,588 & 1,447 & 4,989 & 7,200 & 6,245 & 5,235 \\
\hline 120R & 2,086 & 1,219 & 1,341 & 1,306 & 4,038 & 4,175 & 4,063 & 3,770 \\
\hline $122 \mathrm{R}$ & 2,739 & 1,804 & 2,614 & 2,246 & 6,492 & 7,899 & 8,054 & 7,613 \\
\hline
\end{tabular}


Table B2. Midelevation zone area and volume at four measurement times in 2008 at each study site.—Continued

[Site ID is river mile (RM) location based on the RM centerline (U.S. Geological Survey, 2006) downstream from Lees Ferry (river mile 0) in Grand Canyon National Park. The descriptors "L" and "R" denote the location of the emergent sandbar on left and right sides of the river, respectively, facing downstream. -, indicates no data were collected or data were not recoverable.]

\begin{tabular}{|c|c|c|c|c|c|c|c|c|}
\hline \multirow{2}{*}{ Site ID } & \multicolumn{4}{|c|}{$\begin{array}{l}\text { Area } \\
\left(\mathrm{m}^{2}\right)\end{array}$} & \multicolumn{4}{|c|}{$\begin{array}{c}\text { Volume } \\
\left(\mathrm{m}^{3}\right)\end{array}$} \\
\hline & February & April & May & October & February & April & May & October \\
\hline $123 \mathrm{~L}$ & 1,755 & 664 & 713 & 1,256 & 4,343 & 3,646 & 3,403 & 3,850 \\
\hline $137 \mathrm{~L}$ & 2,845 & 2,045 & - & 2,742 & 4,710 & 5,671 & - & 5,156 \\
\hline $139 \mathrm{R}$ & 1,506 & 839 & - & 1,136 & 2,884 & 2,327 & - & 2,665 \\
\hline $145 \mathrm{~L}$ & 492 & 265 & - & 358 & 1,916 & 2,268 & - & 2,029 \\
\hline $165 \mathrm{R}$ & 3,695 & 1,510 & 1,576 & 2,669 & 7,318 & 7,018 & 6,920 & 7,728 \\
\hline $166 \mathrm{~L}$ & 1,877 & 1,296 & 1,429 & 1,715 & 6,612 & 7,021 & 6,787 & 6,556 \\
\hline $172 \mathrm{~L}$ & 2,643 & 1,457 & 1,767 & 1,559 & 6,492 & 7,756 & 7,662 & 7,330 \\
\hline $183 \mathrm{~L}$ & 1,333 & 718 & 860 & 1,647 & 4,206 & 4,391 & 4,036 & 4,390 \\
\hline $194 R$ & 2,865 & 2,408 & 2,305 & 2,661 & 15,081 & 15,967 & 15,706 & 15,631 \\
\hline $201 R$ & 3,315 & 2,888 & 2,846 & 3,300 & 2,677 & 9,258 & 6,612 & 4,000 \\
\hline $202 \mathrm{R}$ & 1,687 & 882 & 961 & 1,024 & 3,965 & 4,330 & 3,718 & 3,439 \\
\hline $213 \mathrm{~L}$ & 1,356 & 1,029 & 674 & 835 & 5,005 & 6,237 & 5,227 & 4,772 \\
\hline $214 \mathrm{R}$ & 1,757 & 505 & 1,413 & 2,548 & 1,781 & 696 & 1,112 & 1,777 \\
\hline $220 \mathrm{R}$ & 423 & 428 & - & 453 & 2,796 & 2,820 & - & 2,791 \\
\hline $225 \mathrm{R}$ & 1,123 & 649 & - & 878 & 4,516 & 4,742 & - & 4,608 \\
\hline
\end{tabular}


Table B3. Low-elevation-zone eddy area and volume, and main-channel volume at four measurement times in 2008 at each study site.

[Site ID is river mile (RM) location based on the RM centerline (U.S. Geological Survey, 2006) downstream from Lees Ferry (river mile 0) in Grand Canyon National Park. The descriptors "L" and "R" denote the location of the emergent sandbar on left and right sides of the river, respectively, facing downstream. -, indicates no data were collected or data were not recoverable.]

\begin{tabular}{|c|c|c|c|c|c|c|}
\hline \multirow{3}{*}{ Site ID } & \multicolumn{4}{|c|}{ Low-elevation eddy zone } & \multirow{2}{*}{\multicolumn{2}{|c|}{$\begin{array}{c}\text { Main-channel } \\
\text { Volume } \\
\left(\mathrm{m}^{3}\right)\end{array}$}} \\
\hline & \multicolumn{2}{|c|}{$\begin{array}{c}\text { Area } \\
\left(\mathrm{m}^{2}\right)\end{array}$} & \multicolumn{2}{|c|}{$\begin{array}{c}\text { Volume } \\
\left(\mathrm{m}^{3}\right)\end{array}$} & & \\
\hline & February & April & February & April & February & April \\
\hline $1 \mathrm{R}$ & - & 27,750 & - & 48,246 & - & - \\
\hline $3 \mathrm{~L}$ & 5,148 & 6,683 & 25,818 & 12,665 & 67,587 & 26,320 \\
\hline $8 \mathrm{~L}$ & - & - & - & - & - & - \\
\hline $9 \mathrm{~L}$ & - & 8,618 & - & 3,158 & - & - \\
\hline $16 \mathrm{~L}$ & 6,715 & 7,013 & 16,209 & 9,842 & 12,172 & 8,907 \\
\hline $22 \mathrm{R}$ & 4,462 & 4,599 & 17,590 & 16,389 & 5,245 & 4,854 \\
\hline $24 \mathrm{~L}$ & - & - & - & - & - & - \\
\hline $29 \mathrm{~L}$ & - & - & - & - & - & - \\
\hline $30 \mathrm{R}$ & 6,175 & 5,276 & 10,890 & 12,359 & 7,893 & 8,390 \\
\hline $32 \mathrm{R}$ & 8,152 & 8,381 & 26,762 & 12,398 & 13,216 & 7,014 \\
\hline $33 \mathrm{~L}$ & - & - & - & - & - & - \\
\hline $35 \mathrm{~L}$ & 19,088 & 19,233 & 33,324 & 39,397 & 35,196 & 47,696 \\
\hline $41 \mathrm{R}$ & 26,046 & 25,913 & 27,687 & 24,685 & 7,443 & 7,714 \\
\hline $43 \mathrm{~L}$ & 4,538 & 4,670 & 8,141 & 7,199 & 58,758 & 56,612 \\
\hline $44 \mathrm{~L}$ & 17,147 & 16,351 & 53,466 & 34,263 & 24,379 & 28,442 \\
\hline $45 \mathrm{~L}$ & 18,399 & 15,779 & 16,762 & 17,886 & 4,564 & 7,170 \\
\hline $47 \mathrm{R}$ & 24,835 & 22,402 & 23,350 & 51,026 & 25,630 & 31,591 \\
\hline $49 \mathrm{R}$ & 4,483 & 4,215 & 22,398 & 19,793 & - & - \\
\hline $49 \mathrm{~L}$ & 10,604 & 11,743 & 52,857 & 35,025 & 41,368 & 49,553 \\
\hline $50 \mathrm{R}$ & - & - & - & - & - & - \\
\hline $51 \mathrm{~L}$ & 19,463 & 23,335 & 46,263 & 40,975 & 38,652 & 38,648 \\
\hline $54 \mathrm{R}$ & 8,295 & 9,715 & 15,197 & 9,874 & 22,450 & 27,946 \\
\hline $55 \mathrm{R}$ & 10,072 & 13,314 & 60,244 & 35,847 & 63,334 & 54,769 \\
\hline $56 \mathrm{R}$ & - & - & - & - & - & - \\
\hline $58 \mathrm{~L}$ & - & - & - & - & - & - \\
\hline $62 \mathrm{R}$ & 14,758 & 14,869 & 30,241 & 35,184 & 15,413 & 10,691 \\
\hline $63 \mathrm{~L}$ & 22,610 & 21,294 & 62,432 & 81,323 & 22,941 & 31,147 \\
\hline $65 \mathrm{R}$ & 9,654 & 8,779 & 46,807 & 41,986 & 43,702 & 26,494 \\
\hline $65 \mathrm{~L}$ & 6,069 & 8,371 & 26,564 & 20,761 & 9,367 & 9,350 \\
\hline $66 \mathrm{~L}$ & - & - & - & - & - & - \\
\hline $68 \mathrm{R}$ & 10,500 & 9,176 & 22,300 & 29,374 & 21,605 & 29,095 \\
\hline $70 \mathrm{R}$ & - & - & - & - & - & - \\
\hline $81 \mathrm{~L}$ & - & - & - & - & - & - \\
\hline $84 \mathrm{R}$ & - & - & - & - & - & - \\
\hline $87 \mathrm{~L}$ & 316 & 451 & 625 & 367 & 9,209 & 12,300 \\
\hline $88 \mathrm{R}$ & 1401 & 1511 & 1430 & 966 & 31,008 & 23,296 \\
\hline $91 \mathrm{R}$ & - & - & - & - & - & - \\
\hline $93 \mathrm{~L}$ & 1,285 & 1,479 & 4,303 & 3,838 & 9,339 & 12,265 \\
\hline $104 \mathrm{R}$ & 575 & 474 & 290 & 586 & 1,368 & 1,649 \\
\hline $119 \mathrm{R}$ & 5,558 & 5,419 & 11,788 & 9,929 & 6,805 & 6,315 \\
\hline $120 \mathrm{R}$ & 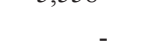 & - & - & - & - & - \\
\hline
\end{tabular}


Table B3. Low-elevation-zone eddy area and volume, and main-channel volume at four measurement times in 2008 at each study site.-Continued

[Site ID is river mile (RM) location based on the RM centerline (U.S. Geological Survey, 2006) downstream from Lees Ferry (river mile 0) in Grand Canyon National Park. The descriptors "L" and "R" denote the location of the emergent sandbar on left and right sides of the river, respectively, facing downstream. -, indicates no data were collected or data were not recoverable.]

\begin{tabular}{|c|c|c|c|c|c|c|}
\hline \multirow{3}{*}{ Site ID } & \multicolumn{4}{|c|}{ Low-elevation eddy zone } & \multirow{2}{*}{\multicolumn{2}{|c|}{$\begin{array}{c}\text { Main-channel } \\
\text { Volume } \\
\left(\mathrm{m}^{3}\right)\end{array}$}} \\
\hline & \multicolumn{2}{|c|}{$\begin{array}{l}\text { Area } \\
\left(\mathrm{m}^{2}\right)\end{array}$} & \multicolumn{2}{|c|}{$\begin{array}{c}\text { Volume } \\
\left(\mathrm{m}^{3}\right)\end{array}$} & & \\
\hline & February & April & February & April & February & April \\
\hline $122 \mathrm{R}$ & 4,178 & 4,273 & 7,521 & 8,222 & 4,798 & 5,363 \\
\hline $123 \mathrm{~L}$ & 5,179 & 6,072 & 13,080 & 5,306 & 17,662 & 10,801 \\
\hline $137 \mathrm{~L}$ & 1,609 & 2,088 & 1,556 & 1,090 & 1,214 & 1,939 \\
\hline $139 \mathrm{R}$ & 5,249 & 5,870 & 12,072 & 7,844 & 6,199 & 8,329 \\
\hline $145 \mathrm{~L}$ & 380 & 363 & 435 & 426 & 2,441 & 2,901 \\
\hline $165 \mathrm{R}$ & 1,180 & 2,479 & 10,857 & 8,704 & 4,345 & 4,679 \\
\hline $166 \mathrm{~L}$ & - & - & - & - & - & - \\
\hline $172 \mathrm{~L}$ & 5,165 & 5,119 & 12,875 & 14,147 & 12,493 & 14,110 \\
\hline $183 \mathrm{~L}$ & - & - & - & - & - & - \\
\hline 194R & 5,638 & 5,590 & 9,880 & 10,980 & 24,944 & 28,775 \\
\hline 201R & 8,533 & 7,035 & 3,432 & 7,890 & 30,702 & 798 \\
\hline $202 R$ & 12,919 & 13,227 & 21,018 & 25,795 & 8,811 & 10,904 \\
\hline $213 \mathrm{~L}$ & 1,973 & 1,753 & 2,407 & 3,783 & 7,734 & 7,967 \\
\hline $214 \mathrm{R}$ & 3,256 & 4,545 & 4,637 & 2,058 & 11,301 & 12,229 \\
\hline $220 \mathrm{R}$ & 688 & 612 & 580 & 841 & - & - \\
\hline 225 & 3,070 & 3,096 & 9,062 & 8,346 & 31,625 & 34,591 \\
\hline
\end{tabular}


Table B4. Midelevation zone and high-elevation-zone campsite area measured at four measurement times in 2008 at each study site.

[Site ID is river mile (RM) location based on the RM centerline (U.S. Geological Survey, 2006) downstream from Lees Ferry (river mile 0 ) in Grand Canyon National Park. The descriptors "L" and "R" denote the location of the emergent sandbar on left and right sides of the river, respectively, facing downstream. -, indicates no data were collected or data were not recoverable. Recreational reaches as defined by Kearsley and Warren (1993); C, critical reach. NC, noncritical reach.]

\begin{tabular}{|c|c|c|c|c|c|c|c|}
\hline \multirow[b]{2}{*}{ Site } & \multirow[b]{2}{*}{$\begin{array}{l}\text { Recreation } \\
\text { Reach }\end{array}$} & \multicolumn{2}{|c|}{ February } & \multicolumn{2}{|c|}{ March } & \multicolumn{2}{|c|}{ October } \\
\hline & & $\begin{array}{l}\text { Midelevation } \\
\qquad\left(\mathrm{m}^{2}\right)\end{array}$ & $\begin{array}{l}\text { High-elevation } \\
\qquad\left(\mathrm{m}^{2}\right)\end{array}$ & $\begin{array}{l}\text { Midelevation } \\
\left(\mathrm{m}^{2}\right)\end{array}$ & $\begin{array}{c}\text { High- } \\
\text { Elevation } \\
\left(\mathrm{m}^{2}\right)\end{array}$ & $\begin{array}{l}\text { Midelevation } \\
\left(\mathrm{m}^{2}\right)\end{array}$ & $\begin{array}{l}\text { High-Elevation } \\
\qquad\left(\mathrm{m}^{2}\right)\end{array}$ \\
\hline $8 \mathrm{~L}$ & $\mathrm{NC}$ & 231 & 300 & 107 & 357 & 387 & 370 \\
\hline $16 \mathrm{~L}$ & $\mathrm{C}$ & 216 & 269 & 363 & 318 & 299 & 273 \\
\hline $22 \mathrm{R}$ & $\mathrm{C}$ & 255 & 130 & 148 & 373 & 102 & 268 \\
\hline $24 \mathrm{~L}$ & $\mathrm{C}$ & 163 & 16 & 699 & 30 & 637 & 35 \\
\hline $29 \mathrm{~L}$ & $\mathrm{C}$ & 102 & 96 & 637 & 288 & 578 & 210 \\
\hline $30 \mathrm{R}$ & $\mathrm{C}$ & 71 & 189 & 397 & 552 & 52 & 267 \\
\hline $32 \mathrm{R}$ & $\mathrm{C}$ & 0 & 372 & 0 & 418 & 0 & 347 \\
\hline $35 \mathrm{~L}$ & $\mathrm{C}$ & 0 & 481 & 79 & 430 & 30 & 490 \\
\hline $41 R$ & $\mathrm{NC}$ & 104 & 229 & 96 & 341 & 36 & 145 \\
\hline $43 \mathrm{~L}$ & $\mathrm{NC}$ & 0 & 184 & 3 & 392 & 0 & 251 \\
\hline $44 \mathrm{~L}$ & $\mathrm{NC}$ & 257 & 576 & 249 & 762 & 175 & 571 \\
\hline $45 \mathrm{~L}$ & $\mathrm{NC}$ & 0 & 263 & 1,148 & 1,140 & 64 & 766 \\
\hline $47 \mathrm{R}$ & $\mathrm{NC}$ & 717 & 384 & 1,837 & 1,092 & 232 & 330 \\
\hline $50 \mathrm{R}$ & $\mathrm{NC}$ & 124 & 593 & 0 & 611 & 45 & 560 \\
\hline $51 \mathrm{~L}$ & $\mathrm{NC}$ & 0 & 110 & 0 & 161 & 0 & 98 \\
\hline $55 \mathrm{R}$ & $\mathrm{NC}$ & 0 & 0 & 0 & 20 & 0 & 0 \\
\hline $62 \mathrm{R}$ & $\mathrm{NC}$ & 0 & 31 & 0 & 135 & 40 & 132 \\
\hline $81 \mathrm{~L}$ & $\mathrm{C}$ & 77 & 391 & 60 & 1,170 & 0 & 853 \\
\hline $84 \mathrm{R}$ & $\mathrm{C}$ & 109 & 82 & 97 & 98 & 65 & 64 \\
\hline $87 \mathrm{~L}$ & $\mathrm{C}$ & 0 & 0 & 0 & 302 & 9 & 206 \\
\hline 91R & $\mathrm{C}$ & 256 & 218 & 0 & 214 & 2 & 197 \\
\hline $93 \mathrm{~L}$ & $\mathrm{C}$ & 88 & 45 & 8 & 325 & 4 & 231 \\
\hline $104 \mathrm{R}$ & $\mathrm{C}$ & 0 & 70 & 6 & 107 & 0 & 76 \\
\hline $119 R$ & $\mathrm{NC}$ & 36 & 137 & 391 & 339 & 132 & 125 \\
\hline $122 \mathrm{R}$ & $\mathrm{NC}$ & 208 & 98 & 299 & 657 & 92 & 719 \\
\hline $123 \mathrm{~L}$ & $\mathrm{NC}$ & 187 & 174 & 0 & 150 & 189 & 89 \\
\hline $137 \mathrm{~L}$ & $\mathrm{C}$ & 380 & 183 & 633 & 581 & 670 & 286 \\
\hline $139 \mathrm{R}$ & $\mathrm{C}$ & 21 & 77 & 0 & 59 & 81 & 63 \\
\hline $145 \mathrm{~L}$ & $\mathrm{C}$ & 9 & 103 & 0 & 394 & 7 & 317 \\
\hline $166 \mathrm{~L}$ & $\mathrm{NC}$ & 70 & 88 & 43 & 128 & 169 & 42 \\
\hline 1721 & $\mathrm{NC}$ & 0 & 0 & 214 & 176 & 0 & 0 \\
\hline $183 \mathrm{~L}$ & $\mathrm{NC}$ & 0 & 0 & 17 & 37 & 0 & 6 \\
\hline $183 R$ & $\mathrm{NC}$ & 107 & 21 & 97 & 330 & 4 & 145 \\
\hline 194R & $\mathrm{NC}$ & 85 & 493 & 0 & 581 & 270 & 317 \\
\hline $202 \mathrm{R}$ & $\mathrm{NC}$ & 498 & 146 & 158 & 598 & 85 & 273 \\
\hline $213 \mathrm{~L}$ & $\mathrm{NC}$ & 238 & 76 & 106 & 444 & 11 & 323 \\
\hline $220 \mathrm{R}$ & $\mathrm{NC}$ & 0 & 461 & 0 & 347 & 0 & 302 \\
\hline sum & & 4,609 & 7,086 & 7,892 & 14,457 & 4,467 & 9,747 \\
\hline median & & 85 & 137 & 79 & 341 & 45 & 251 \\
\hline s.d. & & 157 & 171 & 375 & 293 & 181 & 213 \\
\hline
\end{tabular}


Produced in the Western Region, Menlo Park, California Manuscript approved for publication January 28, 2010

Text edited by Peter Stauffer Layout and design by Judy Weathers 
